Historic, Archive Document

Do not assume content reflects current scientific knowledge, policies, or practices. 



\section{MICHAET}
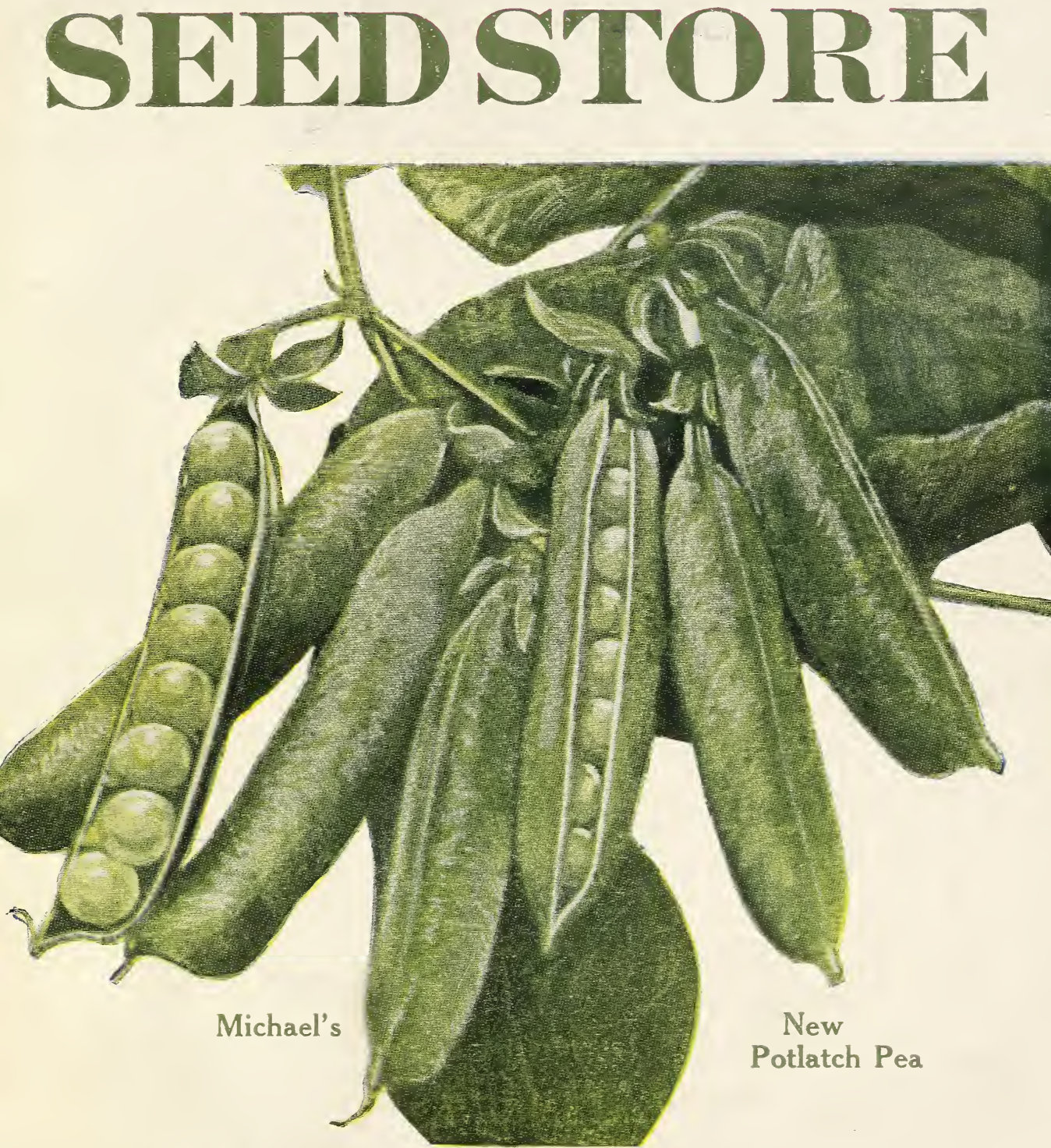

\section{ANNUAL CATALOG \\ 1927}

Sioux City, Iowa 


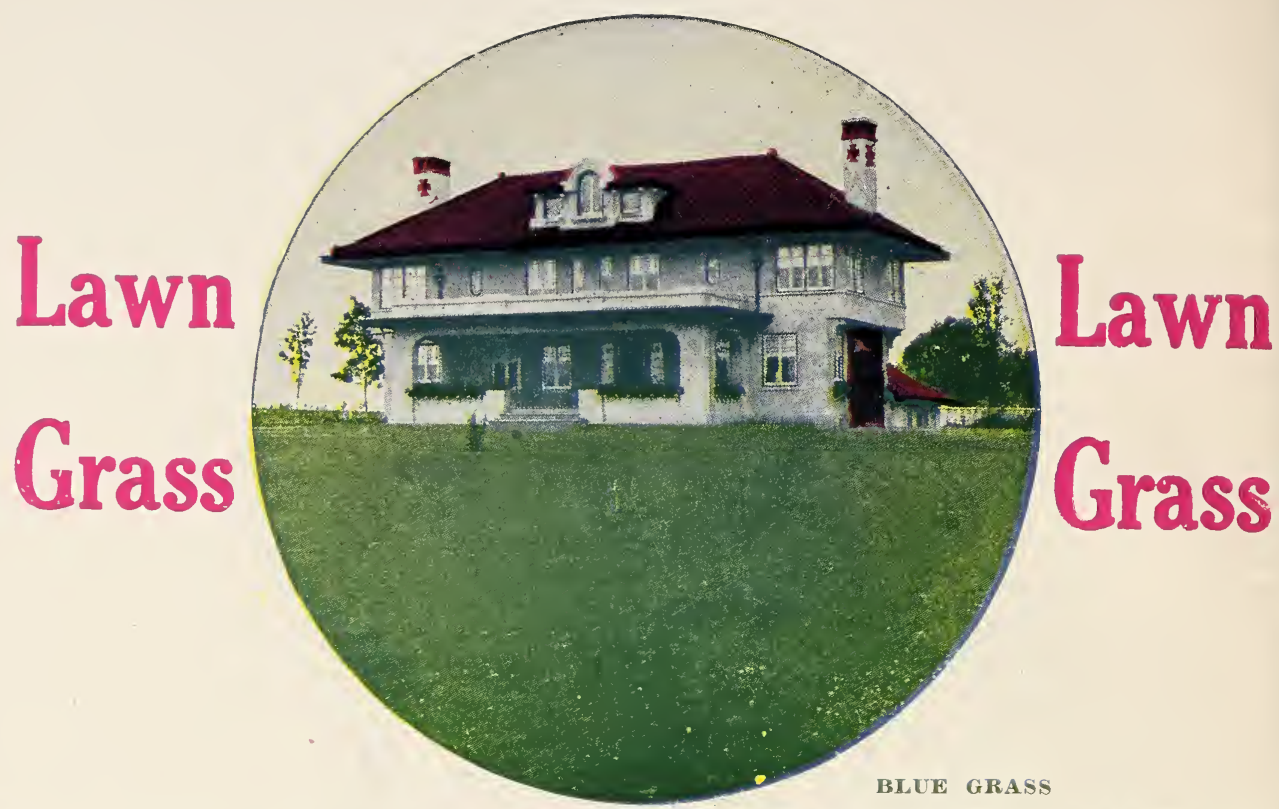

\section{HOW TO MAKE A LAWN}

In preparing a seed bed so as to insure an ever lasting lawn it is well that the earth be stirred deeper than merely scratching the surface, either with a good stirring plow or spade to the depth or a foot or fifteen inches, or even more. This is the first step to be taken, and the next consideration is the fertility of the soil where you are making the lawn. Among the various methods which increase the fertility of the soil we find that Humus plays a most importsnt part. Humus and organic matter such as baru manure, well rotted and pulverized, well mixed in the soil when plowed or spaded, has the effect to keep it sweet and porous. Aside from the fertilizing fea ture, humus increases the capacity of the soil to retain moisture, an important feature in the verdant effect of a velvety lawn. Hydrated Lime can be added to advantage and a coat of this, one hundred pounds to every 1,000 square feet, is highly beneficial and the effect is lasting and permanent. The very best time to do the work of preparing the soil for a lawn is in the autumn season and then left for the winter. The soil is solidified by the winter condition. Then in the spring the surface should be lightly stirred and the seed sown, well raked in and rolled. When the summer is over and the winter comes on again, the lawn needs attention, and it is a wise plan after the ground is slightly frozen to cover it with a moderate coat of well rotted manure. In the springtime before the growth of grass is started, this coat of manure should be well raked in the soil, and the roughage raked off, giving the grass a chance to get plenty of sunlight. Should, however, this be overlooked in the aut. umn, then in the springtime again it is well to apply a moderate amount of sheep manure, phosphate, or ground bone fertilizer, well raked into the soil just as soon as is possible and at such time it is well to apply a sprinkle of our blend of Reseeding Lawn Grass.

These suggestions in regard to the making of a lawn will well repay the time and expense by the increased growth of grass.
The best and most velvety lawn grass is our native grown Kentucky Hlue Grass. It comes earliest in the spring and is the last and freshest green anywhere to be seen in the Autumn until winter comes again. There is sometimes trouble in getting it to come up quick and make a permanent sod, but this is often due perhaps to weather conditions and the quality of seed used. After years of experience we have come to understand and realize the importance and the requisite attention necessary to secure quality in bilue Grass seed. Quality of Blue Grass seed that we are now offering for lawn purposes is a high grade product grown especially for us, extra re-cleaned, sun-dried, highest germination, double weight, all chaff eliminated and in no sense to be compared to the chaffy grades of Blue Grass Seed usually offered for sale. This quality we handle under the name of Purity Brand which when sown on a well prepared seed bed in early spring-time will soon make a well sodded lawn. Purity Brand, 30 1b. quality, limited 75e per 1b.; 20 ib. quality, 50c per 1b.; 51 . bags, \$2.25; 10 lb. bags, \$4.00.

\section{MAGIC IAWN SEED}

This is a special lawn grass of our own blend. It is made up of the best kinds and highest grades of domestic and imported grasses used in lawn work. It comes up quick and grows like magic, giving a continuous green turf through out the season. The soil should be well prepared with a surface of black earth or some well rotted manure mixed in the soil and sown as early in the spring time as you can have the ground prepared. Sow at the rate of one pound to every 500 square feet. Remember that this is our own blend and sold only by ourselves at our Seed Store, 316 Pearl Street. Per 1b. 50c; 5 lbs. $\$ 2.25 ; 101 \mathrm{bg}$. $\$ 4.00$.

\section{RESEEDING IAWN GRASS}

This is a special blend of grasses for reseed ing the lawn after it is well raked and cleaned in the spring time. It has the effect to liven uI an old lawn where the grass shows the effect of age and needs reviving. Sprinkle this seed over the lawn with a liberal application of sheep fertilizer well raked in, early in the spring time, which will bring the desired result. Per lb. 50e; $51 \mathrm{bs}$. $\$ 2.50 ; 101 \mathrm{bs}$. $\$ 4.50$.

DEEP ROOTED LAWN GRASS

This is a blend of strong, powerful rooted grasses. It is especially valuable and is blended on purpose for just such places where we have had trouble to get sod firmly set. Shady nooks, terraces, slopes, sun-baked corners, and other trying places difficult to get a catch and sod started with those velvety foliage surface rooted grasses. In these places Deep Rooted Iawn Grass planted early in the spring time with some good fertilizer well mixed in the soil brings the desired results. Per $1 \mathrm{~b}, 40 \mathrm{c} ; 10 \mathrm{lbs}, \$ 3.50$.

WHITE CLOVER SEED, Superfine quality, 60e per lb.; 5 1b. \$2.50. FERTILIZERS, See Page 48. 


\title{
THE MICHAEL SEED STORE
}

\section{J. S. MICHAEL, Manager}

\author{
Auto Phone 2142 New Phone 935-M \\ 316 Pearl St., SIOUX CITY, IOWA.
}

\section{INDEX}

\section{VEGETABLE SEEDS}

\section{Beans}

Peas

Sweet Corn .................. 4

Beets ...........................

Mangel, Sugar Beets 5 Cabbage ...................5, 6 Cauliflower …............... 5 Carrots ............................. 6

Celery

Cucumber ....................... 7

Lettuce ….................7, 8

Muskmelons ................ 8

Mushroom Spawn .......14

Watermelons .............. 9

Ontons ..........................

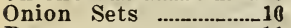

Pepper .............................11

Parsnip ........................12

Pumpkin ......................12

Radish ..........................11

Spinach …..................12

Squash ….........................12

Tomatoes …...................13

Turnips .........................13

Miscellaneous seeds...14

Herb Seeds ..................14

\section{FLOWER SEEDS}

Sweet Peas......................15

Nasturtium .....................15

Aster ..............................16

Zinnia .............................16

Pansy ..............................................

Petunia ...........................17

Perennials ….........

Alphabetical list........ Is

GENERAL LIST

ROOTS, BULBS, PLANTS

Dahlia ............................... Peony ……………...........27 Gladioli Bulbs.............28 Canna Roots.....................28 Hardy Bulb Roots....29 Tender Bulb Roots....29 Iris ........................... 30 Conservatory Plants..30 Autumn Bulbs.............30 Flowering Plants.....31 Vegetable Plants.........31.

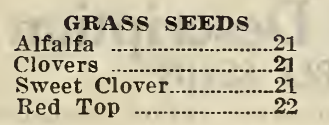

Bromus Inermis ......22 Ky. Blue Grass..........2? Eng. Blue Grass..........22 Orchard Grass................22 Rye Grass ......................22

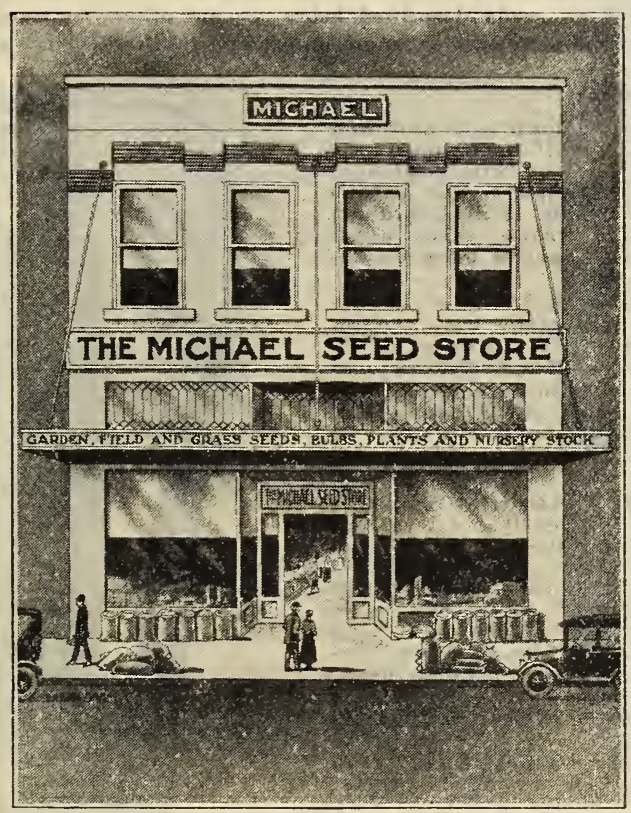

\section{THE HOME OF GOOD SEEDS}

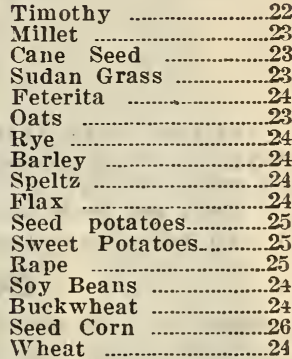

NURSERY DEPART. MENT, 32

Apples ............................32

Crab Apples .............33

Dwarf Apples ...............33

Cherries .............................33

Currants ..............................35

Plums ................................34

Pears ..............................34

Gooseberries ..................35

Buffalo Berries..............35

Grapes ...........................37

Blackberries .....................38

Raspberries .......................38

Strawberry Plants......36

Ornamental Shrubs....39

Spirea ..........................40

Climbing Vines............41

Hedge Shrubs ...............41

Ornamental trees..........42

Shade Trees ..................42

Weeping Trees ...........42

Roses ...........................44-44

Evergreens .....................45

Seedling:s ........................t8

\section{SUNDRIES}

Insecticides ....................46 Fertilizers .......................47 Poultry Foods .............48 Animal Foods .............48 Sprayers .........................48 Seeders (.............................48 Garden Implements....48 Inoculations …..............47 Semesall ...........................47

\section{THE HOUSE THAT MICHAEL BUILT}

A FrIENDLY TIP: Plant a home garden this spring. It is a sure cure for spring fever, a healthful exercise and a swat at the High Cost of Living. This applies to the city man, the suburbanite and the farmer too. For the latter it is a booll. Any farmer can save \$500.00 a year with a good home garden.

CATALOG: in handing you our new catalog we wish to express our thanks and appreciation and good will in days gone by.

VEGETABLE AND FLOWER SEEDS: We carry a full line of these seeds and they are the best the country affords. Purest quality, of strong germination, grown and carefully selected for us by special growers; men who exercise the greatest care to have the seeds choice, pure and reliable.

CLOVER AND GRASS SEEDS: Our field and grass seels are of superfine quality, extra recleaned, pure, free from foul and obnoxious weed seed as it is possible to render them by the best process of recleaning.

NURSERY STOCK: Our cellar arrangements for handling nursery stock surpasses anything in the country for keeping this stock in just as nice shape after it is dug up in the spring time and brought to our house as if it was just dug out of the ground when the purchaser comes to get it. We call your attention to page 32 for the Nursery Department.

DISCLAIMER: While we exercise the greatest care to have all seeds pure and reliable, it is positively understood we sell no seeds, plants, bulbs or nursery stock with any warranty expressed or implied in any respect and will not be in any way responsible for the crop. 


\title{
ag The Michael Seed Store
}

\author{
J. S. MICHAEL, Manager \\ 316 Pearl Street, Sioux City, Iowa \\ Auto Phone, 2142 \\ lowa Phone, 935-M \\ Prices and Description \\ VEGETABLE SEEDS
}

BEANS, PEAS AND SWEET CORN come first-other SEEDS in alphabetical order.

NotrCE-Prices quoted are f. o. b. Sioux City, Iowa. If ordered sent by mail, add 10c per pint, $15 \mathrm{c}$ per quart or $8 \mathrm{c}$ per pound to catalog prices.

Price per trade packet on seeds described below, except otherwise quoted: 8c each, 2 for $15 \mathrm{c}$.

All prices quoted are subject to stocks on hand and market fluetuation.

\section{Beans}

Beans are very sensitive to both cold and wet. It would be useless to plant them until the ground is warm. They can be safely planted first when the apple is in bloom. For garden culture make your rows about 18 inches apart and 8 inches apart in the rows. One quart plants about 100 foot rows. Special price on application in 50 or 100 lbs.

Golden Wax The old standard wax sort. ProGuctire and early with yellow semi-round pods of good quality. Prices: $1 / 4 \mathbf{l b}$. 10c; $1 / 2$ lb., 20c; 1 lb. 30c; 10 lbs. \$2.75.

American Black Wax The old standard Black American Wash Bean. The rittle. Jellow color. Prices: $1 / 4$ lb. 10c; 1/2 lb. 20e; 1 lb. 30c; 2 lbs. 55e; 10 lbs. $\$ 2.75$.

Round Pod Kidney Wax (Brittle Wax.) Is growth with heavy yielding vines; pods are long, round and entirely stringless; have fine flavor. One of the highest quality beans. One of the best of the round pods. Price: $1 / 416.15 c ; 1 / 216$. $25 \mathrm{c} ; 1 \mathrm{lb}$. 40c; 2 lbs. 75e; 10 lbs. $\$ 3.00$.

Davis White Wax A new, white, rustless, proDavis White Wax ductive, wax-podded bean; pods flat, very long, white waxy color, and handsume; seeds clear white. Price: 1/2 1b., 15c; 1 lb., 25c; 10 lbs., \$2.25.

Stringless Green Pod The earliest sorts of all large, handsome pods, six inches in length. Very productive, pods, perfectly round, straight, broad, tender. brittle, fleshy and entirely stringless. Prices: $1 / 4$ lb. 10c; $1 / 2$ lb. 15c; 1 lb. 30c; 15 lbs. $\$ 3.50$.

Extra Early Round Pod RedValentine Nothing ior to this dwarf green-podded sort, both for the home and market garden. Many prefer it to the wax varieties. Pods medium length, curved cylindrical, with crease in back. rery fleshy, crisp and tender. Price: $1 / 2$ 1b. 15e; 1 lb. 25c; 15 lbs. $\$ 3.50$.

Improved Dwarf Lima A true bush form of a circular bush 15 to 20 inches high, self-supported by its own thick stems. handsome pods. Price: $1 / 4$ lb. 10c; $1 / 2$ lb. 20c; 1 lb. 35 ; 10 lbs. $\$ 3.50$.

Large White Lima Vine, tall growing, requires borne in clusters, long, broad, dark green ; Price: $1 / 2$ lb. 20c; 1 lb. 35c; 10 lbs. $\$ 3.00$.

Kentucky Wonder, or old Homestead. Pole long, flat green pods, seven to nine inches in length, fleshy and stringless. Heavy yielder. Excellent for snap beans. Price: $1 / 4$ lb. 15c; $1 / 2$ lb. $20 \mathrm{c} ; 1$ lb. $35 \mathrm{c} ; 10$ lbs. $\$ 3.25$.

Field Bean The finest white field bean. Price: 1 lb. $15 \mathrm{c} ; 10$ lbs. $\$ 1.00$; per $100 \mathrm{lbs}$. \$8.00. Bags extra.

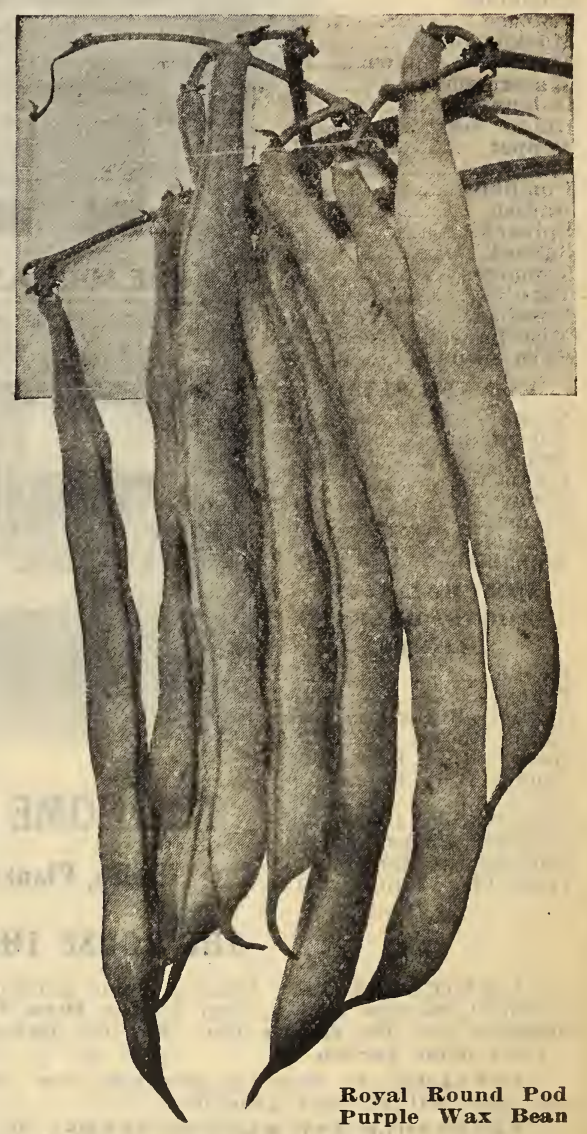

Royal Round Pod Purple Wax Bean This has specialty in wax beans now for several years, for it has proven itself to be one of the very best of all the wax sorts. We are the originators of it. The plants are good size without runners: leaves are dark green. Pods are very round and deep yellow in color, very brittle, stringless, without fibre, and unsurpassed in quality. For the market gardener who wants a first elass round poudded wax bean, this is one of the best that has ever appeared. Price: $1 / 4$ lb. 10c; $1 / 2$ lb. 20c; 1 lb. 30c: 10 lbs. \$2.50. 


\section{PEAS}

PEAS are among the earliest seeds that can be planted at the close of winter. The round, smooth sorts are the hardiest and are often planted without danger before the frost is out of the rround. The wrinkled sorts are not so hardy and cannot with safety be planted quite so early; but plant all kinds as early as possible and plant on a warm, quick, rich soil. Peas will mature earlier if planted only an inch deep. Where earliness is most important they should not be planted deeper, but larger pods and more of them may be had by deeper planting. Dwarf varieties are planted in rows 15 inches to 2 feet apart. Two quarts of seeds sow a hundred yards of rows.

Alaska or Earliest of All The vines are of medium height and of distinctive light color. The pods are of good size, about two and one-half to two and three-fourths inches long. Seed small, smooth, and bluish green in color. This sort matures all of its crop at once and is an invaluable variety for market gardeners and canners. Price: $1 / 4$ 1b. 10c; $1 / 2$ 1b. 15c; $1 \mathrm{lb} .25 \mathrm{c} ; 10$ lbs. $\$ 2.00 ; 25$ lbs. $\$ 4.00$.

Potlatch One of the largest, best and most productive of all the large podided Peas; superior to the Telephone, Harvester, Laxtonia or any of the others for a general home garden crop. Foliage a healthy dark green, growing to the height of about 20 inches. Crop maturing and ready to use in 60 days. Pods are borne in pairs, long, dark green, well flled with large berries. Second early. Planted at the same time you plant Little Gem and they come in right after the Gems are gone., Price $1 / 4$ lb. $15 \mathrm{c}$; per $1 \mathrm{~b}$. $35 \mathrm{c} ; 10$ lbs. for $\$ 2.50$.

Little Marvel New improved variety lately introduced. The most raluable home garden variety jet introduced, very early, large podded and a great cropper, 18 inches high, pods very dark green, produced in pairs and always well filled. Price: $1 / 4$ 1b. 10e; $1 / 2$ 1b. $20 c ; 1$ 1b. 35c.

Telephone The Telephone is medium early in season, bears a Telephone long time; the pods are always of good size. well filler and the quality is of the very best. Price: $1 / 41 b .10 c ; 1 / 2$ lb. $15 \mathrm{c} ; 1 \mathrm{~b}$. $25 \mathrm{c} ; 10 \mathrm{lbs}$. $\$ 2.00$.

Nott's Excelsior A very sweet, very dwarf, early pea, small Notes Excelsior about 15 inches high. Bears very heav. ily in a farorable season, but subject to weather conditions more than the smooth peas. Very high quality. Price: 1/4 lb. 10c; $1 / 2$ 1b. $15 \mathrm{c} ; 1$ lb. 25c; 10 ibs. $\$ 2.50$.

Michael's Early June Pea This is actually the earliest pea berry, it will stand planting two weeks Being a dented solid varieties without injury from weather conditions which hardy quality gives it an extra early start. The berry is bluigh green in color; vines grow about knee high and good averaged size pod; well filled and of a very

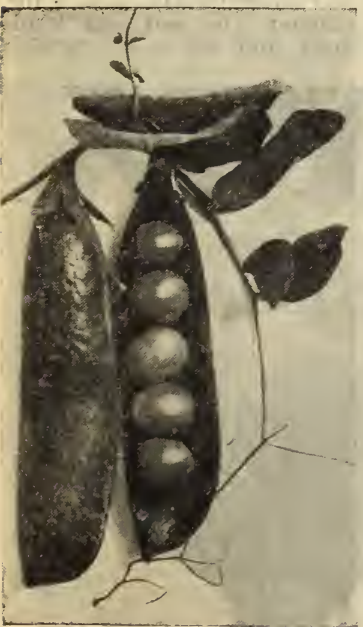
rich quality. Price per $1 / 4$ lb. 1Cc; $1 / 2$ lb. 15c; $1 \mathrm{~b}$. 25c; $10 \mathrm{lbs}$. $\$ 2.00 ; 25$ lbs. \$4.50.

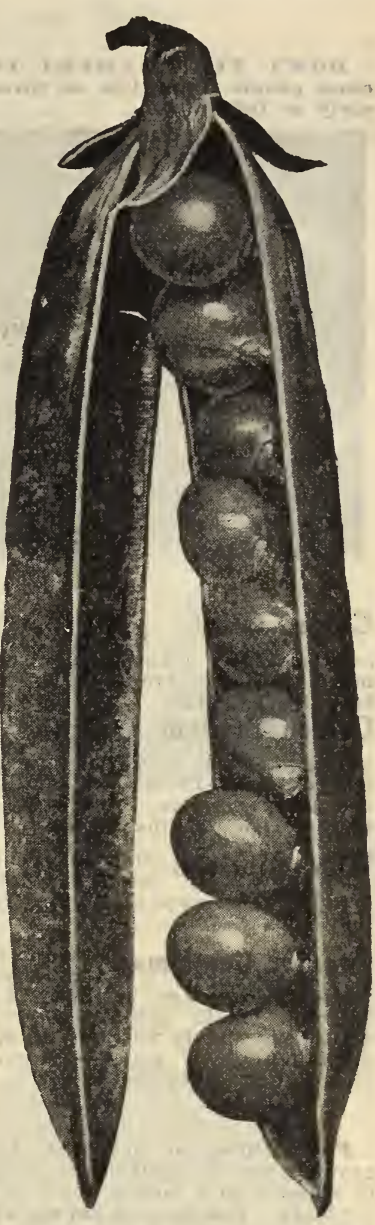

Potlatch

American Wonder Somewhat similar to Nott's Excelsior, a very early wrinkled pea; very dwarf. Pods quite large but not many to a vine. Prices: $1 / 4$ 1b. 10e; $1 / 2$ 1b. 15 c; 1 lb. $25 e ; 10$ 1bs. \$2.50.

Little Gem Probably the best known and most widely grown second early. It comes in following the first carliest, ant 15 to 18 inches high and bears heavily of large, plump pods. The peas are wrinkled and very sweet. Price: $1 / 416,10 c$; $1 / 21 \mathrm{~b} .15 \mathrm{c} ; 1 \mathrm{lb}$. $30 \mathrm{c} ; 10 \mathrm{lbs}$. $\$ 2.50 ; 25 \mathrm{lbs}$. $\$ 5.00$.

Champion of England The best late season tall pea. One of the er pea than the Champion of England. The vines grow almost 5 tous and produce a heary crop of good sized ports filled from end to end with luscious peas. Price: 1/4 1b. 10c: 1/2 1b. 15c; 1 lb. 25c; 10 lbs. \$2.25.

Marrowfat (Late) One of the oldest and best known peas. A Price: 1 lb. 20c; 10 lbs. \$1.75.

Edible Pod Pea This class of pea is but little known. They have a sweet, brittle. succulent pod, and can be used same as snap beans, cooking both rod aud pea together. Price: $1 / 4$ lb. 10c; $1 / 2$ 1b. $15 \mathrm{c} ; 1$ lb. $25 \mathrm{c}$.

Canada Field Pea A splendid crop to sow with oats or barley for green feed. Will produce a crop and enis rery prolitic. Price: 1 lb. 15c; 15 lbs. $\$ 1.75$. Per 100 lbs $\$ 5: 50$.

Bags extra. 


\section{SWEET CORN}

DON'T PLANT SWEET CORN DEEP-Sweet Corn should not be planted over one inch deep; most people plant two or three inches deep-most sure to rot. Also do not plant too early... Not as early as field corn.

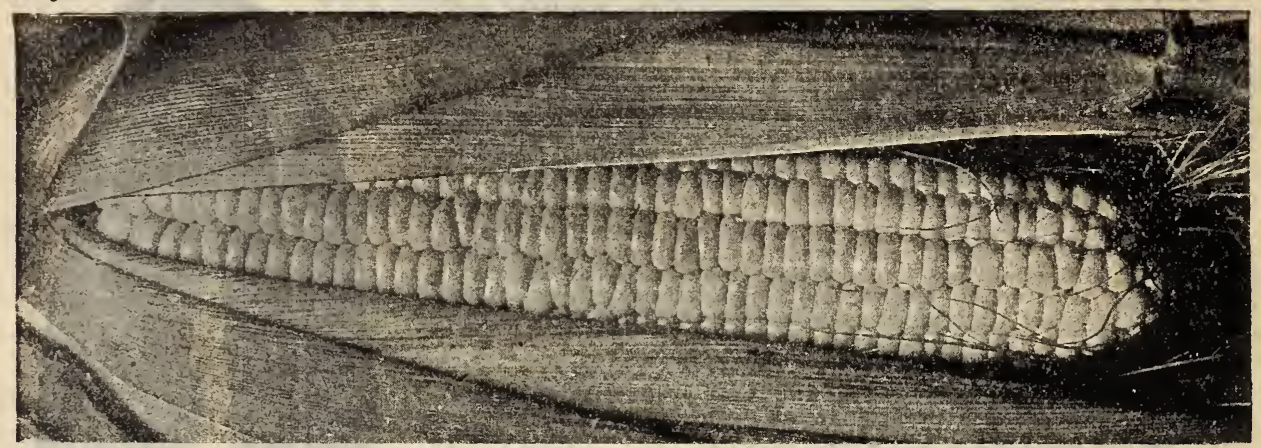

Golden Giant Sweet Corn

Golden Giant This is an early Sweet Corn recently introduced which is as early as the Golden Bantam. It is superior in size of ear and quality to that well known sort. The ears are fully a half larger; corn much sweeter, much more productive and as a roasting ear for market garden trade is much more desirable and a better seller. Price: 1/4 1b. 10c; 1/2 1b. 15c; 1b. 20c; 10 1bs. \$1.75.

Golden Bantam A yellow variety of sweet corn; all corns. It may be planted thickly and as late as July 15 with splendid results for table use as green corn. Price: $1 / 2$ lb. 10c; 1 lb. 20c; 10 lbs. $\$ 1.50 ; 25$ lbs. $\$ 3.00$.

White Mexican Originated at Sioux City. Early White Mexican as the Extra Earlies and far sweeter than any of them. Price: 1 lb., 20c; 15 ibs. \$2.25.

Country Gentleman This variety frequently an four good sized ears, is very small, giving good kernels of pearly whiteness. It is without doubt the sweetest and most tender of all sweet corn. Price: $1 / 2$ lb., $15 \mathrm{c} ; 1$ 1b. $25 \mathrm{c} ; 10$ ibs. $\$ 2.00$.

\section{TABLE BEETS}

For earliest tise sow seed of any round sort. Seed for main crop may be sown as soon as the cround can be gotten in proper condition. For table beets sow in drills 18 inches apart, and thin to stand 3 to 4 inches apart in the row. Use 1 ounce to 200 feet of drill and cover lightly; 5 to 6 lbs. per acre. Round and turnip shaped beets are the best for spring and summer; the half long kinds for winter. For sugar beets and mangels make the rows $2 \frac{1}{2}$ to 3 feet apart, and sow 6 to 8 pounds per acre. A light, loamy soil is best for all beets.

Early Wonder A rather new variety of recent introknown, almost round leaves, small, very dark rich crimson color. Price: $1 / 2$ oz. 10e; oz. 15c; $1 / 4$ 1b. $25 \mathrm{c}$; 1b. 75e. Extra Early Flat Egyptian An early variety. The tops round on top, but flat at bottom end. The color of flesh is light red. Price:....0z. 10c; $1 / 41$ lb. 25c; $1 / 21 b .40 \mathrm{c}$; 1b. 70c.

Crosby's Egyptian A variety of beet which has nearPlian ly supplanted the original Egyptlan and is more desirable because of its shape and fine quality. It is extremely early. Price: oz. 10c; $1 / 4 \mathbf{1 b}$. 25c; $1 / 2$ 1b. 40c; 1b. 75c.

Swiss Chard, or Spinach Beet The leaves of Swiss greens, cooked in the same mannard are used as oz. 10c.

Half Long Blood Dark Red flesh. Price: oz. 10c; Raif Long Blood 1/2 lb. 30c; Ib. 50c.

Long Smooth Dark Blood Price: oz. 10c; 2 ozs. 15c, Detroit Dark Red A grand beet with tops exceptionally small with small tap root. Color dark blood red. One of the best for market gardener and the home gardener. Price: 1 oz., 10c; $1 / 4$ lb. 25c; $1 / 2$ 1b. $40 \mathrm{c} ; 1$ 1b. 75e.

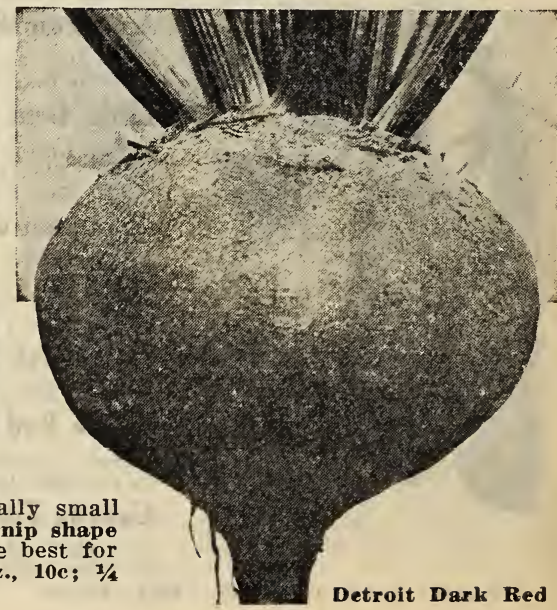




\section{Half Sugar Mangel Wurzel}

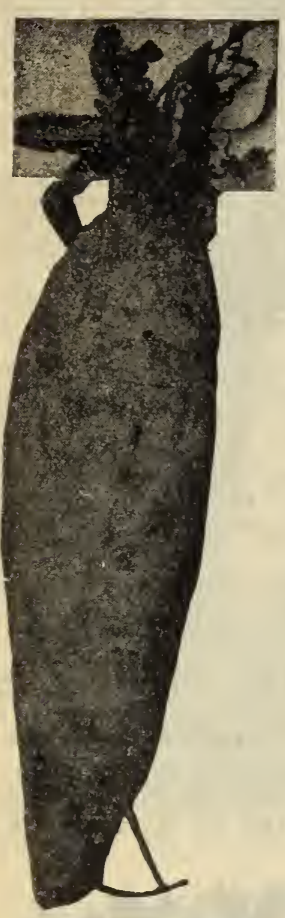

The Best for Stock A strain of beets very desirable for s to ck feeding, affording not only a very large crop much easier to harvest than other sorts, but much richer in sugar and other nutritive elements growing out of the ground. Can be harvested easily. Price: $1 \mathrm{lb}$., 50c; 10 lbs., \$4.00.

\section{Mangel Wurzel}

Mammoth Long Red

This is the heaviest cropping and largest of all mangels. The roots grow from onehalf to two thirds above the surface and are frequently two or more feet in length by six inches in diameter. Dark, richly colored foliage; skin bright red; flesh white, with veined rings of rosypink. Price: oz., 10c; 1/2 lb. 25c: 1 lb. 40c; postpaid, 10 lbs. $\$ 3.50$.

\section{Golden Tankard}

Best for dairy farm. ing. It is of rich, deep y e $110 \mathrm{w}$ throughout. Early, hardy and a heavy cropper. Price: oz., 10c; 1 1b., 50c; 5 lbs., \$2.25.

\section{Sugar Beets}

Sugar Beets may be grown in any tillable soll that is capable of producing good crops of vegetables. A few rows of Sugar Bets in the garden will be sufficient for a supply of syrup for home use. A bushel of Sugar Beets will produce about a gallon of syrup. Splendid for stock food. White French Sugar Prico: oz., 10c; 1/s lb.

Write for U. S. Department of Agriculture for Farm Bulletin No. 823 .

\section{Cauliflower}

One ounce of seed will produce about 8,000 plants.

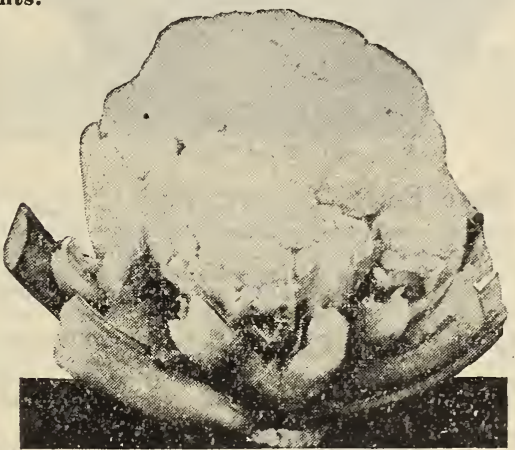

Cauliflower (Danish Grown Seed)

Early Snowball Esteemed for its earliness and ing large, solid, pure white heads; dwarf in habit and as early as any; one of the best sorts for forcing. Price: Pkt., 15c; 1// oz., \$1.00; 1/2 oz., \$1.50; oz., \$2.50.

Danish Giant One of the finest late varietles Danish Giant of robust habit; heads large, compact and thoroughly protected by leaves. Price: pkt., 15c; 1/4 oz., 80c; 1/2 oz., \$1.50; oz., \$2.50.

\section{CABBAGE}

Culture. The Cabbage is a great feeder and well repays heavy manuring and high culture. It succeeds best on well drained soil. Early cabbage may be started in early spring in a hotbed. For main crop, summer and autumn cabbage, the seed should be sown in a rich bed in the open air in May or June. Sow shallow; $1 \mathrm{oz}$. of seed to 4,000 plants, 3 to 4 ozs. for an acre. Set the plants 2 to 3 feet apart each way. Give frequent cultivation.

Early Spring Cabbage The earliest flat head. Wakefield. Yields more than the early pointed heads. Solid, uniform and finely grained. Price: $1 / 2$ oz., 15c; oz., 25c.

Early Jersey Wakefield Considered by many early variety. Of large size for so early a kind. Heads hard and solid, and have few outside leares. Our seed is extra select highest quality. American grown. Price: 1/2 oz., 10c; oz., 20c.

Danish Ball-Head (120 days) (Dutch Winter or Danish Ball-Head Hollander). The heads are of medium size, solid and deep, averaging in weight nearly eight pounds. Their quality is superior and they are just as solid in spring as when put away in the fall. Price: $1 / 2 \mathrm{oz}$., 10c: oz., 20c; $1 / 4$ lb., 75c; 1 b.. $\$ 2.50$.

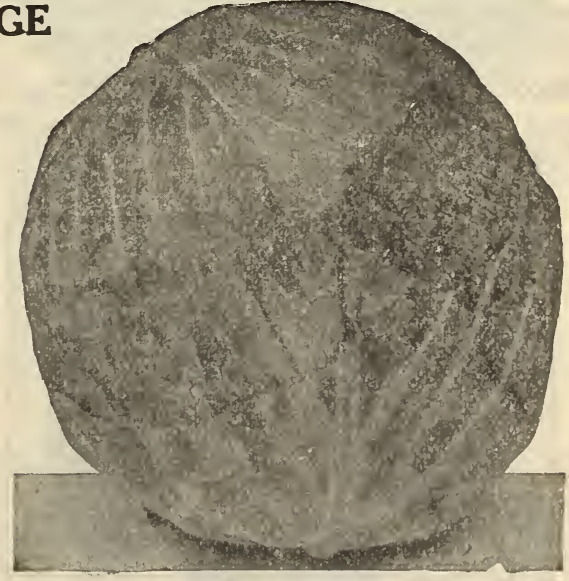

\section{New Early Cabbage}

Copenhagen An entirely new type of early TVabeloge. As early as Early Jersey better quality than either. Price: $1 / 2$ oz., 15c; oz. $25 \mathrm{c} ; 1 / \mathrm{lb}$., $\tau_{5 \mathrm{c}} ; 1 \mathrm{~b}$., \$2.50. 


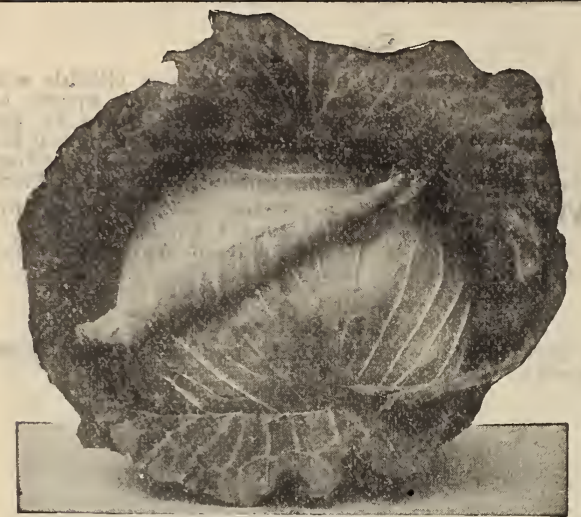

All Head Early

All Head Early All Head Early is of special All Head Early value because of close adherence to the type in habit of growth and the shape and quality of the head. Head large, very solid and flat. Quality excellent. By planting late it can be used also as a winter cabbage. Price: $1 / 2$ o\%., 10c; oz., 20c; $1 / 4$ lb., 75e.

Early Flat Dutch Cabbage A valuable second good size, solid heads; sells well and are good keepers. Price: 1/2 oz., 10c; oz., 20c; 1/4 lb., 75c.

Henderson's Early Summer An exellent secSame as All Head. Price: See All Head.

Henderson's Succession An excellent variety maturing in midsummer. Same as All Head. Price: See All Head.

Premium Late Flat Dutch This old and welltill the known variety is solid and first-class keeper. Price: $1 / 2$ oz., 10e; oz.. 20c; $1 \mathrm{~b} ., \$ 2.00$.

Late Drumhead A very Aeep, solid, sure headsoil will grow to a very large size: solid and excellent flavor. Price: $1 / 2$ oz., 15c; oz., 25c; lb., $\$ 2.75$.

Haco The earliest of all Red Cabbage... The good red color to the center. Price: $1 / 2$ oz., 50c; oz., $75 \mathrm{c}$.

For Cabbage Plants see page 31.

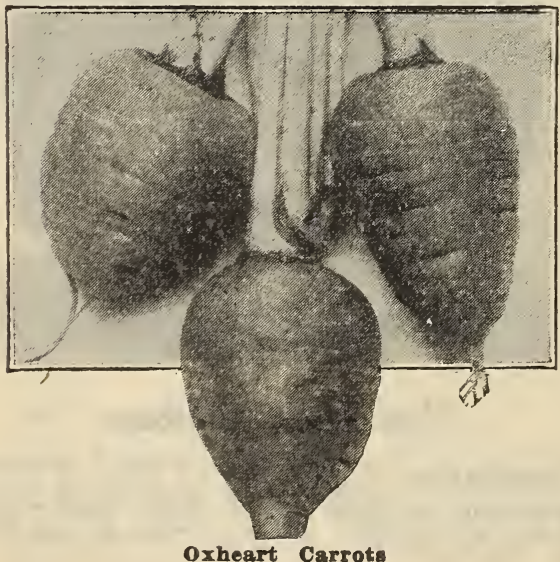

Oxheart Carrot:

\section{CARROTS}

Carrots require a deep, well worked soil. Plant in rows 15 inches apart for table sorts; cover $1 / 2$ inch deep: One ounce plants 50 feet. Carrots are excellent for stock, especially for horses. Sow any time before July 1st in rows 24 inches apart. Thin to 6 inches in the rows; two pounds of seed to the acre Store in winter the same as turnips. For feeding stock grow the White or Yellow Belgian, which yields big crops.

Oxheart or Guerande We do not hesitate to able variety in existence. It is intermediate between the Half Long and Horn varieties, attaining a diameter of 3 to 4 inches at the neck, of beautiful shape and rich orange color. It is excellent for hogs and other live stock and has yielded 1,200 bushels per acre. Price: oz., 10c; 1/4 ib., 25c; 1b., 75c.

Earliest Short Horn (French Forcing). This orange, of globular shape and excellent flavor. Price: oz., 15c; 3 ozs., 35e; $1 / 2$ lb., 75c; 1 b., \$1.50. Danvers Half Long A popular standard variety of rich, dark, orange color. In form halfway between Oxheart and the Long Orange, and wonderfully productive. Price: oz., 10c; $1 / 4$ 1b., 25e; 1b., 75c.

Chantenay Half-Long Resembling the Danvers, Medium early and heavy cropper. Price: oz., 10c; $1 / 4$ 1b., 25c; lb., 75c.

Improved Long Orange roots loll-known sort, $_{\text {thickset }}$ near the crown, tapering regularly up to a point, color deep orange. Price: oz., 10c; 2 oz., $15 c$; $1 / 2$ 1b., 40c; lb., 75c.

Large Yellow Belgian Used for feeding cattle; productive. Price: oz., 10c; 1/4 1b., 25c; $1 \mathrm{lb.,}$ 75c; 5 lbs., $\$ 3.00$.

\section{Celery}

One ounce will produce 5,000 plants.

Celery... Celery seed is slow to germinate and ample time must be given. Sow thinly and cover lightly keep constantly moist. Count on about 4,000 plants per ounce of seed. When the seedling plants are 3 inches high they should be clipped at the top. Favor stock growth or lse transplanted.

White Plume

\section{Celery}

The earliest celery. The easiest to grow, as it blanches without even earthing up. Price: $1 / 2$ oz. 10c; oz. $15 \mathrm{c} ; 1 / 4$ Ib. $75 \mathrm{c}$; 1 b. $\$ 2.25$.

Giant Pascal A superior keeping sort. The stalks are very large, solid, easily and retains its freshness a long time Price: $1 / 2$ oz. 10c; oz. 15c; $1 / 4$ lb. 75c; lb. $\$ 2.25$.

Golden Self Blanching The leading early vaer and heavier than those of White Plume, and superior in quality, while it is only a little later. Price: $1 / 2$ oz., 15c; oz., 25e; $1 b ., \$ 3.00$. 


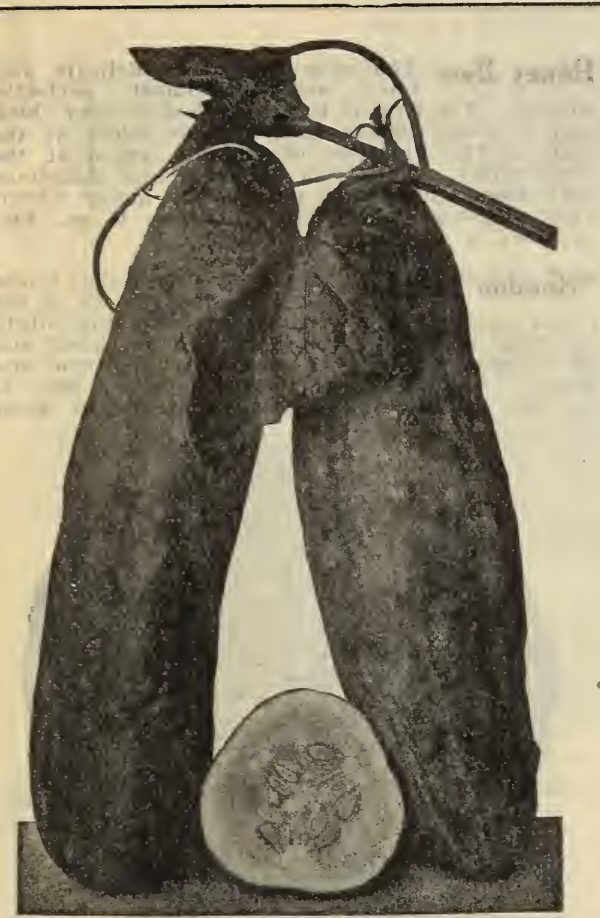

The Davis Perfect Cucumber

\section{CUCUMBERS}

Cucumbers thrive best on warm, rich, sandy soil, the richer the better. Crop should never be planted until soil is warm and the trees are out in full leaf. Plant in hills 4 feet apart and thin to about 4 plants to the bill. Second planting bout the middle of July for fall. One ounce for 50 hills.

The Davis Perfect Cucumber An excellent new both outdoor use and forcing. It is a most carefully selected strain of the White Spine type. It is slim, slightly pointed, a dark glossy green color, very tender, brittle and of fine flavor, vigorous grower, withstanding blight and disease better than other sorts. Price: $1 / 2$ oz. $10 \mathrm{c} ; 1$ oz. 15e; 3 ozs. $40 \mathrm{c} ; 1 / 2$ lb. $\$ 1.25 ; 1 \mathrm{~b}$. $\$ 2.25$.

Improved Early White Spine An excellent vaduces an early crop of cucumbers. The fruits are straight, light green, with white spines. Price: $1 / 2$ oz. 10r; 1 oz. 15e; 3 ozs. $35 \mathrm{c}$; $1 / 2 \mathrm{lb}$. 75e; $1 \mathrm{~b} . \$ 1.25$.

Early Cluster vine vigorous, producing the and in of the crop near the root and in short, with uniformly thick end. dark green, but paler at blossom end. A hardsy and rery productive sort. Price: $1 / 2$ oz. $10 \mathrm{c} ; 1$ oz. $15 \mathrm{c} ; 3$ ozs. $25 \mathrm{c} ; 1 / 2 \mathrm{lb}$. $75 \mathrm{c} ; 1 \mathrm{~b}$. $\$ 1.25$.

Early Frame Short Green This variety is an cor excellent sort, both orous, fruit straight, a little smaller at the ends, bright green, light at the blossom end. Comes into condition for use a little later than the Early Cluster. Price: 1/2 oz. 10c; 1 oz, 15e; 3 ozs. $35 \mathrm{c} ; 1 / 2 \mathrm{lb}$. $75 \mathrm{c} ; 1 \mathrm{lb}$. $\$ 1.25$.
Boston Pickling A distinct and very productive pickles. The fruits are of medium size, fory smooth, symmetrical and bright green. Price: 1/2 oz. 10e; 1 oz. $15 \mathrm{e}$; 3 ozs. $35 \mathrm{e}$; $1 / 2$ lb. $75 \mathrm{c} ; 1 \mathrm{lb}$. \$1.25.

Improved Long Green (Jersey Pickle). Fruits crisp. The small fruits are used for pickles and larger ones are excellent for slicing. The vines make a strong growth and are very productive Price: $1 / 2$ oz. $10 \mathrm{e}$; oz. $15 \mathrm{c} ; 3$ ozs. $40 \mathrm{c} ; 1 \mathrm{~b} . \$ 2.25$.

Klondike Cucumber This variety is one of the Klondike Cucumber best for slicing. The color is rich, dark green, and the fruits grow to a uniform size, measuring about 7 inches in length and 2 inches thick when in good condition to use. Price: $1 / 20 z .10 \mathrm{c}$; 1 oz. 15e; 3 ozs. $35 \mathrm{c}$; $1 \mathrm{~b} . \$ 1.75$.

\section{LETTUCE}

Culture. Lettuce, to be at its best, should be grown rapidly, hence the soil should be made as rich and friable as possible by liberal manur. ing and thorough preparation. For winter, sow under glass from November to February and thin out as necessary. For general crop, sow outdoors as early in the spring as the ground can be worked, in drills 18 inches apart, and thin young plants to 4 inches apart in the row. As the plants begin to crowd, thin them out and use as required. In this way a much longer succes. sion of cutting may be had from the same ground.

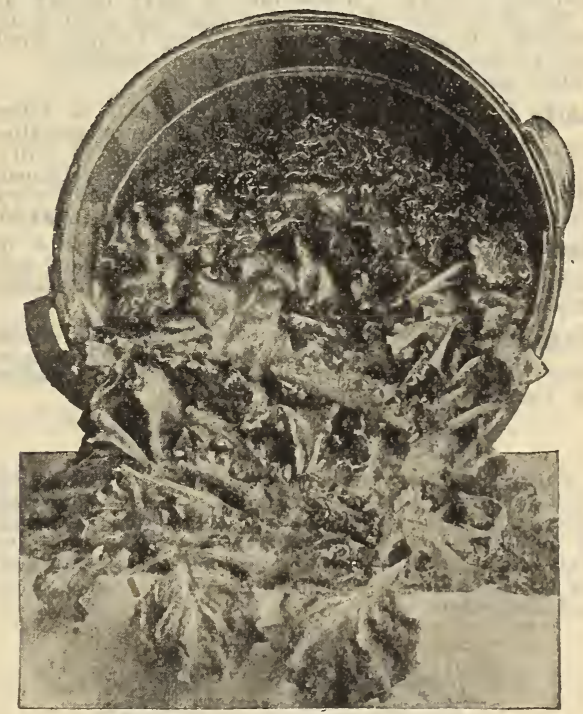

Black Seeded Simpson

Black Seeded Simpson Nearly double the size Black Seeded Simpson of an ordinary Curled Simpson. Stands summer well without becoming tough or running to seed quickly. By far the most popular variety for greenhouse forcing, mak. ing large handsome heads in a very short time. Price: oz., 10c; $1 / 4$ 1b., 35c; $1 / 2$ lb., 60c; 1 lb., \$1.00.

Grand Rapids (Seed black). A lettuce for green. hardy, little liable to forcing, quick growth, dition several days after being fit to cut. Wui stand shipping long distances better than most sorts. Price: oz., 10c; $1 / 4$ lb., 40c; $1 / 2$ lb., 75c: $1 \mathrm{lb}$., \$1.25. 


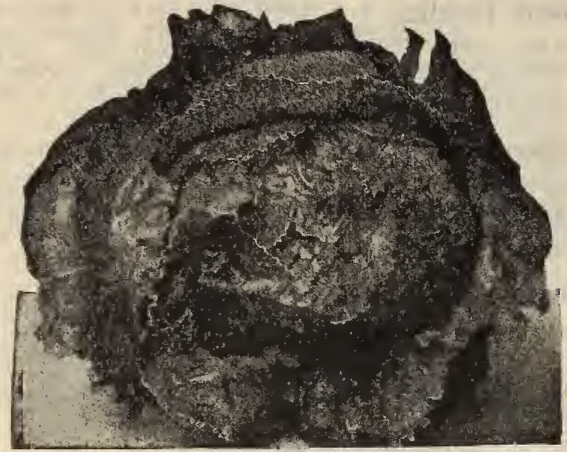

Big Boston

Big Boston. A (Seed White). Popular for large heading sort. Plants large, very hardy and vigorous; leaves broad, comparatively smooth, but wavy at edge, thin, very hard and crisp, color bright light green, the head slightly tinged with reddish brown. Price: oz., 10c; $1 / 4$ lb. $35 \mathrm{c} ; 1 \mathrm{lb}$. $\$ 1.00$.

New York This is one of the finest head letNew Yuce now being grown, extra tender and very brittle. While not as early variety as some it is one of the best for the garden or market. If you are fond of good lettuce don't fail to sow some of this excellent variety.

Price: oz. 15c; $1 / 4$ 1b. 60c; 1 b. $\$ 2.50$.

Early Prize Head. B (Seed White). A large clustering, non-heading lettuce. The most easily grown variety in cultivation. The leaves of the variety are crimped, bright green tinged with brownish red, very tender aud sweet. Price: oz. 10c; 1/2 lb. 70c; 1b. \$1.25. Early Curled Simpson White seeded. One of tuces. Quite similar to Early Curled Silesia. Price: oz. 10c; $1 / 2$ lb. 75̃c; 1 b. $\$ 1.25$.

Hanson Leaves are curly and tender and form a head as large as an early cabbage. Slow to run to seed. Creamy white inside. Price: oz. 10e; $1 / 2$ 1b. $75 \mathrm{e} ; 1 \mathrm{lb}$. \$1.25.

\section{MUSKMELON SEED}

Culture. Plant seeds in hills 4 to 6 feet apart each way, after danger of frost is over. Use well rotted manure in the hills. One ounce of seed to 50 hills; 2 to 3 pounds to the acre. A light warm soil is best. In hoeing, draw the soil well up to the plants. Fight bugs with tobacco dust and slug shot.

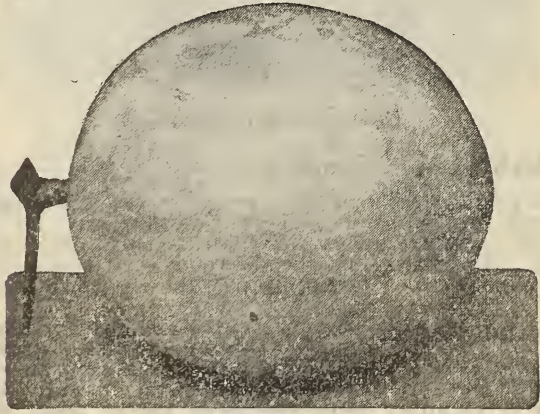

Honey Dew
Honey Dew The skin is a very delicate yellow; surface almost perfectly smooth. The rind is thin, the flesh is very thick and in color blends from a near white at the rind to the daintiest of emerald green at the seed cavity. The flesh is crisp and delicious, very sweet, juicy and possesses a honey flavor, very pleasing to the palate. Price: $1 / 2$ oz., 10c; oz. 15c; $1 / 4$ lb. $40 \mathrm{c} ; 1 \mathrm{~b}$. $\$ 1.50$.

"Hoodoo" Melon (Introducer's Strain). A new finest quality. Very vigorous, remarkably blight resisting and very productive. Fruits small and of uniform size. Netting exceptionally fine and dense. Flesh very thick. Price: oz., 15c: $1 / 4$ lb. 50c; lb. \$1.50. Introducer's Strain, 1 b. $\$ 3.00$.

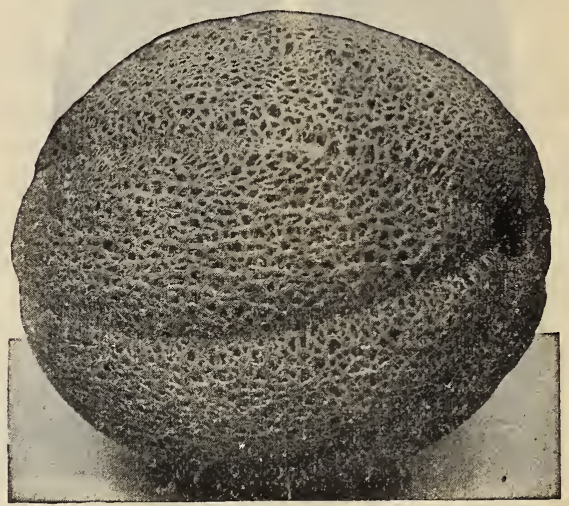

Rocky Ford

Rocky Ford (Netted Gem). The flesh is deep and thick, and light green in color. The flavor is exceedingly fine. The skin is regularly ribbed and thickly netted. It is a heavy cropper, and in wide favor as a market melon. Our seeds are saved from a field in which only seed melons are grown. Very dependable. Price: oz. 10c; 1/2 1b. 75c; 1b. \$1.25.

Emerald Gem One of the sweetest melons in Emerald Gem cultivation; smooth skin, deep salmon colored flesh; early and prolific. The ideal home melon. Price: $1 / 2$ oz. 10c; oz. 15c; $1 / 2$ 1b. $75 \mathrm{c} ; 1 \mathrm{~b}$. $\$ 1.25$.

Extra Early Hackensack Ten days earlier than Extra Larly Hackensack the old Hackensack. oz. 15e; $1 / 2$ lb. $\$ 1.00 ; 1$ b. $\$ 1.25$.

Hackensack or Turk's Cap The very largest Hack of all the nutmeg ends and have very broad ribs. Flesh is green, fine quality. Price: oz., 10c; $1 / 2$ lb., 60c; lb., $\$ 1.00$.

Osage (Salmon and Green). Medium to large in sized, oval, slightly ribbed, dark green thick. Covered more or less with shallow netting. Price: oz. 10c; $1 / 2$ lb. $75 \mathrm{c}$; $1 \mathrm{lb}$. \$1.25.

Early Citron Landreth's Very early half flat of fair quality. Price: oz., 10c; 1/2 lb., 60c; 1b., $\$ 1.00$.

Banana Cucumber shape. Delicious odor. Rather late maturing. Price: oz., 10c; $1 / 2$ 1b. $60 \mathrm{c}$; $1 \mathrm{~b}$. $\$ 1.50$. 


\section{WATERMELON SEED}

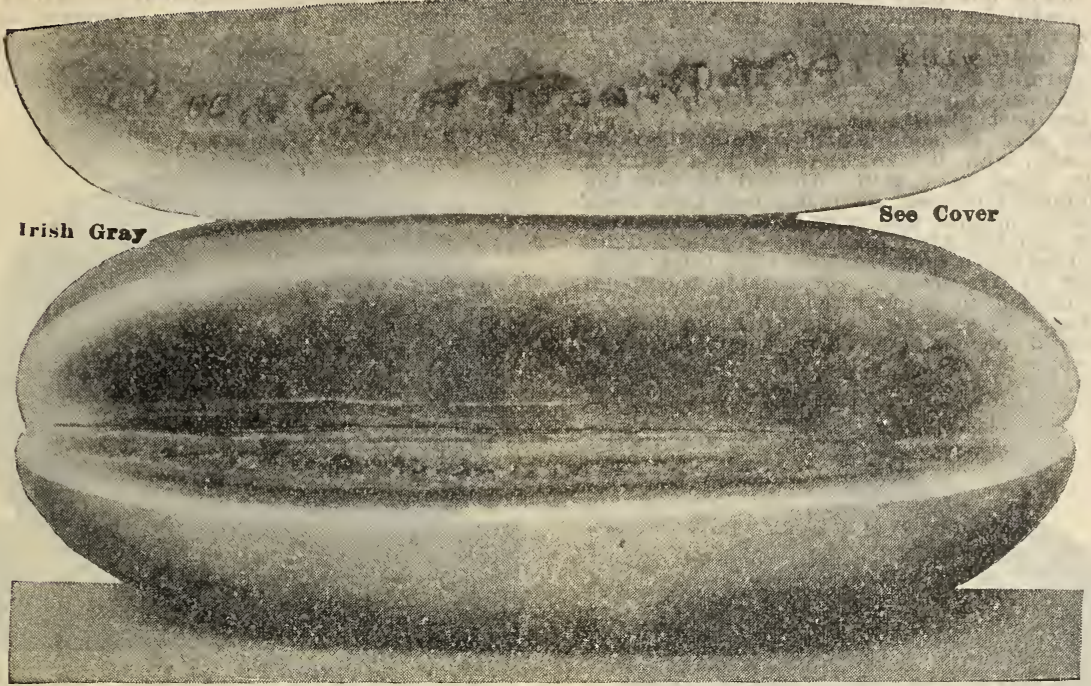

Ask or write for special price in large quantities.

Culture. The essential thing in melon culture is to get good strong vines early in the season. To this end plant your melons in hills 8 feet apart, made rich with some good fertilizer or well rotted manure thoroughly mixed with the soil. As soon as the ground is warm and dry plant 15 to 20 seeds in each hill, and thin out when the plants begin to grow, leaving only 3 to 5 of the most vigorous. Protect the young plants from insects and hasten their growth by the use of liquid manure. From 3 to 5 pounds plant an acre. Fight bugs with slug shot and tobacco dust.

One ounce will plant 50 hills and four pounds will plant one acre.

Irish Gray The old ones go and the new ones with a new dress, and then a same old girl grander than ever appeared before-as for instance the Honey Dew in Muskmelons, we now have the IRISH GRAY in Watermelons. A superb new sort just out. Bright, sparkling red flesh, sweet, firm, with a yellowish gray rind. For the home it's better and sweeter than Kleckley's Sweet; has a tough rind; better than Tom IVatson and outyields either of those a half more. It's the thing to catch the market with. Price: oz. $10 \mathrm{c} ; 1 / 4 \mathrm{lb}$. 35c; 1 b. $\$ 1.00 ; 5$ lbs. $\$ 3.50$. Monte Cristo or Kleckley's Sweets Unsurfor home use or near markets. Melons of medium size, oblong, tapering slightly towards the stem end; dark green. Flesh very bright rich red, exceedingly sweet. Price: oz. 10c; 1/2 1b. 75c; lb. $\$ 1.25 ; 5$ lbs. $\$ 4.00$.

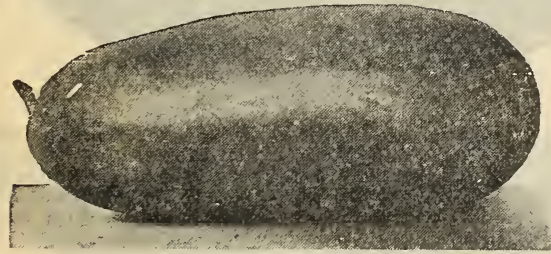

Monte Cristo or Kleckley's Sweets

McIvor's Wonderful Sugar (90 days). This most famous melon for sweetness and high qual. ity. The melons are long, averaging about 35 ibs. each. Rather light colored, irregularly striped and mottled with dark green. The rind is thin, but tough, so that it is a good shipper. Flesh is delicate, light red, entirely stringless, very tender, juicy and luscious. Price: oz., 10c; $1 / 3$ Ib. 60c; lb. $\$ 1.00$; 5 lbs. $\$ 4.00$; postpaid.
Cole's Early The earliest watermelon in cultiern states. Black seed, rich red flesh. Price: oz., $10 \mathrm{c}$; $1 / 2 \mathrm{Ib}, 40 \mathrm{c}$; $1 \mathrm{~b} ., 75 \mathrm{c}$.

Halbert Honey A variety somewhat similar to Georgia Rattlesnake Oblong, dark and striped;

Peerless or Ice Cream Very early; red flesh: Pood home melon.

Sweet Heart Mottled light green; large, oval, Cuban Queen Early, solid and heavy; skin Cuban Queen striped dark and light green.

Kolb Gem Very large; flesh red; a good shipNolb Gem ping sort; popular in the South.

Green Citron (Red seed). Round and handsome; for preserving only.

Above varieties not priced we quote as follows: Price: oz., 10c; $1 / 2$ lb., 40c; $1 \mathrm{~b} ., 75 \mathrm{c}$; in $5-1 \mathrm{~b}$. 10 ts and over, $60 \mathrm{c}$ per $1 \mathrm{~b}$.

Tom Watson A large, oblong melon, the skin rind is thin but tough and flesh a bright, attractive red color, crisp, sweet and delicious. Price: 0z. 10c; $1 / 2$ 1b. 40c; 1b. 75c.

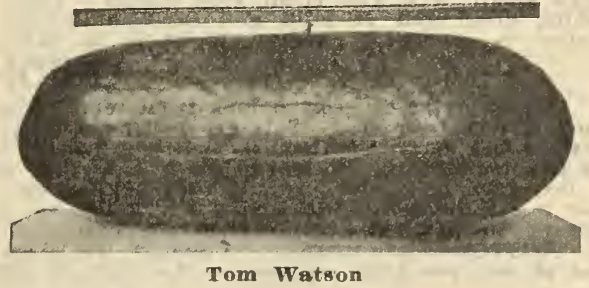




\section{ONION SEED}

The onion not only contains considerable nutriment and has valuable medicinal properties, but is most useful in counteracting the bad effects of sedentary life. The odor it imparts to the breath may be avoided by thorough cooking.

In onion culture, thorough preparation of the ground, careful sowing and the best of after culture, though essential, avail nothing unless seed of the best quality bo used.

Sow the seed as soon as the ground can be gotten ready, and it can be done best with a Planet Jr. hand seed drill adjusted to sow the desired quantity of seed about one-half inch deep. The quantity needed will vary with the soil, the seed used and the kind of onions desired. Thin seeding gives much larger onions than thick seeding. Four to five pounds per acre is the usual quantity needed to grow large onions.

Gathering. As soon as the tops die and fall the bulbs should be gathered into windrows. Cut off the tops when perfectly dry; leave lay a few days.

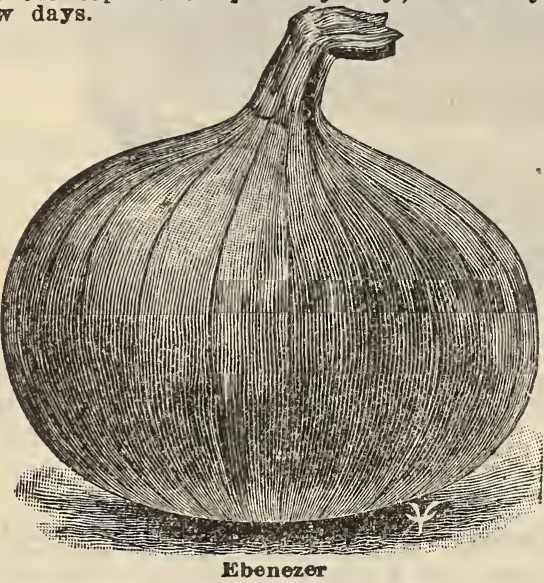

Ebenezer Onion This is a variety of onion of inated in a Mennonite Colony near Buffalo, New York. It was bred, it seems, from the multiplying variety of onions; on that account the foliage is not so pronounced and vigorous as other varieties, the strength of growth going into the formation of the bulb rather than the top. Produces onions of unusual size, very heavy yielder and superior to almost any variety known for keeping qualities. In appearance it is slightly globular with a rich yellow straw color. Price: $35 c$ per oz.; $\$ 1.00$ per $1 / 4$ lb.; $\$ 1.75$ per $1 / 2 \quad 1 b . ;$ $\$ 4.00$ per $1 \mathrm{~b}$.

Prizetaker (the largest onion grown; very mild). Price per 1b. \$3.00.

White Silver Skin, round, white, medium. Price per $1 \mathrm{~b}$. $\$ 3.50$.

Mammoth Silver Skin, a large, white onion. Price $\$ 3.00$ per $1 \mathrm{~b}$.

Now Queen, early, small white onion for pickling. Price $\$ 3.00$ per $1 b$.

Yellow Globe Danvers The most extensivel Bulbs of medium size, uniformly globe shaped with amall neck and ripen very evenly. Flesh white, crisp and of mild and excellent flavor. Price: $1 / 2$ oz. $15 \mathrm{c} ;$ oz. 25c; $1 / 2$ lb. $\$ 1.75 ; 1 b . \$ 3.00$.

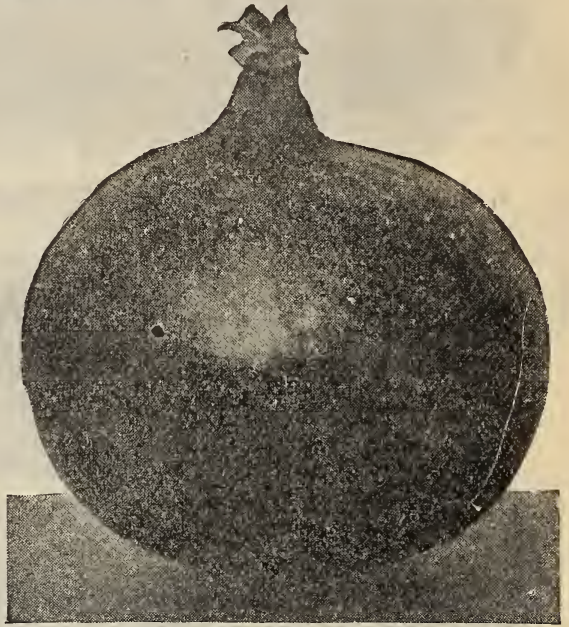

Southport Red Globe

Southport Red Globe On account of its beautiful shape and rich market and is an excellent keeper. The seed we offer is grown from true type bulbs. Subject to test before planting and if not absolutely satisfactory, money will be refunded. Price: 1/2 oz. 15c; oz. 30c; $1 / 2$ lb. $\$ 2.00 ; 1 b . \$ 3.00 ; 10$ lbs. $\$ 25.00$. White Globe This is the largest successful pure white onion in cultivation. Per: fect globe shaped, very solid; keeps well and always brings the top of the market. Price: $1 / 2$ oz. 15c; 1 oz. $30 \mathrm{c} ; 1 / 2$ lb. $\$ 2.00 ; 1$ lb. $\$ 3.50$.

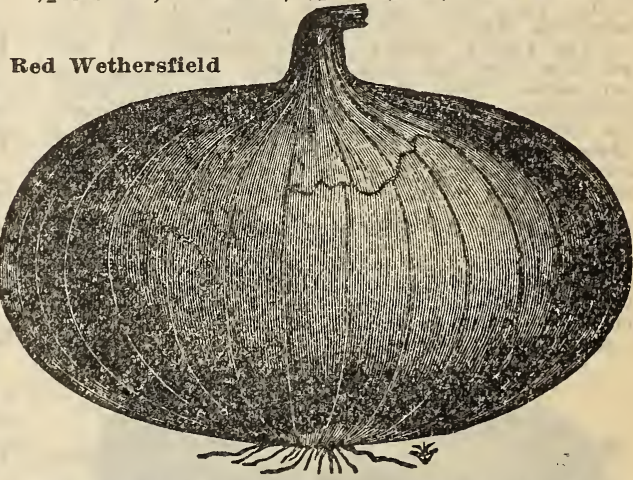

Large Red Wethersfield The best known of seller, great keeper the all the onions. Good sorts. My stock of this onion seed is most select and sure to grow. Price: 1/2 oz. 15c; oz. $25 \mathrm{e} ; 1 / 2$ 1b. $\$ 1.50 ; 1 \mathrm{~b}$. $\$ 2.50 ; 10 \mathrm{lbs}$. $\$ 20.00$.

\section{ONION SETS}

Manj prefer to grow onions from sets, as they are less trouble and are ready for use earlier than those grown from seed. Sete grown from seed are known as bottom sets. One quart will plant a row 50 feet long. Ten bushels will plant one acre. Multipliers are fine for bunching green. We sell by the pound only. Special prices in large lots on all varieties. Bottom Onion Sets, per lb., 15c; 3 lbs. 40c. Perennial Sets, 1b. 15c; 3 lbs. 40c; Garlic Bulbs 15e per 1b.; Ebenezer Onion Sets, 35e per 1b.; 2 lbs. 60c. Add 6c per 1b.; 2 lbs. 8c; 5 lbs. 14c; if by parcel post. White Bermuda Onion Plants 25c per 100 plants; $\$ 1.50$ per 1000 .

NOTIOE-ALL PRICES SUBJECT TO MARKET CHANGES AND STOCKS ON HAND. WhEN out of anj one kind we reserve the right to fill with next best at price of next best. 


\section{RADISH SEED}

Culture, For forcing under glass, scatter evenly over ihe surface 100 seeds to the square foot and cover with one-half inch of soil, sifted. For open ground culture, sow on rich, sandy soil as soon in the spring as it is fit to work, in drills twelve inches apart and thin out the plants if necessary to prevent crowding. A good dressing of nitrate of soda will greatly stimuate growth and insure tender and brittle roots. Successional sowing from one week to ten days apart will keep un a supply. After the hot weather of summer begins it is better to sow the summer and winter varieties, as they do not become tough and stringy nor pithy as the earlier sorts are apt to do when planted in late summer time. One ounce sows about 50 feet of row.

Remember, a succession is secured by planting seed every ten days.

SPECIAL PRICES 5 TO 10 LB. LOTS ON ALL SORTS.

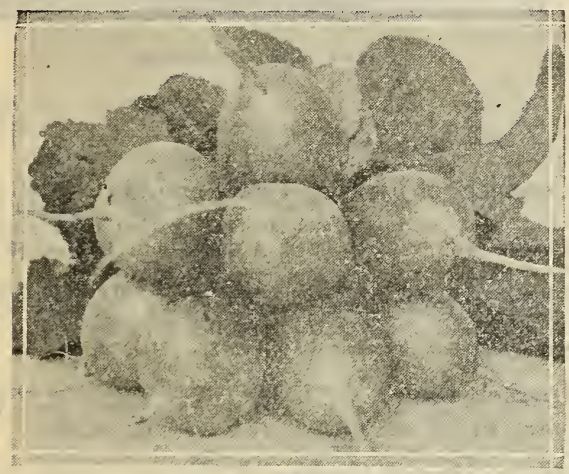

Saxa Globe Radish

Saxa Globe This is the quickest outdoor Radish known. On account of the remarkably small size of the leaves is indeed one of the safest and best for greenhouse culture. The flesh is firm and crisp, rich crimson, globe shape, and bulbs of even size. With favorable weather Saxa will be ready to eat in twenty days. Originated in Quedlinburg, Germany some years ago. Price per oz. 10c; 1/4 1b. 25c; per $1 \mathrm{lb}$. $75 \mathrm{c} ; 10$ lbs. $\$ 6.00$.

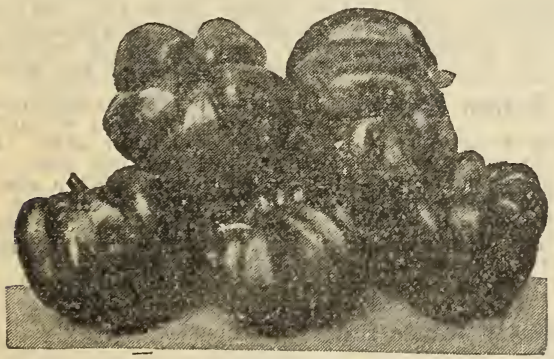

Ruby King
Cardinal Globe Radish This is the best foreing and quickest outdoor radish to date. A new 20-day variety. Remark. able for the small size of its leaves. The flesh is firm, crisp and fine quality, dark red, globe shaped bulbs of even size. Price: oz. 10c; $1 / 4 \mathrm{lb}$. 40c.

Icicle The finest eating, a most Distinctive Long White Radish... The best eating radish, and the best white variety. This sort has long, slender, pure white roots, which remain mild and crisp until they grow of larger size. Tops are quite short, making it early, and also allowing close planting. A succession is secured by planting seed every ten days. Prico: oz., 10o; $1 / 2$ lb., 40c; $1 \mathrm{~b}$., 75c.

Scarlet Turnip, White Tipped One of the the turnip radishes and a great favorite in many large markets for early outdoor plantlng. Roots slightly flattened on the under side, color very deep scarlet with a white tip; flesh white and of the best quality. Price: oz., 10c; 1/2 1b., 100; 1b., 75 c.

Early Scarlet Globe A desirable sort for hotplanting... Very early; top small. One of the best selling and most attractive radishes on account of its bright scarlet color and handsome shape; flesh white and tender, fit to pull in 28 days. Price: oz., 10c; 1/2 lb., 50c; 1 lb., 30c; 5 lbs., $\$ 4.00$.

Crimson Giant An early sort, looking much Crimson Giant like the old Early Scarlet Globe, but more perfect in shape. It comes early but keeps on growing and remains tender, solid and sweet until it gets as large as a teacup or larger. Price: oz., 10e; 1/2 lb., 60c; lb., \$1.00.

\section{Radishes}

$1 \mathrm{oz} .1 / 21 \mathrm{lb} .1 \mathrm{~b}$. p rooted ....\$0.10 \$0.50\$0.75

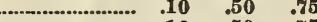

$\begin{array}{lllll} & \\ \end{array}$

Chartier Half Long White bottom.

White Strasburg ..................................10

Early White Turnip ..................................

\section{Winter Sorts} Rose White Winter $\$ 0.10 \$ 0.60 \$ 1.00$

Black Spanish, round or long.....

\section{PEPPER}

(One ounce will produce about 1,800 plants). Sow seed in hotbed early in spring: transplant to open ground when the weather is favorable. Seeds germinate slowly and require considerable heat.

Bull Nose Large blocky fruit, very mild. Pop1/4 1b. $\$ 1.60$.

Ruby King Very large size. When ripe they Rub are of a beautful bright ruby red color. Price: oz., 25c; $1 / 4$ 1b.. \$1.00.

Chinese Giant Most gigantic of all Giant Pepper, of enormous pers. A fine mild red pepflesh is mild and unusually thick. Price: $1 / 2 \mathbf{~ o z}$. $25 \mathrm{c} ; \mathrm{oz}$. $50 \mathrm{c} ; 1 / 4 \mathrm{lb}$. $\$ 2.00$.

Pimento Flesh extremely thick and very mild. Must be started early in the North to mature its fruits fully. $1 / 2$ oz. 30c; oz. 50c; $1 / 4$ lb. $\$ 1.60$.

Red Cayenne Pods long and slim, of medium $1 / 4$ lb., 75c.

\section{Topepo}

A hybrid Pepper with the Stone Tomato, producing a vegetable of attractive appearance in green and gold of gorgeously tinted effect. Excellent for salads, combining more or less the character of both the Pepper and Tomato. A novelty, des tined in time perhaps to become one of our leading vegetables. Well worth trying. Price per package, 25c. 


\section{Spinach}

An easily grown plant; the seed may be planted in the fall to secure good spinach early in the spring or even throughout the winter. The better and richer the soil, the larger and more tender the leaves will be. Use 8 pounds of seed per acre. For the home garden use one-half ounce for 100 feet of row.

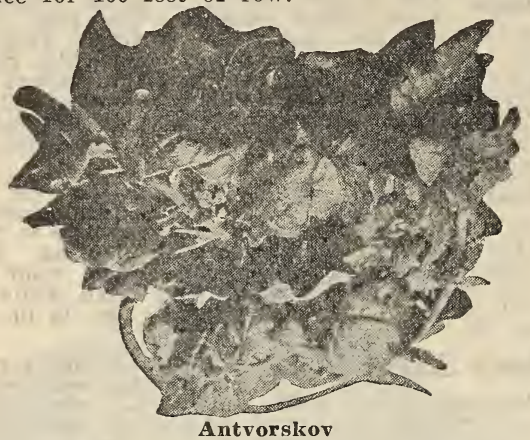

New Long Standing Spinach

"Antvorskov." (Danish King)

This variety is slower to seed than any other sort. Antvorskov forms quite large tufts, compact and low. The numerous leaves are extra large, broad and rounded, exceedingly bushy, slightly crumpled and of a glossy dark green color. It is vigorous and a rapid grower. It is ready for use practically as early as any Spinach and remains in condition much longer. Oz. 10c; $1 / 4$ lb., 25c; 1b., 60c; 5 lbs., \$2.50; 10 lbs. \$4.00. Bloomsdale Savoy The variety most generalBloomsdale Savoy ly used. Leaves large, round and thick. Very much savoyed and rich dark green. One of the earliest varieties. Price: oz. 10c; 1 1b. 50c; 10 1bs. \$3.50.

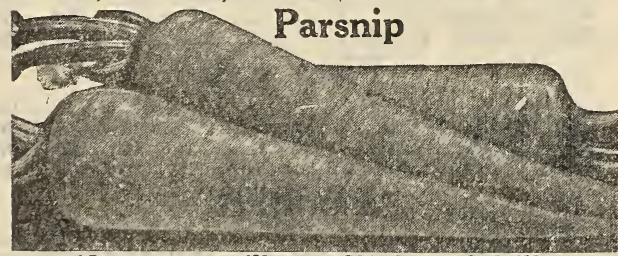

(One ounce will sow 200 feet of drill).

Sow early in spring in good, rich soil, which has been plowed deep. They are improved by frost.
Improved Hollow Crown
Fine grained and
excellent. per oz. $10 \mathrm{c} ; 1 / 4$ Ib. 25c; $1 \mathrm{~b} .75 \mathrm{c}$.

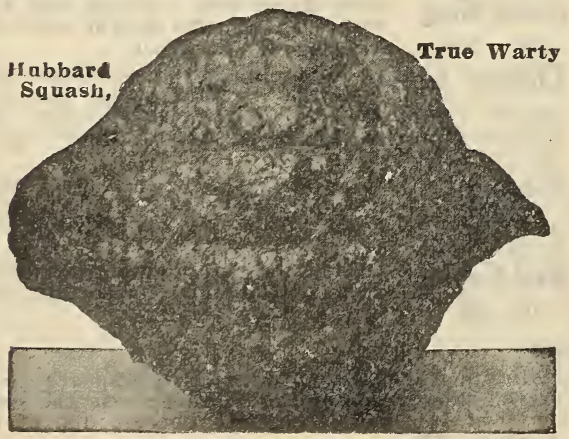

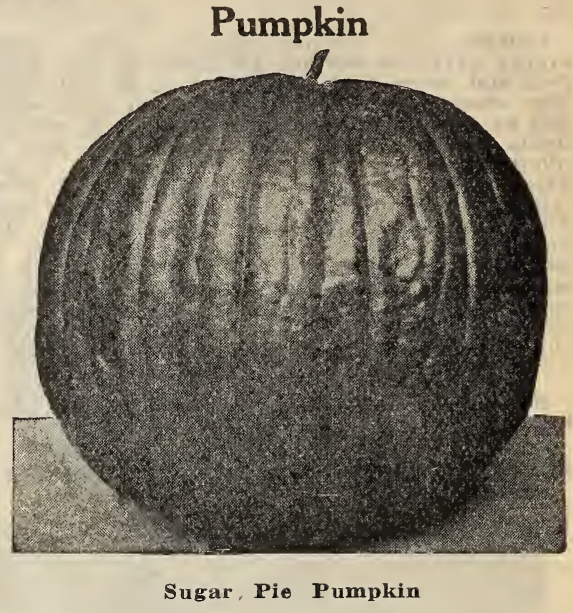

Culture. Plant from May to July in hills 6 feet apart each way. One ounce for 15 hills; two pounds to an acre.

Connecticut Field or Cow Pumpkin the big kind that is grown so much in the corn fields. Price: oz. 10c; 1 lb. 40c; 4 lbs. $\$ 1.50 ; 10$ lbs. \$3.50.

Small Sugar Best of all Pie Pumpkins. Very a Yankee Pumpkin, but smaller. Early and prolific. Price: oz. 10c; $1 / 4$ 1b. 35e; 1b. \$1.00.

Ouaker Pie A very prolific variety; a good pies. Price: oz., 10c; $1 / 4$ lb., 40c; lb., \$1.50.

Green Striped Cushaw Fruits very large, with creamy white, irregularly striped or traced with green. Flesh light yellow, very thick, rather coarse, but sweet. This sort is very productive and popular in some sections. Price: pkt., 5c; oz., 15e; 2 oz., 25c.

\section{Squash}

True Warty Hubbard The standard winter squash. Large, oliveshaped, with dark green skin and very rich flesh. Almost everyone is well acquainted with the Warty Hubbard. Our strain is extra fine and very warty. Price: $1 / 4$ 1b., 30c; lb., \$1.00.

Boston Marrow This is a very productive fall to large size, oval shape, and thin skin. It is much used for canning and making pies. The fruits when ripe are bright orange with a shading of light cream color. The flesh is of rich salmon yellow color, finely grained and of excellent flavor, but not as dry as the Hubbard. Price: oz. $10 \mathrm{c} ; 1 / 4$ lb. $30 \mathrm{c} ; 1 \mathrm{lb} . \$ 1.00$.

\section{Early White Bush Price: oz., 15c.}

Golden Summer Crookneck Price: oz., 15̄e.

Mammoth Chili A rery large and attractive vaMammoth Chil riety. The skin is a rich orange yellow, flesh thick, fine grained and sweet. Price: oz., 15c; $1 / 4$ lb., 50c; 1b., \$1.25. 


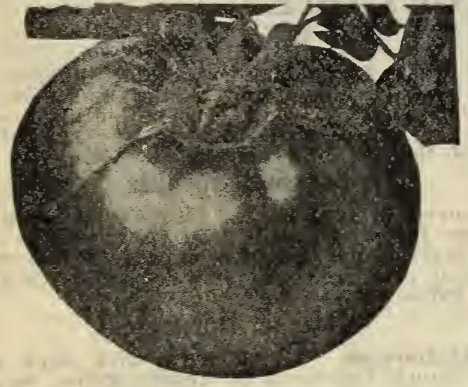

Bonny Best

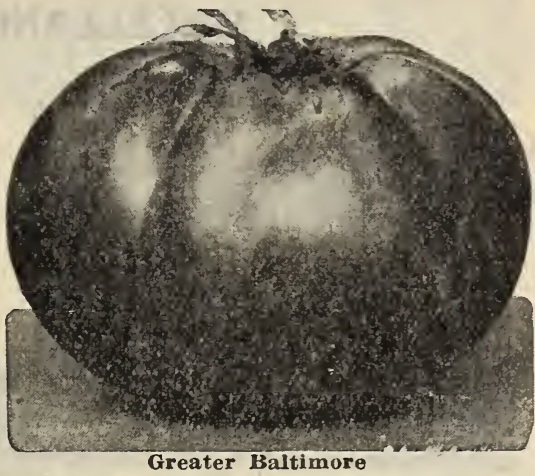

Greater Baltimore

\section{SPECIALLY SAVED TOMATO SEEDS}

Culture. Sow in a hotbed in early spring or the seed may be sown in shallow boxes and placed in a window when one does not wish to hare the trouble of making a hotbed. Transplant to the open ground when all danger of frost is past, setting the plants three or four feet apart each way. Cse Bone and Potash Fertilizer, or well rotted manure in the hills.

One ounce produces about 2,000 plants. For early crop sow in hotbeds in January or February. For late crop, in open beds in May.

Bonny Best The fruits of this desirable early Bonny Best sort are most attractive in shape and color. The crop ripens more uniformly than any other early scarlet fruited sort, and is of superior solidity and interior color. The vines are vigorous and produce a good crop of exceptionally round and deep fruits. One of the best for gardeners whose trade demands fruits of beautiful shape and color. Price: $1 / 2$ oz., 20c; oz., 35c; $1 / 4$ lb. $\$ 1.00 ; 1$ lb. $\$ 2.50$.

Dwarf Champion A purple fruited variety forming a stroug, erect. Tree Tomato. Fruit smooth, medium sized, fairly solid and of good flavor. Desirable for forcing, as it can be planted more closely on the bench than the tall growing kinds. Price: $1 / 2$ oz. 20c; oz. 35c; $1 / 41$ b. $\$ 1.25 ; 1$ lb. $\$ 4.00$.

Earliana The earliest, large, smooth, red Tomato. This Tomato is not only remarkable for its earliness, but for its large size, hand some shape and bright red color. Its solidity and fine quality are quite equal to the best medium and late sorts. Price: $1 / 2$ oz. 15c; oz. 25c; $1 / 4$ lb. 75c; per lb. \$2.75.

Ponderosa The largest rariety in cultivation. The rines are vigorous and rery productive. The fruits are very solid, with exceptionally few seeds, fairly smooth and of very good quality. It is very desirable for slicing. Price: $1 / 2$ oz. 25c; $1 / 4$ Ib. $\$ 2.00$; per $1 \mathrm{~b}$. $\$ 7.00$.
We do not use canning factory seed.

Early Acme One of the earliest and handsomest smouth varieties. Medium size, perfectly fusely. Dark red with purplish tint. Price: $1 / 2$ oz. 15e; oz. 25c; $1 / 4$ lb. $85 \mathrm{c} ; 1 \mathrm{~b}$. $\$ 3.00$.

New Stone One of the heaviest and most solid New Stone fruited of the large tomatoes. Vines vigorous and productive. Fruit round, slíghtly flattened, very large. very rich scarlet. Price: $1 / 2$ oz. 10c; oz. 15e; $1 / 4$ lb. 50c; lb. \$2.00.

Dwarf Stone Plants grow dwarf and stocky, like those of Dwarf Champion, and can be set out close together. The fruit is like Stone, solid and deep red, and of fine quality. Ripens a little earlier than Stone. It is worth planting in every home garden. Price: $1 / 2$ oz. 20c; oz. 35̃e; $1 / 4$ lb. $\$ 1.25$.

Golden Queen A very handsome yellow tooz., 10c; oz., 20c.

Greater Baltimore This mid-season or main Greater Baltimore crop variety is extensively used for canning, and is also a desirable home garden sort. The fruits are of medium to large size, are solid and meaty and ripen evenly. Color, rich bright red. Similar to Stone, but fruits ripen earlier. Price: 1/2 oz. 15c; oz. 25c; $1 / 4$ 1b. $\$ 1.00 ; 1 b . \$ 2.50$.

Yellow Pear and Yellow Plum A small selis grown for preserves. Price: $1 / 2$ oz. $25 \mathrm{c} ;$ oz. $40 \mathrm{c}$. Other Varieties We can supply any of the here or not. For Tomato Plants see page 29.

\section{TURNIPS}

Early Turnips should be planted rery early. and will keep growing until the ground freezes. Extra Early White Milan The earliest turnip. rery erect and compact. Price: oz., 15c; 1/2 lb., $60 \mathrm{c} ; 1 \mathrm{~b} ., \$ 1.00$.

Extra Early Purple Top Milan Similar to the except the upper portion is a beautiful purplered. Price: oz., 15c; $1 / 2$ lb., 60c; $1 b ., \$ 1.00$.

Purple Top, Strap-Leaved The most popular sort. More largely size bulbs in seven or eight weeks. Price: oz., 10c; $1 / 21$. $40 \mathrm{c} ; 1 \mathrm{~b}$. 75c.
Late Turnips can be sown in July or August Use 2 pounds of seeds to an acre.

Purple Top White Globe Of a perfect shape skin. Flesh pure white, firm and crisp and of quick growth. Price: oz. 10c; 1/2 lb. 40e; 1b. 75e.

\section{Rutabaga or Swedes}

Improved American Purple Top For the fine productiveness this is the best. The roots are finer and larger than the ordinary; the flesh is a rich yellow. Price oz., 10c; $1 / 2$ lb., 40c; $1 \mathrm{~b}$., 65c. 


\section{MISCELLANEOUS VEGETABLES \\ Asparagus \\ Kohl Rabi}

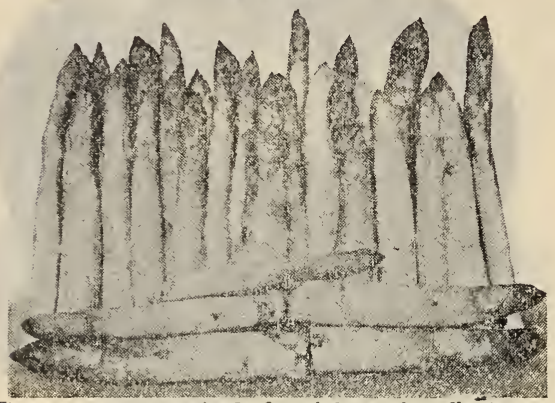

Tiu dsfiarigus bed furnishes the first green delicacy for the tiable in the spring, is universally ponular aud requires but little care.

Bonvallet's Giant. Price: oz., $15 c$.

Columbia Mammoth White. Price: oz., 10c.

Conover's Colossal. Price: oz. 10e.

Asparasus Roots. 'Two years old. See page 31.

\section{Cress or Pepper Grass}

Early Curled. IVell-known salad. Sow at intervals all season. Price: oz., 20c.

True Wrter. Sow seeds along the border of runniug water. Price: $1 / 2$ oz., 20c.

\section{Egg Plant}

A tender plant that should be started quite early in a hother n... transplanted.

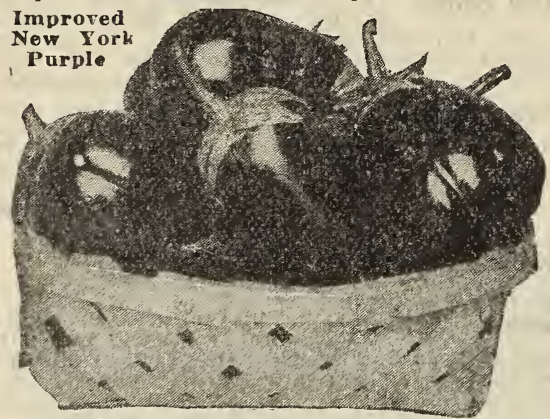

New lork lmproved Large Purpie. Fruits large, nearly round, dark purple, free of thorns. Price: $1 / 2$ oz., 30c; oz., 50c.

Black Beauty. Fruit large, symmetrical in shape and of a rich dark purple color. Iittle earlier than our linproved Large Purple. Price: $1 / 2$ oz., 30c; oz., 50c.

\section{Endive}

(One ounce will sow about 60 square feet).

One of the best salads for fall and winter use. Sow seed in April for early use or in June or July for winter use. When leaves are eight inches long tie thew together with a string near top to blanch. Price: oz., 15e.

\section{Broccoli}

The cnlture is the same in all essentials as for cauliflower. Withstands greater extremes of temperature than canliflower.

Early White Vienna... Extremely early, with distinctly sinall tolss. Price: $1 / 2$ oz. 15.

Rarly Purple Vienna. Very early, with sinall top, the left stems being tinged with purple. Price: $1 / 2$ oz., 15e.

\section{Mustard}

New White Chinese. Leaves tender and delicious. Price: $0 z, 100$

The Kohl Rabi is a vegetable intermediate between the cabbage and turnip and somewhat resembles each in flavor. The edible part is a turnip shaped bush formed by the enlargement of the stem. Price: $1 / 2$ oz., 15c.

\section{Brussels Sprouts}

Improved Half Dwarf. The plants grow two to three feet high and produce from the sides of the stalk numerous little sprouts which resemble small cabbages one or two inches in diameter. Price: 1/2 uz., 25c.

\section{Kale or Borecole}

Dwarf German. Very hardy, with dark green leaves; much improved by frost. Price: oz., 15c.

Dwarf Curled Scoteh. Dwarf, beautifully curled, bright green. Price: oz., 15c.

\section{Leek}

Belongs to the onion family. Set the roots deep and draw the earth to them when cultivating.

London Flag. The variety generally eultivated in this country. Price: oz., 20c.

\section{Parsley}

(One ounce will sow 150 feet of drill).

Sow very early, thinly in drills one foot a part and half an inch deep. Soak seed in warm water a few hours before sowing.

Cliampion Moss Curled. A very select stock, finely crimped and curled. Price: oz., 10c; 1/4 lb.. 25e; Ib., 75e.

H:amburg. Turnip-rooted variety; used for flavoring soups.

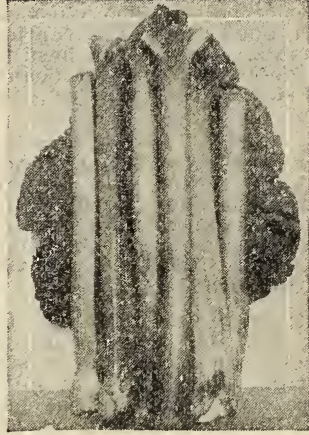

Largo Victoria Rhubarb
Rhubarb seed.

Easily raised from

Large Victoria. The s t a n d a r d variety. Price: oz., 10c; $1 / 4$ lb. 30c; 1b., 85c; postpaid. For Rhubarb Roots see page 29 .

\section{Salsify}

Mammoth Sandwich Island. By far the largest and best for market. Roots of superior quality and double the size of the old variety. Price: oz. 25c.

\section{Swcet Herbs}

Anise Seeds, aromatic $1 / 2$ oz.

Caraway

Catuip (Cat Mint) 0.10

Coriander, for flavoring

Dill (2 uz., 30c; $1 / 4$ lb., 50c)

Lavender

Marjoram, Sweet

Saffron

Sage, Broad Leaf

Savory, Summer

Thyme

\section{Mushroom Spawn}

Mushroom Culture. Mushrooms may be grown any place where the conditions of temperature and noisture are favorable. A shed, cellar, cave or vacant space in greenhouse. Twelve page vamphlet telling how to prepare bed, plant and grow the crop, 25c each, free with order for $\$ 1.00$ worth of spawn.

We carry the American Spawn Co's Pure Mushroom Spawn, conceded to be the best spawn sold. Alway's fresh.

American Spawn, in bricks, each .......................\$0.30

One brick, by mail, postpaid 

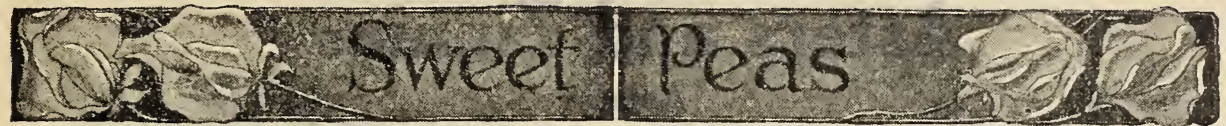

Sweet Peas. Sweet Peas are among the most heautiful of all our hardy annuals. Select a sunny, open place sereral feet from any building and as far as possible from large trees. Sow as early in the spring 28 possible. Plant in rows and have the rows trenched for planting 4 to 6 inches deep. In dry weather water freely and keep the flowers picked closely. If allowed to go to seed the plants will stop blooming.

\section{Spencer Standards Varieties}

The Spencer Types are exceptionally large size, with long stems, the wings waved or frilled and the effect remarkably graceful and attractive. All Spencers are decidedly shy seeders. The price higher than for the older (Grandiflora) type. We offer in the different shades, what we consider to be the best varietles.

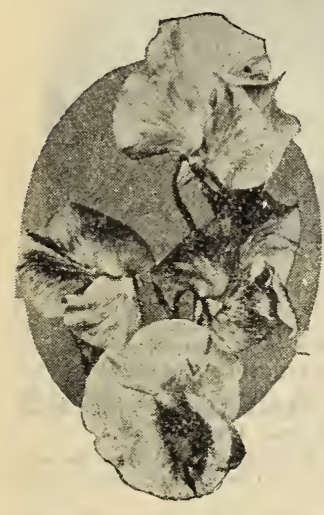

Spencer Typo Apple Blossom Spencer $\begin{gathered}\text { (Rose Snencer). Standard with primrose } \\ \text { wings. Very iarge; true spencer form. }\end{gathered}$ Per 1/2 oz.. 10c; oz.. 20c; 1/4 lb., 60e; lb. \$2.25.

Blanche Ferry (Pink Spencer) risually a little darker than flowers show striping. It is one of the most attractive varietles ever introduced. P'er $1 / 2$ oz.., 10c: oz., $20 \mathrm{c} ; 1 / 4 \mathrm{lb}$., 60c; 11 .. $\$ 2.25$.

Etta Dyke (White Spencer) Standard and wings of pure white, especially attractive variety of rery large size. Per $1 / 2$ oz.. I0c: oz., 20c: $1 / 4$ lb.. 60e; 1b. $\$ 2.25$.

Mrs. Hugh Dickson (Salmon Pink Spencer) A light on (ream growers: throws four flowers to a sten $1 / 416 . .60 \mathrm{c} ; 1 \mathrm{~b} . \mathrm{s} .2 .5$.

King Edward VII (Red Spencer) The best pure red Spencer; mense wings. Per $1 / 2$ oz., 10c; oz., 20c; $1 / 4$ lb., 60c.

The President A brilliant orange-scarlet flower, always of largest The President size. The bloons, usually in fours, are carried on strong stiff stems. Per $1 / 2$ oz., 15e; oz. $25 \mathrm{c} ; 1 / 4 \mathrm{lb}$., 7.5e.

Spencer Mixed All the Spencer varieties includer in making colors is thus assured in remarkably lare. A splendid range of colors is thus assured in remarkably large size and wonderfil at $1 / 4 \mathrm{lb}$., 50c; $1 / 2 \mathrm{lb}$., 90e; 1b., $\$ 1.50$.

\section{GRANDIFLORA TYPE}

Eckford Mixture This is an old and well known mixture of Grandiflora type. Contains some of the entire list and cannot fail to give the very highest satisfaction of the Grandiflora Sweet Peas that have for years been the pride of the flower garden. Price: per $1 / 2$ half $0 z ., 5 c ; 0 z ., 10 c ; 1 / 4$ lb., 25e; 1b. 60c.

\section{Nasturtiums}

\section{Giant Flowering}

Nasturtium. Few flowers equal the Nasturtium in richness and variety of colors, freedom of bloom and ease of culture. They are suitable for bedding and handsome climbers, grow quickly, thrive in the poorest soil and furnish the greatest abundance of long lasting, sweet scented cut flowers.

King Theodore (Tall Growing). Rich, deep, crimson flower; Nast striking and beautiful of all tall growing Nasturtiums. Foliage dark green and vigorous. 1/2 oz., 10c; 1 oz.,

Michael's Zulu Scarlet, dark leaved; darker than Brilliant or in Fulgens and the nearest to Empress of India Per 1/2 oz., 10c; 0z., 15c; 2 oz., 25c

Nasiurtiums Lobbianum (Lobb's Nasturtium). This is a disof of flowers surpassing the old fashioned kind for size and rich colors with overlapping petals on each flower. All colors mixed. $1 / 2$ oz., 10e; 1 oz. 15e; 2 oz. 25c; $1 / 41 \mathrm{~b}$. $40 \mathrm{c}$.

Tall Mixed (California Giants). In this mixture will be found DeLuxe Giant Mixture. Per oz., 10c; 1/4 1b., 25c; 1b., 75c.

King of Tom Thumb A dwarf variety with intense deep scarlet $1 / 4$ lb 35c.

Dwarf (Mixed). A special mixture of Dware eren Nasturtium of a great many colors in eren proportions. Michael DeLuxe Dwarf Mixture, Per oz, 10c; 1/4 1b., 25c; 1b., 75c,

Dwarf King Theodore Velvety red flowers lage, Price 10c per oz., $1 / 4$ lb., 35c. 


\section{Asters and Zinnias}

Asters

In their many varieties and colors, are the grandest and most beautiful flowers that bloom in the home garden.

Michael's New Creation Aster ( $\begin{gathered}\text { Heart of France) } \\ \text { The richest red }\end{gathered}$ Aster erer developed. Color livid, ox blood red with a sheenish tinge in the sunshine like burning coals. Secund early bloomer. Plants grow abont ? feet with free branching habit. Flowers are double borne on stems about a foot long. Bulk pkt. 10c: 1-16 oz. 15e: 1-8 oz. 25c; 1 oz. \$1.50. Extra Early Express or Early Wonder These the eurliest blouming Asters, commencing to bloom with us in July. Flowers large and full, of the Comet type. Finest mixed. Bulk pkt. ǰr. 1-16 oz., 15c; 1-8 oz.. 250": 1 oz.., \$1.00.

Michael's Dwarf Royal 'T'hese are a dwarf Asters about 15 to 18 inches high, coming into bloom early in the season following the Early Express. Double flowered and very attractive. Finest mixed. Bulk pkt. 5e; 1-16 oz. 15c; 1/s oz. 25c; oz. \$1. Michael's Giant Branching This is a new have developed after several seasons of Hybridizing and selection. It is a branched variety of trme non-lateral stems. Has an immense flower of great beanty and substance of the Crego or Ostrich Feather type throwing no single flower. Michael's De Luxe Mixture, brik nacket 10c: 1-16 o7., 15c; 1-8 oz., 25̃c; 1 oz., \$1.00.

Michael's Giant Branching, White

Bulk pkt. 10c; 1-16 oz., 15c.

Michael's Giant Branching, Purple

Bulk pkt. 10c; 1-16 oz., 15c.

Michael's Giant Branching, Shell Pink

(Mary Semple), daybreak pink. Bulk pkt.

$10 c$; 1-16 oz., $15 c$.

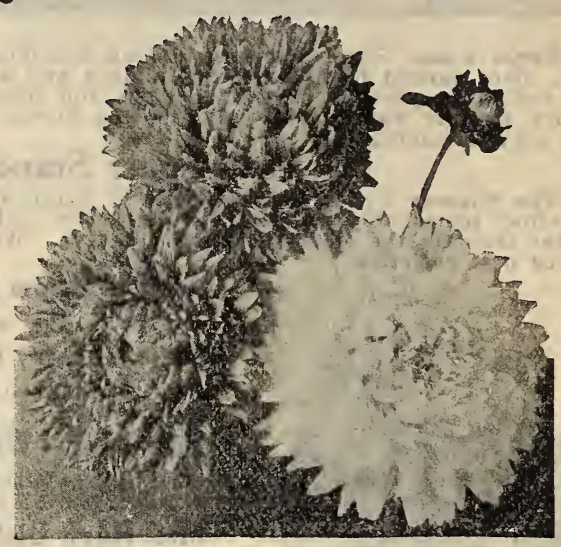

American Beauty Aster

American Beauity This new type of Aster of the most attractive of all large flowering branching sorts. vigorous grower and profuse bloomer with whorled center as the flower unfolds. Comes in three shades: Michael De Luxe Mixture. Bulk pkt. 5c; 1-16 oz., 10c.

Carmine Rose Beauty Regular American Beauty 1-16 oz., 15̃c.

Purple Beauty Richest of all purple Asters. White Beauty Snow white with intense effect.

\section{Zinnia}

Showy plants with large, double flowers. Might be taken for dwarf dahlias. Few flowers are more easily grown or bloom more abundantly throughout the season.

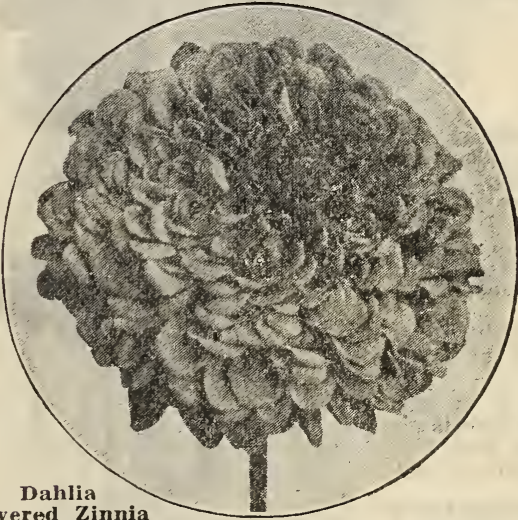

Flowered Zinnia

\section{$\mathrm{N}$} of colors not only including the usial shades, but many unusual tones, such as salmon, old rose, cerise, strawberry-red, etc. Michael's DeLuxe Mixture. Bulk pkt. 10e; 1-16 oz, 20c; $1 / 8$ oz. 35.
DAHIIA ZINNIA (Named Sorts)

Exquisite This is by far one of the most pleasing colored Zinnias of any of the named varieties of the Dahlia flowering and is a true Dahlia type in regard to size and form. The color is light rose with a deep Tyrian Rose center. Bulk packet, 25c; 1-16 oz. 50c.

Meteor A rich glowing spinel red and the darkest of all red shades. Fine form and good denth petal. Very large and mole floriferons than any other of the reds. Price 1-16 oz., 25̌c; 1-16 oz. 5̃0c.

Oriole The most beautiful Dahlia Zinnia of its class. All immense orange and gold bicolor. changing slightly as it ages, worthy of the beautiful bird for which it is named. Bulk pkt. 25c; 1-16 oz. 50c.

Crimson Monarch By far the largest and best Crmson of the red shades of Dahlia Bulk pkt. 20c; 1-16 oz. 40c.

\section{COMIION ZINNIAS}

Double Giant A special strain of this grand Double Giant old flowering annual, which proances flowers of colossal size, specimens measuring from 5 to 6 inches across. Michael's De Luxe Giant Mixture. Bulk pkt. 10e; 1-16 oz., 25e; 1-8 oz., 25c.

Jacqueminot Zinnia This splendid red flowerang Zinnia is just corout the summer until frost, with the effect of reil American Beauty roses. Bulk pkt. óc; 1-16 oz. 15e; 1-8 oz. 25e, 


\section{Pansies and Petunias}

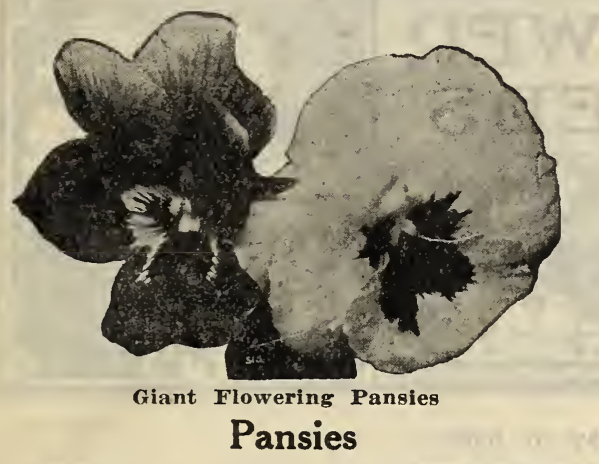

PANSIES are now produced in almost infinite colors and markings. After years of experimenting with the many varieties we have finally reached a climax of perfection in the Pansy proposition and what we offer in our DeLuxe Mixture (Identical) is the last word to be pronounced in Giant Pansy. The seed can be planted in early spring time, or for greenhouse work in August and September for forcing under cold frames for the purpose of plants in early spring time. See page 31 for Pansy Plants.

Michael's Giant DeLuxe Mixture This conspecial strains, too expensive to list in catalogs and can only be had in this DeLuxe combination which besides, includes the richest reds, copper and bronzes together with the most delicate rose pink shadings and the Master Piece strain with its delicate veinings and ruffled petals. Immense flower, expressice facings, brilliant colors, all in one glorious combination. Price: Small bulk pkt. 10c; medium sized pkt. $15 \mathrm{c} ; 1-16$ oz., 35̃; $1-8$ oz. $60 \mathrm{c} ; 1$ oz. $\$ 4.00$.

White Pansy Pure white Giant strain, without blotches and without eye. Yellow Pansy Rich golden yellow without Yellow Pansy blotches and without eye. Bulk packet $15 \mathrm{c}$; 1-16 oz. 25c; 1-8 oz. $40 \mathrm{c}$.

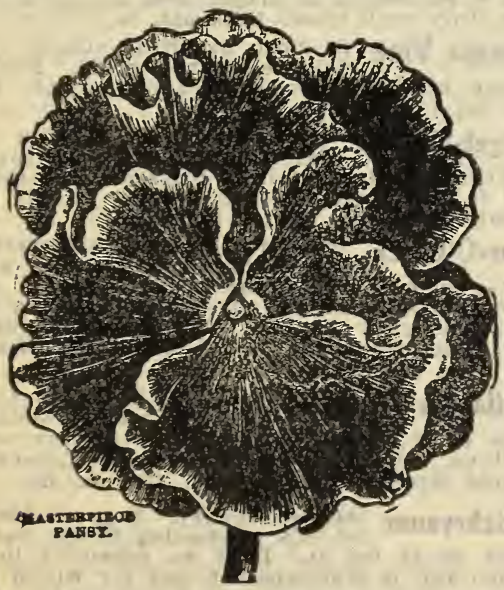

Masterpiece (Now Giant Curled or Spencer Paned and fled petals are crimped, curlor less double. Bulk packet 10c; 1-16 oz. 35c; $1-8$ oz. $60 \mathrm{c} ; 1$ oz. $\$ 4.00$.

\section{Petunias}

For freedom of bloom, variety of color and effectiveness these have no equals. If only a little care is bestowed upon them. Petunias will produce their handsome. sweet-scented flowers in their delicate and gorgeous colors throughont the whole summer.

LARGE-FLOWERING SINGLE SORTS

Michael's De Luxe Mixture. Large flowering. Bulk packet 10e: 1-16 oz. 25c.

\section{BALCONY PETUNIAS}

Balcony Petunias A splendid free flowering variety of single Petunia; about 12 inches high: flowers average 3 inches across. Especially valuable for windows, porch boxes, vases, among rock work, terraces and equally as effective in beds and borders.

Michael's DeLuxe Mixture. Bulk packet 10c; 1-16 oz., 25c; $1 / 2$ oz. $\$ 1.75 ; 1$ oz. $\$ 3.00$.

BAICONY BLUE. True velvety blue-of great substance.

BALCONY ROSE. Brilliant rose-pink-very effective.

BALCONY WhITE. Pure, dazzling snow-white.

BALCONY CRIMSON. Rich, velvety crimson.

PRICE: Above 3 kinds. Bulk packet, each 10c; 1-16 oz. 35e: $1 / 4$ oz. $\$ 1.25 ; 1$ oz. $\$ 1.00$.

\section{SINGLE BEDDING PETUNIAS}

General Dodd (Hybrida) One of the most Ventiful blood red Velrety flowered Petunias among the dark and crimson colored varieties. A flower of great substance. Blooming continuously all season Bulk packet 10c; 1-16 oz., 20c.

Howard's Star A beautiful, free flowering with a clearly defined five-pointed star of blushwhite. For bedding, baskets, vases, etc., this is exceptionally fine. Bulk packet 10c; 1-16 oz. 20c. Rosy Morn Soft carmine-pink with white at the same time effective border plant. Bulk pkt. 10c; 1-16 oz. 15c; 1-8 oz. 25c; 1/2 oz. \$1.25.

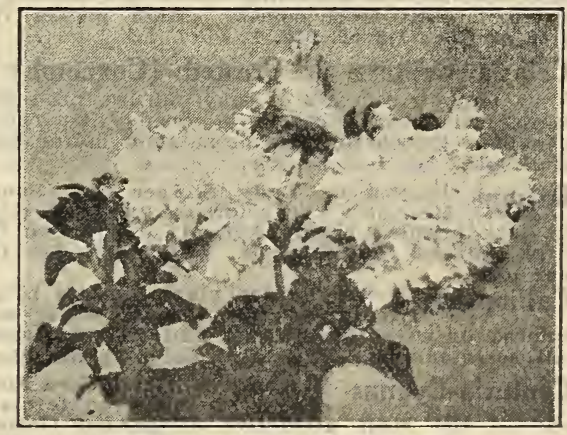

Michael's Double Fringed

LARGE-FLOWERING DOUBLE PETUNIAS Michael's Superb Double Fringed (Grandiplena Finbreata. Saved from our own unrivaled collection; will produce a large percentage of louble flowers of the largest fringed varieties in bright colors. Michael De Luxe Mixture. Per 100 seeds, 25c.

\section{Dwarf Petunias (Nana Erecta Compacta)} This beantiful type is particularly suited for beds and border. Plants form round bush like clumps, literally covered with thousands of flowers, glistening in the sunlight and last from June until frost. Michael's De Luxe Mixture, Bulk packet 5c; 1-16 oz. 15c. 


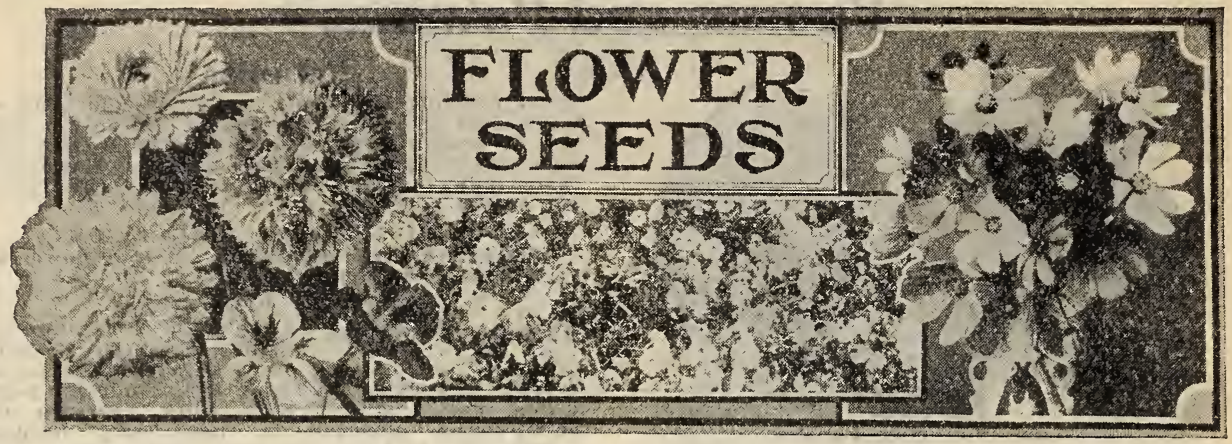

GENERAL LIST (in bulk)

Are better, cost less, more certain to grow than paper seeds.

One of the most cherished recollections that we have of our mother's or grandmother's home is that of the beautiful array of brilliantly colored flowers-marigolds, daisies, pansies, balsams, asters, pinks, poppies, nasturtiums and other flowers in great array.

Alyssum Procumbens (Carpet of Snow). This this sweet scented annual. It grows 2 inches high with the appearance of a flat pancake. The mass of blooms completely hide the foliage, giv. ing the appearance of a covering of snow. Bulk pkt. 5c; 1-16 oz., 15e; 1-8 oz. 25e; 1/2 oz. 50c.

CARNATION, “Florists Pink." Easily grown from seed; free blooming; flowers bright with clove like fragrance. Half hardy perennial.

Margaret These are deservedly the most popular Margaret Carnations with the amateur. This strain is extra fine quality, producing an abundance of large, double, beautifully-fringed, highly scented flowers. All colors mixed, Bulk pkt., 5̃c: 1-16 oz., 10c.

Celosia (Plumosis). Distinct variety bearing a profusion of beautiful ball-shaped woolly flower heads of intense scarlet. Sometimes called the Wool Flower. Surpassing the Red Geranium in blooming effect and blooms all summer until frost comes. Bulk packet 10c: 1-16 oz. 15c; 1-8 oz. 25c.

\section{Celosia Cristata or Crested (Coxcomb)}

Very popular annuals of easy culture, producing large, ornamental, comb-like heads like ruffled chenille. Prized for pots or summer flower beds. Bulk pkt., 5c; 1-16 oz. 15c.

Balsam Known as Lady slipper and TouchBalsam Me-Not. The colors range from white to dark purple. Hardy Annual, one to two feet high. Mixed Double Sorts. Bulk pkt. 5e; 1-16 oz. 10c.

Calliopsis Showy border plant, flowers bright yellow or rich brown, either selfcolored or with these colors and red contrasted. All sorts mixed. Bulk. pkt., 5c; 1-16 oz., 15c.

Centuria-Cyanns (Bachelor Buttons, Corn FlowCenturia-Cyanus or) in its improved forms is one of the most attractive of garden flowers. One to two feet high. Double mixed. Bulk pkt. 5c; 1-16 oz. 15c.

Centaurea Imperialis (Sweet Sultan) Thls ful sweet scented flower of artistic shape is borne on long strong stems and is undoubtedly the finest of all this class for cut flower purposes and will last several days in good condition. Bulk pkt. 10c; 1-16 oz., 15c.

Coreopsis Very showy, free flowering plants, Coreopsis native of this country, fine for bor5c; 1-16 oz. 15c.

Cosmos A very effective autumn flower, bushCosmos like plants 3 to 5 feet high, and covered with large, single, dahlia-like flowers. Barly Flowering. Mixed Bulk pkt. 5c; 1-16 oz., 10c.
Cosmos-Double Flowering (Double crested or anemone flow. ered) A new creation in this beautiful late summer and autumn blooming plant, furnishing an abundance of blooms for decoration when other flowers are scarce. Bulk pkt. 10c; $1-16$ oz. 25c.

Double Flowering, White Bulk pkt. 15c; 1-16 Double Flowering, Crimson Bulk packet.

Candytuft Showy, branching plants oz. 25c. twelve inches high; will bloom from July to September, or if planted in the fall from May to July. All sorts mixed. Bulk pkt. Ec; 1-16 oz., 15c.

Castor Bean (Ricinus). Tall, majestic plants Cor lawns, with leaves of green of very quick growth in rich soil. Zanzibariensis, very large green; and the Gibsonia, beautiful bronze foliage. Bulk pkt. 5c; $1 / 2$ oz., $15 \mathrm{c}$.

Calendula (Officianalis). This variety has large flowers resembling in size rm the finest Aster. It blooms profusely with a succession of bright deep orange flowers from July until frost. Bulk pkt. 5c; 1-16 oz. 15c. Cypress Vine A most beautiful climber with foliage, scarlet blowica, dark green, feathery pkt. 5c; 1-16 oz., 15c.

Forget-Me-Not (Myosotis). A ravorite oldprofusion clusters of blue blossoms. It thrives well in the shade or open border. Hardy perennial. Bulk pkt. 10c; 1-16 oz. 15c.

Four-0'Clock (Marvel of Peru). The flowers are Fur-O Clock funnel-shaped and open about four o'clock, in the afternoon and remain open all night and generally perish before noon next day; will grow in any soil. Hardy annual, 2 feet high. Bulk pkt. 5c; 1-16 oz. 10c; 1-8 oz. 15c; $1 \mathrm{oz} .25 \mathrm{c} ; 1 / 4$ lb. 60c.

Gaillardia (Blanket Flower) Borne on strong stems; blooming quite early; bright gay colored flowers which continue to bloom until frost. Lorenziana Double Mixed. Bulk pkt. 5e; 1-16 oz. 15c.

Helichrysum (Straw Flower). A great demand duced us to list it. It is an or flower has the garden and is everywhere prized for winter decorations in vases as permanent bouquets. Bullk pkt. 10c; 1-16 oz., 15e; 1-8 oz. 25c.

Heliotrope Highly valued for the fragrance of their flowers and duration of bloom. Bulk packet 10c; 1-16 oz. 25c. 
Kochia or Summer Cypress (Kochia Tricopornamental annual, having a cypress-like appearance. Its bright autumn coloring has given it two other names: "Mexican Fire Plant" and "Burning Bush". Bulk pkt. 5e; 1-16 oz. 10e.

Larkspur (Delphinium) Quick growing, free blooming annual with erect spikes of beautiful flowers in great profusion. Strictly an annual distinctly different from Delphinium perennial. Bulk pkt. 5e; 1-16 oz. $15 \mathbf{c}$.

Lace Flower (Didiscus Coeruleus) Beautiful ian annual; well-known flower of our grand parents with a blossom like the Queen's lace handkerchief. Bulk pkt. 10c; 1-16 oz. 15c.

Marigold Old-fashioned fiower blooming in protill frost comes. Bulk pkt. 5c; 1-16 oz. 10c.

Mignonette A well-known hardy annual, proers. Seed sown in autumn will bloom early in the spring; thrives best in cool temperature: 1 foot high. New Machet. Mixed sorts. Bulk pkt. 5c; 1-16 oz. 10c.

Mourning Bride (Scabiosa) A half hardy plant places. Flowers borne on tall, slender stiff stems with fine, round, full centered form of tubular petals with feathery effect. Michael's De Luxe Mixture. Bulk pkt. 5c; 1-16 oz. 10c.

Moonflower (Noctiflora) A wonderful climbto the height of $20 \mathrm{ft}$. in a single season. Foliage large. dense and luxuriant. Splendid shade for porches. Flowers open at sundown and like all night bloomers has a delicious fragrance. Bulk plet. 5c; 1-16 oz. 10c; 1/4 oz. 25c.

Morning Glory Handsome, showy climber, suittrellis, trellis, old stumps, etc., if support be given the vines. Hardy annual. 10 feet high. Giant Japanese Mixed. Bulk pkt. 5c; 1-16 oz. 10c.

Pinks (Heddewigi). For beautiful and lasting of bloom, the hardy garden pinks have no superior among annuals; 18 inches high. Michael's Chinese DeLuxe Mixture. Bulk pkt. double, 5e; 1-16 oz. 10c. Single, 5e; 1-16 oz., 10c.

Everblooming (Pink) Single mixed. Bulk Everblooming (Pink) Double inixed. Bulk

Great advance has been made in re-

Poppies cent years in the development of the Poppy. No other flower produces a more brilliant display of colors during the blooming period.

SHIRLEY POPPIES. Michael's DeLuxe Mixture. Bulk pkt. $\check{5 c}$; 1-16 oz. 10c.

TULIP POPPIES. (Shirley type). Intense scarlet. Bulk pkt. 10c; 1-16 oz. 15c.

AMERICAN LEGION. (Shirley type). Dazzling intense scarlet. Bulk pkt. 10c; 1-16 oz. 15c. DOUBLE PEONY FLOWERED. Mixed. Bulk pkt. 5c; $1-16$ oz. $10 \mathrm{c}$.

DOUBLE CARNATION FLOWERED. Mixed Bulk pkt. 5c; 1-16 oz. $10 \mathrm{c}$.

Portulaca or Rose Moss flowere are but few that make such a dazzling display of color in the bright sunshine as a bed of Portulacas. The flowers close in shadow but are open in sunshine.

PORTULACA. Single Mixed. Bulk packet ธิс: 1-16 oz. 15c; 1-8 oz. 25 .

PORTULACA. Double Mixed. Bulk packet $15 \mathrm{c}$; 1-16 oz. $25 \mathrm{c} ; 1-8$ oz. $40 \mathrm{c}$.

Phlox (Drummondi). The Phlox is the earIt occupies a most prominent place in the flow:

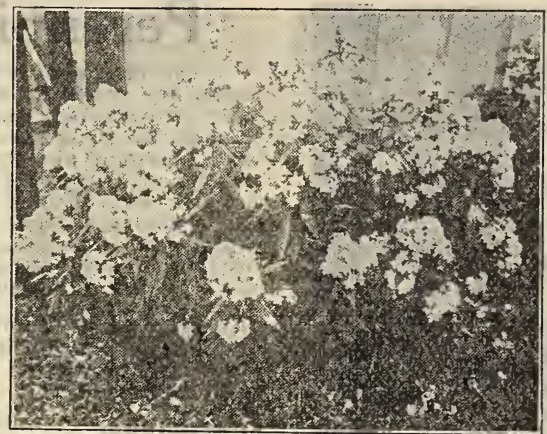

Phlox Drummondi

er garden and produces a variety of flowers of beautiful colors, which is varied with stripes, veins and points of contrasting shades. Michael's DeLuxe Mixture. Bulk pkt. 10c; 1-16 oz., 15c; 1-8 оz. 25c.

Salvia Among the most brilliant colored flow Salvia ers and extremely useful for bedding. Blooms are of fiery red crimson color, continuing to flower for a long time. Tender perennial; blooms until frost; height 2 to 3 feet. See page 19 for plants. Salvia Splendens. Bulk pkt. $10 \mathrm{c} ; 1-16$ oz., 25e; 1-8 oz., 40c; oz. \$2.50.

Salpiglossis Very showy bedding or border plants, with richly colored, funnel-shaped flowers, which are purple, scarlet, crimson, yellow, buff, blue and almost black: height, 1 foot. Fine Mixed Sorts. Bulk pkt. 5c; 1-16 oz., 10c.

Stocks To such perfection has selection brought large proportion of exceedingly double have a ers. Average height, $1 \frac{1 / 2}{2}$ feet. Double Mixed, Buik plkt. 10c; 1-16 oz., 25e.

Sweet Williams For display in the garden, the sed. The seed can be planted in the spring in the open ground and will blossom in the fall Hardy perennial; $1 \frac{1}{2}$. feet high. Fine mixed single. Micliael's Double DeLuxe Mrixture. Bulk pkt. 5c; 1-16 oz. $10 \mathrm{c}$.

Newport Pink (Sweet William): A distinct brilliant and beautiful. Bulk pkt. 15c; 1-16 oz. 40c.

Snapdragon (Antirrhinum Medium). For gorgon eous coloring effect, few flowers surpass the Snapdragon. Borne on long stems and very fragrant. Michael's DeLuxe Mixture. Bulk pkt. 5c; 1-16 oz., 10c.

DEFLANCE. Fiery Scarlet. Medium. Bulk packet 5c; 1-16 oz., 15c.

GRENADIER. Orange Scarlet. Bulk packet 10e; 1-16 oz., $15 \mathrm{c}$.

PRIMA DONNA. 'Terracotta. Bulk packet $10 \mathrm{c} ; 1-16$ oz. $15 \mathrm{c}$.

Verbena Sown in May, they will bloom in in pots in winter, they will bloom sooner. Seeds should be soaked in luke warm water before planting and care should be taken that the soil be very rich. Half hardy perennial trailer; 6 to 10 inches high. Michael's Deluxe Mammoth Mixture Hybrida Giganta. Bulk pkt. 10c; 1-16 oz. $25 \mathrm{c} ; 1-8$ oz., 40c.

Lucifer (New) Brilliant scarlet, no eye, an Im25c; 1-8 oz., 40c.

Firefly Brilliant Scarlet with a white eye. 


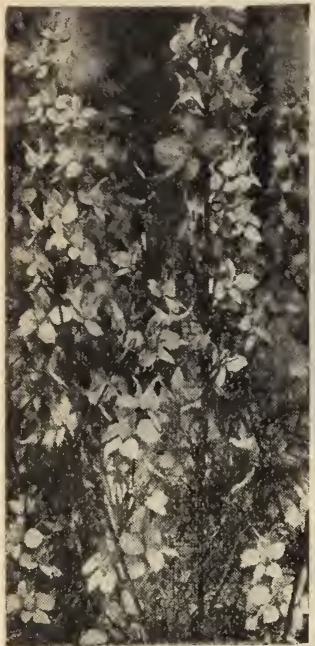

Helghinium

\section{Perennial Plant Flower Seed}

The charm of Peremial Flower Plants is that these occupants become onr truest friend,-once established the flower remains as long as they are wanted, anrl year after year we greet them at the same time and in the same place,-each flower has its season when it buds, bloows and blossoms and finally exhausts its glory and retires for a long winter's rest. There is no phase of ornamental gardening that deserves greater study. The economical way to obtain perenilials is to grow thein yourself from seed; they can be planted anytime from April to July,-the earlier sown ilie stronger the plants or clumps will be. Few of the perennials bloom before the 2 nd year but after that we are repaid each year for the care given them by the increasing wealth of bloom.

Aquilegia (Columbine). The Columbine is one of the most beautiful ft. stems. hardy perennials producing graceful spurred flowers on 15c; 1-16 oz. 50c.

Campanula (Canterbury Bells). A large flowering, beautiful and from 18 to $2 t$ inches in height. Michael's Deluxe Mixture. Bulk pkt. 10c; 1-16 oz., 25c.

Campanula Pyramidalis (Chinese Bell Flower). A beautiful, stateered with silver shaped white flowers from July until late autumn. Price: Packet 15c; 1-16 oz. 35c.

Carnation (Hardy pereunial variety). Some varieties of Carnation are most severe winters. Large double flowery, Dwarf mixed. Bulk put. 15e; 1-16 oz.. 25c. Hardy Grenadin Red. Bulk pkt. 15c; 1-16 oz. 35c. Delphinium (Perennial Larkspur). Few plants are so handsome in the garden as perennial Larkcolor. Michael's Deluxe Mixture of gold medal hybrid. Bulk packet 15e; 1-16 oz. 35c.

Dianthus Barbatus (Sweet William). An imDianthus Barbatus nrovement on the old fashioned kind, color and size of flower. Michael's De Luxe. Bulk pkt. 15e; 1-16 oz., 25c.

Digitalis (Fox Glove). Stately, old garden favor Dite. For garden shrubbery borders and in suitable places, producing spires of blossoms of 3 to $5 \mathrm{ft}$. high. Michael's Deluxe Mixture. Bulk pkt. 15e: 1-16 oz., 25e.

Gaillardia (Blanket Flower). An easily grown plant in ordinary garden soin; most valuable perennials. Michael's DeLuxe new lybrids. Bulk pkt. 15c; 1-16 oz. 25c.

Gypsophila Graceful plants of light fairy-like growth, bearing small white sprays. Mnch in demand for cutting and combining with other flowers for bouquets and vases. 10c; 1-16 oz. 25c.

Hollyhock One of the old-fashioned perennial flow-

DOCBLE MIXED. All kinds, beatiful array of colors. Bulk packet 10c; 1-16 oz, 25c.

ALLEGHENY. Single, mannoth flower, select flistening petals. Bulk packet 10c; 1-16 oz. 25c.

Papaver (1'erennial Oriental Poppy). For gorge. Papaver ous color the Oriental Poppy has few rivals among all hardy plants. Effective in shrubbery and Herbacevis borders. Michael's DeLuxe Oriental Hybrid Mixture. Bulk pkt. 15c; 1-16 oz. 25c. Phlox (Decussata). Hardy variety, with seed Phlox (Decussata). Hardy to germinate; should be well soaked before planting. I3ulk pkt. 15̃c; 1-16 oz. 35c. Platycodon (Chinese Bell Flower). Very handsome the flowers of which when in bud have the appearance of an inflated balloon blooming from June to September: large handsome deep blue flowers. Bulk pkt. 10c; 1-16 oz. $15 \mathrm{c}$.

Shasta Daisy, Alaska (Chrys Lancanthemum) Daisy with flowers of the purest glistening white, borne on long stems, a splendid cut flower, good for ten days. Bulk packet, 10c; 1-16 oz. 25c.

Sweet Peas (Lathyrus Latifolius)-A hardy ily. A showy, free flowering, blooming all summer, decorative vine. Fine for cut flowers. Select mixture. All colors. Bulk pkt. 10c; 1/8 oz. 25c; oz. \$1.25.

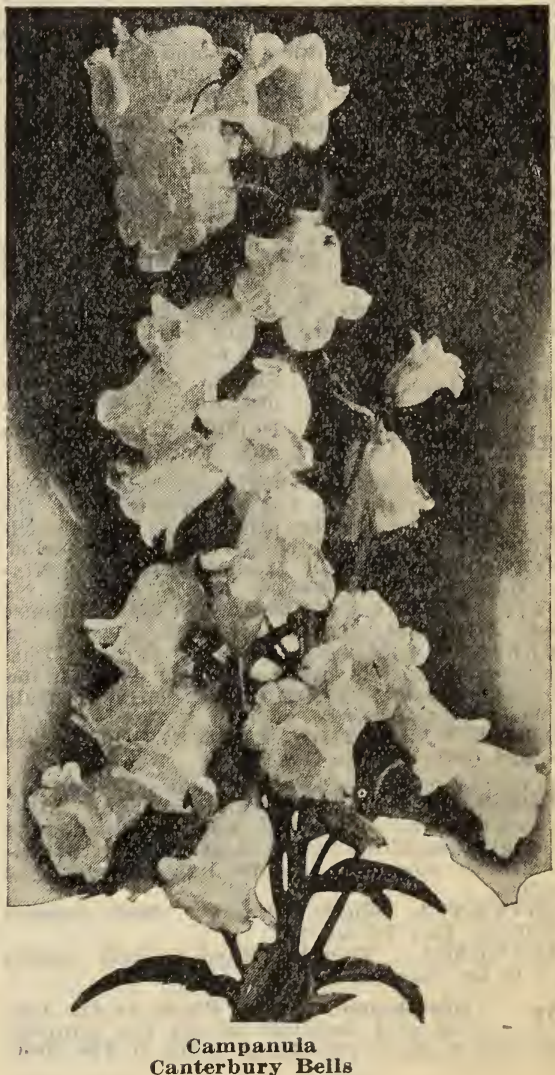




\section{ALFALFA AND CLOVER SEED}

CAUTION. It is fully as incumbent upon the part of the buyer to see that he gets what he bought as it is upon the part of the seller to exercise every caution and care to furnish what he sold. Mistakes occur in the best regulated business. The buyer should therefore check his pur-

chases over, examine it carefully just before planting, and know positively that all is correct.

REMFMBER, all prices we are quoting on these seeds are subject to market changes without notice. On all quotations cotton grain bags extra, 50c each.

\section{ALFALFA SEED}

This grand forage plant is now a success everywhere. The plant grows, thrives and does well on any of the rolling prairies or well-drained bottom lauds. The young plants are tender; the seed should not be sown until the frost has left and the ground is warm. One bushel of 60 lbs. will sow three to four acres. Can be planted with a light uurse crop of barley, speltz or wheat, but best results when planted alone. The stock we handle is northern grown native seed.

Common Alfalfa The native variety that has planting and not otherwise known which we find in Dakota, Montaua and the inter-mountain country. Price per bushel, \$12.50 to $\$ 14.00$. Fancy to Superfine.

\section{DAKOTA GROWN ALFALFA}

Dakota No. 12 is the Alfalfa of the common variety which has been grown in the state of South Dakota for at least twentyfive years continually, season after season. Constitutes what is known; according to the Dakota Agricultural College as Dakota No. 12 to distinguish it from that which has not this continuil parentage. Per bushel, $\$ \mathbf{1 5 . 0 0}$.

\section{Turkestan Alfalfa peed of this variety is} imported only from that country. American relations with the Soviet is such that there will not likely be any imported this year. Price on application.

Grimm Alfalfa A very hardy, acclimated strain roots are more or less of lateral tendency, and do not consist entirely of one straight tap root. For this reason it is desirable for land having a hard sub-soil, which is difficult for the roots to penetrate. Certified Seed, Dakota grown, $\$ 37.50$ per $1001 \mathrm{lbs}$.
Canadian Variegated Alfalfa This is a variety that has dereloped, it seems, in the Canadian province of Ontario of lost origin, but doubtless from its peculiar features, is of Grimm parentage. At the Iowa Agricultural College, experimental plats for hardiness and durability, tests equal to Grimm if not superior in this respect. Different from other varieties of alfalfa that come to seed only in more arid sections of the country, this Canadian variety seeds very readily and to advantage in the above mentioned province of Canada. The seed of this variety that we offer for sale is raised in the province of Ontario, Canada and imported from there in staled bags which is assurance that the seed we offer is the genuine article. As a forage plant it produces foliage equal to Grimm, very deusely leaved and as pasture product is highly recommented. Price per pound, fancy seed, 30c; per 10 Ibs. $\$ 2.90$; per 100 lbs. $\$ 28.00$.

Cossack Alfalfa This a variety introduced by 1he Dakota Agricultural College, discovered by Prof. Hanson, growing in Northern Siberia, and having endured that climate for ages, is an arctic variety which he highly recommends as the most hardy Alfalfa in the world, recommends it also as a valuable forage producing variety. Price per lb.; 10 lbs. $\$ 4.25$; per 100 lbs. $\$ 40.00$.

\section{SWEET CLOVER SEED}

There are several varieties of this once much despised, but now most popular forage plant and land fertilizer. All the varieties we handle are well suited to our section of the country. Absolutely harly anywhere in the United States or Canada, most of which are biennial but there is an annual sort known as Hubam, but little used.

Dwarf White (Grundy) A variety of late iniginated in Grundy County, Illinois and somewhat different in several respects from the tall growing Commou White. Aside from having the good qualities of the Common, it branches out lower on the stalk, produces a denser foliage, does not grow so tall, matures earlier and more miformly than the big Common, stems not so coarse either as that sort. Requires no clipping and is easily handled with a grain binder. The seed matures much earlier, more evenly, and the berries are smaller and therefore do not require so much to seed an acre and also as a seed proposition is far more prolific than any other varieties known. Price per $\mathbf{l b}$. 20c; per $10 \mathrm{lbs}$. \$1.\%5; per 100 lbs. $\$ 15.00$; per bu. $\$ 8.50-\$ 9.00$. Fancy to Superfine.

\section{RED, ALSIKE AND WHITE CLOVER}

Medium Red Clover This by far the most important of all the varieties for practical purposes. Sow in spring or fall, and if no other grasses are used, at the rate of 15 pounds per acre... More is used on old soil than on new. Per bu. \$24.00.

Mammoth Red or Sapling Clover (Trifolium Similar to Red Cratense). Similar to Red Clover, but coarser, taller and more hardy. Sow from 12 to 15 pounds per acre. Price \$24.00.
Common Yellow (Biennial) Preferred where denser foliage is desired as a hay proposition and is said to be equal to the Common White as a pasture proposition. If left to seed a greater yielder than the Common White as a seed crop. Price, $\$ 8.00-\$ 9.00$ per bu. Fancy to Superfine.

Common White (Biennial) Preferred where taller growth of foliage is desired as humus matter in connection with fertilizing or heavy coarse forage. It makes a splendid pasture as well as hay crop when the latter is harvested at the right time. Price \$8.00$\$ 9.00$ per bu. Fancy to Superfine.

\section{Hubam Sweet (White Annual) This variety is much like the big biennial Common White except that it} seeds the same year it is planted. Price 25c per $\mathbf{l b}$.

\section{See Page 46 for Nitragin cultures, inoculation for Alfalfa, Sweet Clover and other legumes.}




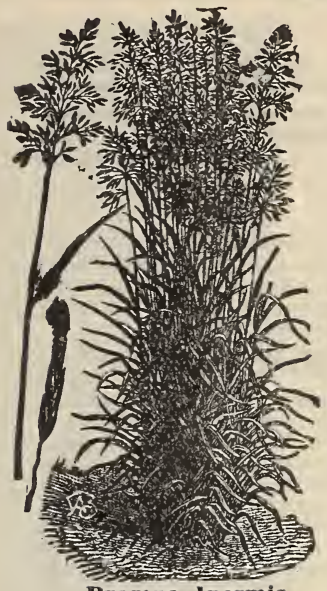

Bromus Inermis

\section{BROMUS INERMIS (Awnless Brome)}

This is one of the hardiest varieties of cultivated grasses. The latest to lose the luscious green foliage as the winter comes on and first to carpet the ground with a coat of green when the breath of springtime awakens plant life. Of Russian origin and has deep, dense roots that make a powerful sod. Stands extremes of heat and cold far better than most any other grass known. A protection against washing on terraces by streams or river banks. Highly recommended for our semi-arid region of the west as well as moisture climates. It grows with wonderful rapidity. Density of foliage at the base, making a luxuriant pasture grass and is used as a hay crop as well. Analysis of its feeding properties show it is rich in flesh forming ingredients. Seed is light and flufify, weighing $14 \mathrm{lbs}$. to the bushel. Sown at the rate of 15 to $20 \mathrm{lbs}$. per acre, either in early springtime or late summer, early fall. Price: Per lb. postpaid 25c; per bu. of 14 Ibs., $\$ 2.00$. $\$ 10.00$ to $\$ 12.00$ per 100 . Burlap bags free.

\section{Timothy}

TIMOTHY. This well- known grass is the best of all grasses for hay. Succeeds very well on all kinds of soil, but is well adapted to moderately moist land. Should be cut just when the blossoms begins to fall. Can be sown in spring or fall. One bushel sows 3 acres. Is used in mixture with clover and other grasses to good advantage. We quote subject to market change, super-fine quality, per bushel, \$3.50. Bags extra, 50c each.

\section{Kentucky Blue Grass}

The universal pasture grass of America and the flnest lawn grass in the world is our own Kentucky Blue Grass.

It starts like magic with the first smile of spring and is a velvet green until winter comes. It can be grown on the wild prairie and will catch, but the best results are to be had by geting the seed well mixed with the soil. The seed we offer is frosh, clean and pure. Sold at rate of 14 lbs. per bushel, which we quote subject to market changes, 21 lbs. quality, $\$ 4.00$ per ba... For lawn culture, double weight, our Purity Brand, 30 lb. qua'ity; 100 per cent pure, highest germination, 75c per 1b. postpaid. All prices subject to market change.

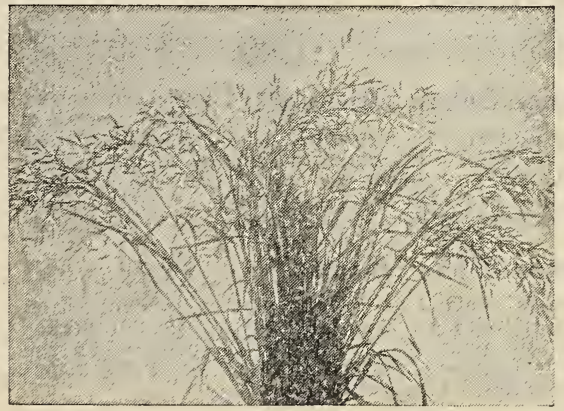

English Blue Grass

\section{Orchard Grass}

Orchard Grass. This grass does well everywhere, and for hay can be cut much earlier than timothy. Succeods the best of grasses in tim. bered lands or orchards. Sow one to two bushels per acre. Per Ib. postpaid, 35c; bu. of 14 lbs. \$2.50.

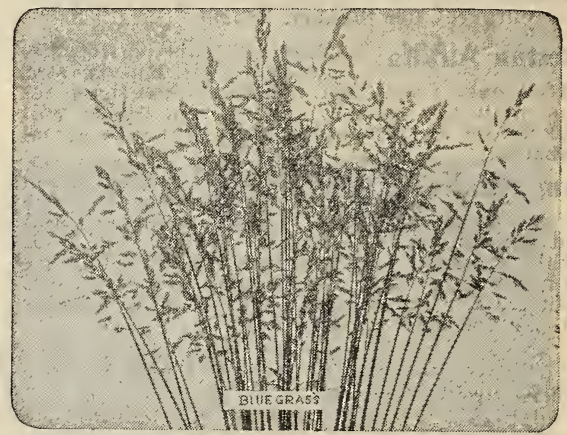

Kentucky Blue Grass

\section{English Blue Grass}

It is a success everywhere, on all kinds of land and never freezes out. It comes early in the spring, is green all summer and lasts until late autumn. It's an early quick crop and a nutritious pasture grass. It's a perennial, 2 to 3 feet high, and heads ont in June. About 15 lbs. per acre. Best seed, per 1b. postpaid, 40c; per 100 lbs. \$25.00. Burlap bags free.

\section{Red Top}

Rerl Top. This grass is especially suited to low, wet, spouty lands; is in fact, the only grass which is a real success on such soil. Stands our northern winters, can be sown on wet land without cultivation, and will catch. Into the wet soil it spreads its net-work of roots, tames the land, and in a few years makes a deep, substantial sod. The seed often comes in the chaff, but the only thing to plant is the solid seed, clean from chaff. Sow 10 pounds per acre. We quote best solid seed, very best, per lb. 60c, postpaid; per 100 lbs. \$35.00. Our cotton bags extra, 50c each.

\section{Rye Grass}

This grass, though but an annual in this climate, in a very short time after the seed is sown it makes as tine pasture as other grasses of long standing. The leaves are very dark green with a rich lint to the blade. It makes a pasture quick as oats or rye would, and being a grass is of far greater value. It makes a splendid winter pasture if left to cure on the ground. Lb. postpaid 25c; ber 10 lbs. $\$ 2.00$; per 100 Ibs. $\$ 12.50$. Burlap bags free. 


\section{FORAGE AND FIELD SEEDS DEPARTMENT}

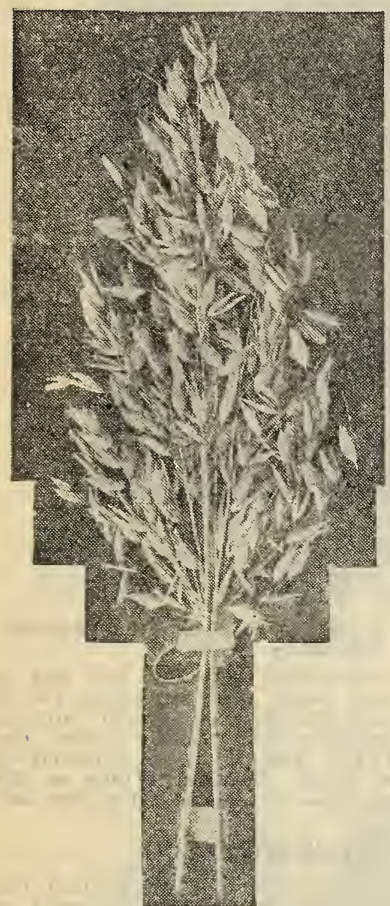

\section{German Millet}

Pure German Millet of all the well-known kinds, is by far the most valuable. This well known sort reaches the acme of perfection in the more southern states, and it is a fact that when the southern grown seed is planted in the north, it produces a taller stalk, and heavier growth of foliage than can possibly be raised from our own northern grown seed. Plant three-fourths bushel per acre. Price: $\$ 2.50$ per bu. Bags extra, 50c each, holding $21 / 2$ bu.

\section{Sugar Cane and Fodder Cane}

The greatest of all forage and fodder plants. It will yield two crops of fodder and a good fall pasture in one season. Roots deep into the eubsoil and stands the drouths that often destroy other crops. As a rough provender it is unsurpassed. Sow 1 to 2 bushels per acre. Subject to market change, Early Amber at $\$ 2.50$, and Mixed Fodder at $\$ 1.50$ per bu. bags extra, 50c. Special prices in quantity on application.

\section{Sudan Grass}

What U. S. Department of Agriculture thinks about Sudan Grass. That it is a tall annual grass. growing when sown broadcast, to height of 4 to 6 feet. It stools abundantly, as many as 100 stalks coming from a single root. Ylelds two cuttings in one season. It is a marked success, especially in semi-grid sections of the West. Drilling Northern grown Certified seed or broadcasting, 15 to 20 pounds per acre. Shortage of seed this year reported from Kansas and other southern seed crop districts. 100 1b8. for \$7.50. Bags extra, 50c each, holding $21 / 2 \mathrm{bu}$.

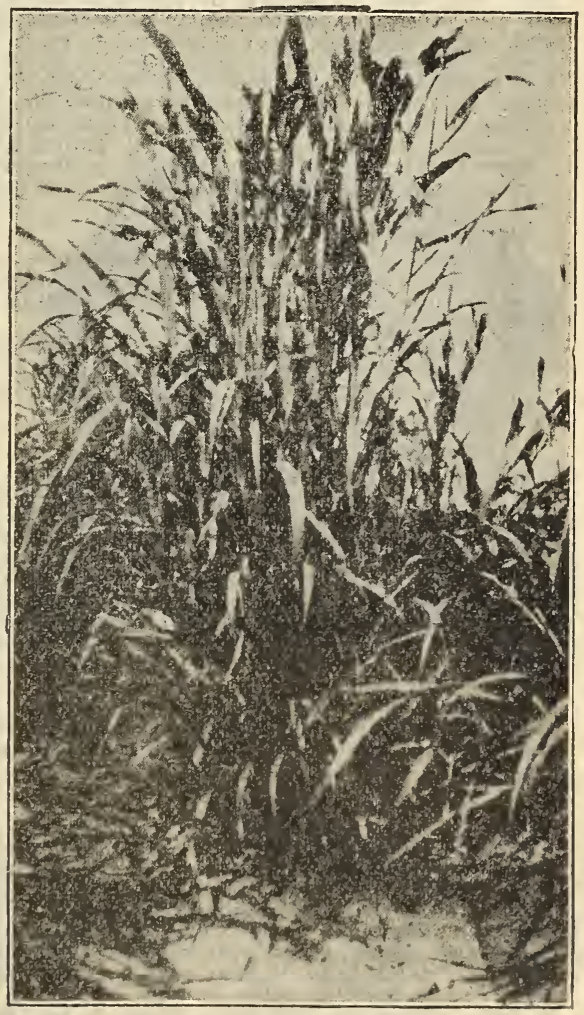

Sudan Grass 


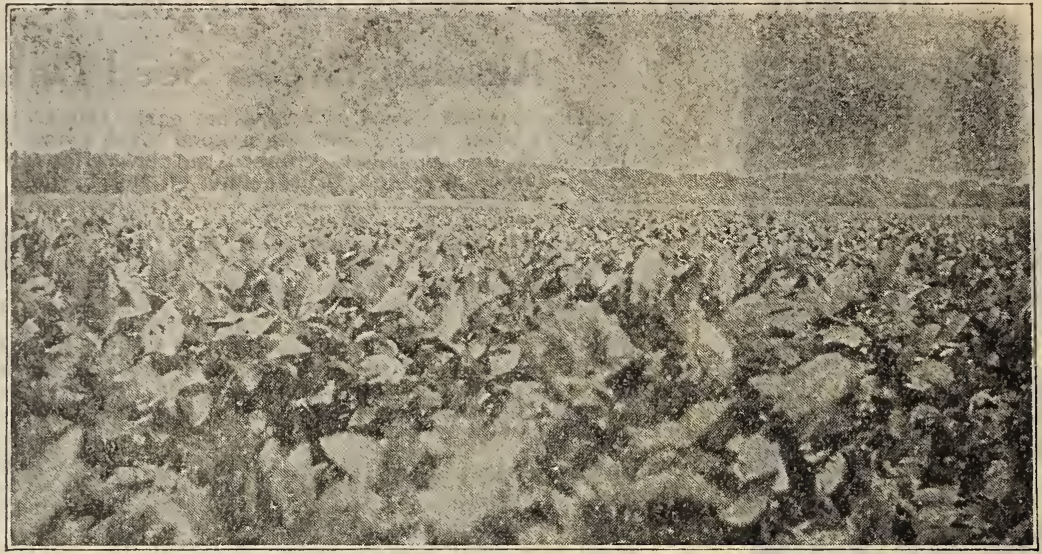

Soy Beans

\section{Soy or Soja Beans}

Northern Grown. Valuable for hay or soiling food for cows, hogs and sheep pasture, also green manurc. They resemble the navy bean in general appearance. Like clover they are great soil enrichers, gathering in nitrogen from the air and storing it in the soil. Many tests show that they may be grown wherever corn will ripen. When planted after corn in rows $2 \frac{1}{2}$ feet apart with. 6 to 8 plants to the foot of row if grown for the beans, requiring about one-half bushel of seed per acre when planted from planter attachment with corn 1 bushel plants about 8 acres. When grown for hay, it is preferable to plant the rows closer together or sow broadcast, at the rate of $40 \mathrm{lbs}$. per acre.

Prices subject to market change.

MANCHU. Iowa grown, half peck, 55e; peck \$1.25; bu. \$2.50. Burlap bags free. American cotton grain bags extra, 50c each, holding $21 / 2$ bushels.

MANCHCRIA - Week earlier than Manchu which we offer at the same prices as the Manchu.

ITO SAN, Iowa grown, half bu. $\$ 1.40$; bu. $\$ 2.50$. Burlap bags free.

\section{Ruby Spring Wheat}

A new variety of wheat introduced recently which has given unqualified satisfaction wherever it has been grown. It is somewhat similar to the type of Marquis; in fact quite so. Equal to it in milling qualities but far superior to it in earliness, being ten days to two weeks earlier. It misses the hot winds that affect later varieties and often ruin the crop and the rust too that often happens to catch the late varieties. It yields a third more to the acre than most of the other varieties of spring wheat. Earliness and yield are highly recommendable virtues. Price $\$ 2.50$ per bu.; 10 bu. at $\$ 2.25$ per bu. Sacks extra, 50c each.

\section{"Speltz"}

SPRING EMMER. A grain especially suited to dry lands. Being semi-hardy, it can be sown very early in the spring like oats. Emmer grows best in the dry prairie regions with hot summers, and even does well in poor or stony ground. It is a better drought and rust resister than either Oats or Barley, and it also yields considerably better. The feeding value is high. Sow $1 \frac{1}{2} \mathrm{bu}$. to acre. Price bu. (40 lbs.) \$1.40: 5 bu. $\$ 6.00$. Burlap bags free.

\section{Feterita}

A Variety of Kaffir Corn, the New Drouth Resisting Plant

Feterita was introduced recently and has already in one year made a great name for itself in the drouth stricken southwest country. It is 25 days earlier than Kaffir Corn, outyield Kaffir by far and is little affected by drouth. Per bu, \$2.50. Regular White or Red Káffir Corn at $\$ 1.75$ per bu., bags extra, 50c each.

\section{Buckwheat}

This is very valuable for use on ground that cannot be seeded until late in the summer, as it can be sown as late as July 1st and still makes a good crop. Per bu. $\$ 1.50$. Bags extra, 50c each.

\section{Winter Rye}

FOSEN RYE. This is a variety of recent introduction by the Michigan Agricultural College. It is a stiff-strawed, hardy, white winter variety of wide adaptation. It is developed from Russian parentage. Has large, white kernels, yielding in abundance. \$1.35 per bu.....American grain bags, 50c each, extra.

\section{SPRING RYE}

SPRING RYE. A good eatch crop, as it may be sown later than most grains. Not so good a yielder as IVinter Rye but matures a crop of grain like Spring wheat the same year it is sown. Sow about $1 \frac{1 / 2}{b u}$. per acre. Crop is very short. Price, peck 65c; bu. \$2.00; 10 bu. \$17.50. Bags 50c each.

\section{Barley Seed}

SIX ROWED. There are many who want to obtain or change their seed of barley, but who do not want to pay the price necessary to ask for the newer sorts. This is a good standard sort. Price on application.

\section{Flax Seed}

NORTH DAKOTA CROP SEED (Minn. 25) A wilt resisting Flax which is a selection made by the Minnesota Experiment station from stock received from the department of agriculture at Washington. Fine seed recleaned for seeding rate of half bu. per acre. Price on application. Bags extra, 50c each. 


\section{Canadian Field Peas}

This is the variety of peas grown so extensively in the North and Northwest as a field crop. They are somewhat similar to the ordinary garden pea, but make longer vines and more pods. They should be sown very early in the spring, either alone or with oats or barley at the rate of from one to two bushels per acre. They may be cut and cured for hay or let ripen and thresbed like small grain. Price subject to change per lb. 10c; per 100 lbs. $\$ 8.00$. Bags extra, 50c each.

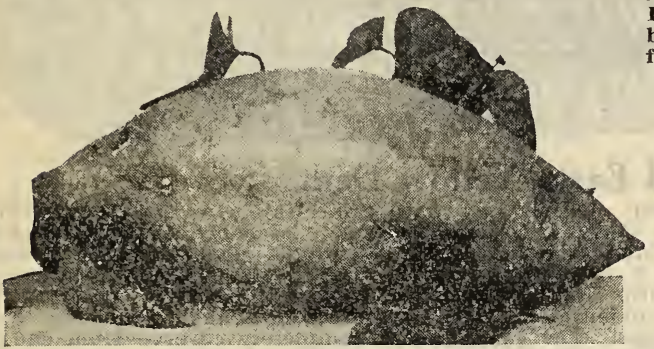

Yellow Jersey

\section{Dwarf Essex Rape}

Au annual plant of the cabbage family, grows very quickly in any weather and makes a big, loose bunch of leaves, somewhat like cabbage leaves, but long and narrow; grows all summer without going to seed. When eaten off it sprouts up from near the ground. All kinds of stock eat it readily and thrive on it, but most valuable for hogs, especially young stock. Broadcast, 5 lbs. per acre on well-prepared land, early in the spring, and after it gets started it will keep a dozen shoats to the acre all summer without other feed. Price subject to change. Per lb., 15c; per 100 lbs., $\$ 10.00$ in original heavy burlap bags of $220 \mathrm{lbs}$, each; $\$ 18.00$ per sack; bag free.

\section{SWEET POTATOES}

\section{Grown Especially for Seed}

The potatoes should be planted in a well prepared hot-bed. We can offer Yellow Jersey (the most popular Northern sort). Lb. 15c; 15 lbs. \$1.25; per measured bushel, \$2.50. Write for special prices on quantity. We grow sweet potato plants. Price per 100, 75c; 500, $\$ 3.75$; per $1000, \$ 6.00$.

\section{SEED POTATOES}

All These Prices Subject to Market Changes

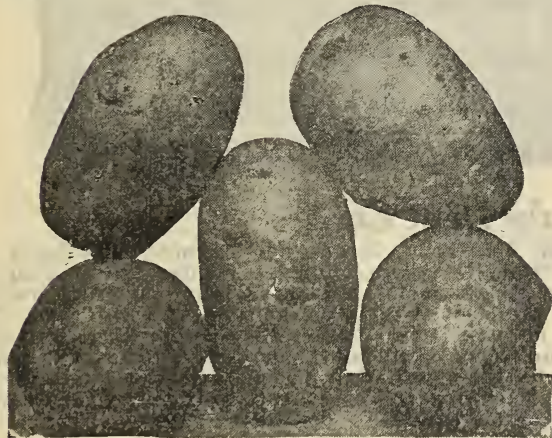

Red River Early Ohio

Red River Early Ohio The stock of Early rrown in the Red River Ohio we offer is They are from ten days to two weeks earlier than common stock; are pure bred and free from scab, and were raised especially for seed. - If you want something earlier than anything else, don't fail to get a few bushels of these choice earliest. Price per bu. $\$ 3.00$.

Irish Cobbler Potato One of the most valutoes. Very productive, globular in form, uniform in size, pure white. Per bu. \$3.50.

Red River Triumph The Triumph is the The tubers are nearly pound, smooth, medium in size, reddish pink in color. Price: $1 / 2$ bu. $\$ 2.00$ : per bu. $\$ 3.50$.

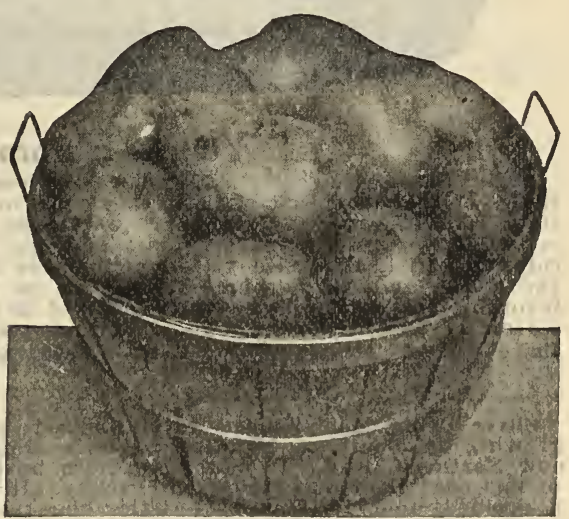

Carman No. 3

Carman No. 3 This potato is of large and mense crops. It is of perfect form. It has but a few eyes, and they are shallow; the skin and flesh are extremely white, and its cooking qualities are very fine. It is a remarkably liandsome potato, enormously prolific. Per bu., $\$ 3.50$. 
TIPPED

SELECTED

SEED CORN DEPARTMENT

TESTED AND

GRADED

Our seed corn is grown here in the North, acclimated, selected and tested. We give no guarantee of crop, either expressed or implied, or guarantee of any kind, but if anyone wishes to test our seed corn before planting and is not satisfied with the test, he can return the seed and get his money back. American Cotton grain bags extra, 50c each. Burlap bags free. Todays prices, Dec. 1, 1926 ALL PRICES SUBJECT TO MARKET CHANGES. Write, phone or call for price on quantity.

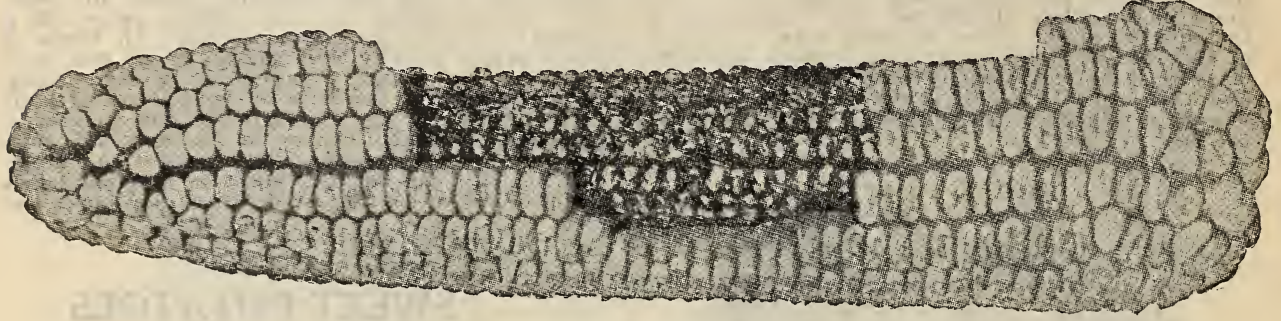

Reid's Improved Early Yellow Dent

This particular strain of Reid's Yellow Dent corn is known in this locality as the Forb strain. It was bred up by selection for some 8 or 10 years for earliness until the early feature for this climate was thoroughly established and has taken the first prize for Reid's corn for well matured earliness, at the Nebraska State Fair for some 4 or 5 years and the best strain without question of that well known sort for the climatic condition of northwestern Iowa and surrounding country, that has ever been developed. It has a rich golden color. The ears are 9 to 11 inches long, 18 to 24 rows of kernels, each containing 50 to 60 grains. The cob is small completely covered from end to end with solid deep kernels of corn. The kernels are rather narrow, medium in thickness, knit very closely together on the cob with no lost space between the rows and of all corn grown in this part of the country, it is the easiest to shuck. Price per bushel, shelled, \$3.50; 5 bushels, \$16.00; select ears, on ear \$4.00. Todays prices, Dec. $1,1926$.

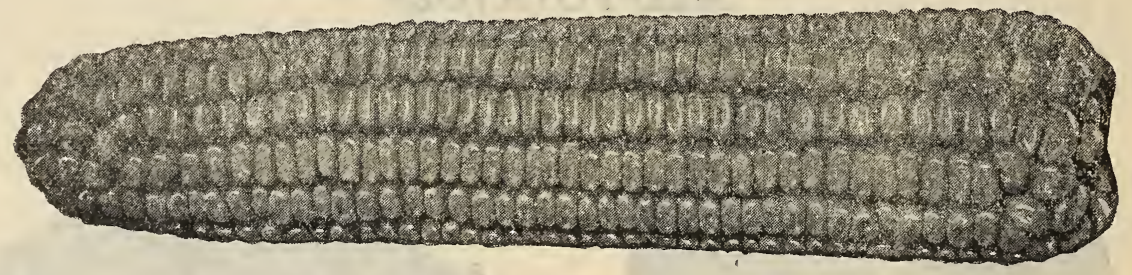

\section{Yellow Hammer Early Dent Corn}

This variety is early as 90 days or less, yellow field corn, is one of the most surprising varieties of that kind that we have ever come in touch with. It is an immense yielder for another variety of field corn. The ears are not large, nor are the kernels as deep as later varieties, but the ear is fair sized for an early sort and the kernels are deeper than the kernels of Flint corn. The color is a rich attractive yellow and makes a most popular sort. The stalks are not large but stout and stocky and can be planted closer in the row than other sorts and has been known to yield in favorable seasons, as much as the rate of 75 bushels to the acre. Can be planted the latest in the season of any variety we know of and yet matured before the frost comes in early September. Price per bu. shelled, $\$ 3.50 ; 5$ bu. $\$ 15.00$; select ears, on ear, $\$ 4.00$ per bushel.

\section{Silver King}

Silver King has almost revolutionized corn growing in Southern Minnesota, South Dakota and Northern Iowa. It will yiold more bushels of fine corn than any other dent variety. It has a decided double-ear characteristic, one reason for its fine yield records. Per bu. shelled, \$3.50; 5 bu. $\$ 15.00$.

\section{lowa Silver Mine}

Iows suver Mine. This is more generally grown throughout the corn belt and more widely and favorably known than any other white gorn. It is a sure cropper, middling early, deepgrained, pure white, and a good corn In every way. Per bu., shelled, \$3.50.

\section{Popcorn}

Japanese Rice-A short eared heavily yielding variety of hulless popcorn. Price on ear per $\mathbf{l b}$. 15c; 10 lbs. $\$ 1.25$.

We have other varieties of field corn and shall be pleased to quote prices on application for any other variety suited to our climate. All prices subject to market changes.

WE RESERVE RIGHT TO FILL ORDERS AT PRICES ON DAY SAME IS RECEIVED. 


\section{DEPARTMENT OF BULBS, ROOTS AND FLOWERING PLANTS} Peonies

Peonies. These big hearted flowers are as much liked today as they were by our grandfathers a century ago. Peonies will grow and do well anywhere ple plant will grow. Give them a deep, rich soll, plenty of barnyard manure, or better still, manure from the hen house, and they will repay you one hundred fold. The Peony, once planted, lasts a generation and grows better every year. They are perfectly hardy and need no winter protection whatever.

Festiva Maxima Globular large white flowers, combining enormous size with wonderful beauty. Often 8 inches across. The plant has erery point of perfection. Most healthy and powerful grower of any variety. The pure white flower is flecked with crimson in the center. Forty inches high; 3 to 5 eye roots, $40 \mathrm{c}$ each. 3 for $\$ 1.00 ; \$ 4.00$ per dozen. Undivided clumps, 3 years old, $\$ 2.00$ each; 3 for $\$ 5.00$.

Edulis Superba Exceedingly fine, vivid roseEdulis Superba colored flowers, high, full center, very compact, very early and free blooming, highly perfumed. The best fragrant rosecolored peony. 3 to 5 eye roots. Price: $35 \mathrm{c}$ each. 3 for $\$ 1.00$. Undivided clump, \$2.50.

Felix Crousse. The ideal self-colored red Peony: large, globular and compact, an even shade of bright red without trace of any other color; a strong, vigorous grower. 3 to 5 eye roots. Price: 75c each; 3 for $\$ 2.00$. Large undivided clump, $\$ 3.50$.

Golden Harvest Flower creamy jellow with carmine markings and blush clumps, $\$ 3.00$.

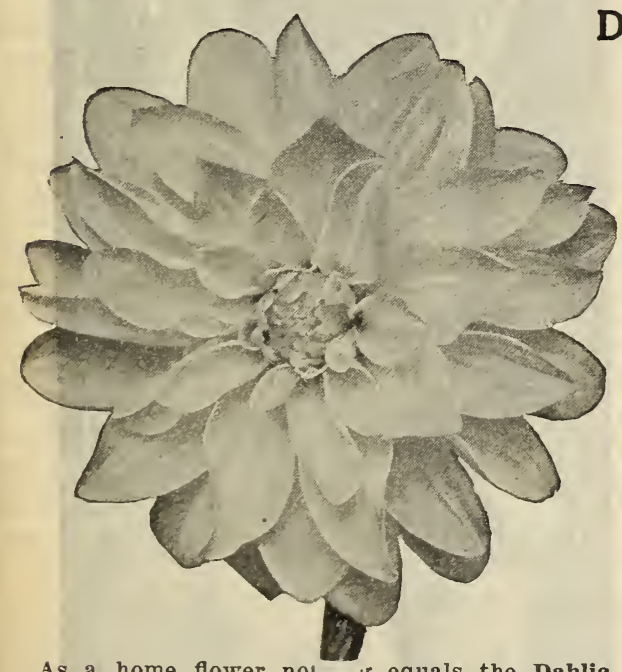

As a home flower nol..... equals the Dahlia. Plant the roots 2 feet apart, about 4 Inches deep, lay them flat on side.

American Beauty Brilliant, crimson red, rich shade to the American Beauty Rose. One of the most prolific bloomers ever introduced. Price, 25e each.

Souvenir Donzon (Decorativo). An immense flower with broad, flat pettoll to the center. The largest red in the decorative section. Price each. 25e.

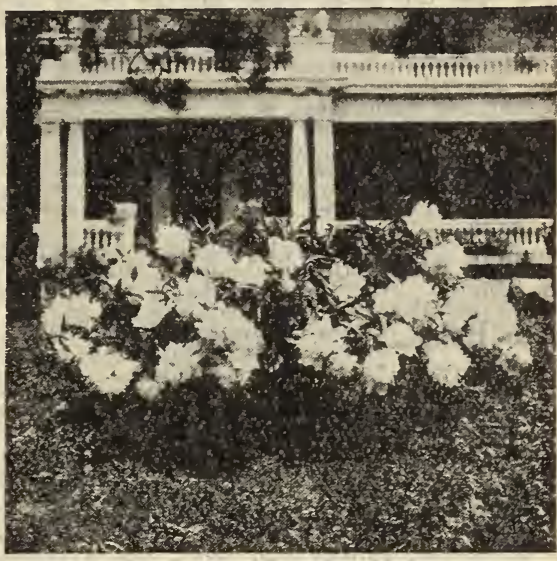

Festiva Maxima in full bloom

Rubra Superba Rich brilliant, deep crimson without center. Fragrant large clump flowers. Good bloomer and choice cut flower; tall and graceful. Very late, June 12th. 36 inches high. Three to 5 eye roots, 60c each; 2 for $\$ 1.00$; $\$ 5.50$ per dozen.

Mixed Peonies Our Mixed Peonies are made up of broken lots of our very best named varieties, some of which are worth five times the price we ask for them. Price: 25c each; 6 for $\$ 1.35$; per dozen $\$ 2.50$.

Dahlias

Purple Manitou Immense flower; often solid mottled with crimson; very attractive. Price, $25 \mathrm{c}$ each.

Tango Masterpiece A gigantic flower of clear, ing; borne on long stems. Blooms early and continuously through the season. Color, clear rich tango. It is indeed a masterpiece. Height. 4 feet. Price. $35 \mathrm{c}$ each: 3 for $\$ 1.00$.

Delice Its beautiful soft, jet lively color, a glowing rose-pink, together with its perfect shape, stout, stiff stems, which hold the flowers well above the foliage. Price 25c each; 3 for $70 \mathrm{c}$.

Moonbeam (1916). (Decorative). An immense Color, flower, borne on excellent stems. of the light yellows. Plant a sturdy grower. Blooms very freely and an excellent keeper when cut. Price, 25c each.

Gaiety A superb new decorative, vivid scarlet, are long and flowers are produced freely. Price, $25 \mathrm{c}$ each.

Mrs. Winters (Decorative). This superb white Dahlia is generally and favorably known. Always reliable, always satisfactory. As a white it has neither superior nor equal. Price: 25c each.

D. M. Moore (Show). A flower of mammoth size, produced in profusion on long, stiff stems, Its color is a deep, velvety maroon. It has no equal in its color. Prlce, each, 25c.

Souvenir Franz Liszt (Peoneo Nlowering). Veined and shaded with white. Flowers very large. Price, each 35c.

Mixed Sorts Various colors and kinds, mixed 


\section{Canna Roots and Plants}

The king of bedders. The plant requires deeply dug, well enriched soil. Plant when ground is warm. Set the taller kinds for the center and dwarf kinds for the outer edges. Canna plants ready about May 1 st. King Humbert (4 ft.) Bronze foliage. Velvety,
mine. heartshaped ears of a deep purple. Price: ner root, 15c each; doz., \$1.75.

Beacon ( 4 to $41 / 2$ ft.) Heavy, lateral growing rich green toliage. Flowers of very rich cardinal, which are produced in great masses. Its immense flowers with handsome foliage are very striking. Per root, $15 \mathrm{c}$ each; 3 for $40 \mathrm{c}$; doz., \$1.50.

Wyoming (7 ft.) Purple foliage. One of the most majestic Cannas. Blossoms orrounded petals. Per root, 10c; doz., \$1.00.

Queen Helen (Yellow Humbert). Identical with Queen Helen bronze King Humbert in growth. Flower pure jellow, sometimes dotted with red and sometimes the petals are red and yellow mixed. The foliage rich green. Size about $41 / 2$ feet. Roots, 15c each; \$1.75 per doz.

The President The best new Canna yet introduced, flowers a glowing scarlet of immense size; foliage rich green, broad leaf of lateral growing habit, borne on a stout, heavy stock about 4 feet high. This combination of flower, foliage and stock are qualifications of special value in the enchanting effect in any bed of Cannas. Roots 25e each, \$2.50 per dozen.

\section{Gladiolus Bulbs}

Musafolia (8 ft.) Green foliage with Bronze which on border. Grown for foliage only, leaves is used for making screens and backgrounds. Per root, 5c; doz., 50c; $100, \$ 3.75$.

CANNA PLANTS (Potted)

Canna Plants. The Canna is a tender, subtropical plant; roots easily affected by severe weather changes and often rot in the ground by being planted too early. The most effective way of planting them is to use plants which are started in a greembouse early in the season and in 4 in. pots having 2 to 5 leaves on thein by the first of May, at which time, weather permitting, they can be planted outdoors.

Wyoming, Tall bronze, orange orchid flower grown in 4 inch pot.................................. 2.75

Beacon, Dwarf Green, red orchid flower, grown in 4 in. pot ......................................... 3.00 Humbert, Dwarf bronze orange scarlet flower grown in 4 ill. pot ..................................... er grown in 4 in. pot. Each, 35c................ Queen Helen, Medium size green yellow flower grown in 4 in. pot. Each, $25 \mathrm{c}$................ 3.00 Mnsafolia. Tall, green foliage, small red flower grown in 4 inch pot, foliage effect

Gladiolus. Planted every two weeks from time soil can be cultivated until July; will give a lot of bloom from June until cut down by frost. Plant 6 inches apart in rows. We quote only first size, first quality bulbs.

America Soft lavender pink, very light, almost a immense flowers. first size bulb. 5c each; doz., 4fe; per $100, \$ 3.00$.

Empress of India Dark, blackish-red, the darkest and extremely rich, first size bulb. Each, 10c: doz. \$1.00, ner $100 \$ 6.50$.

Mrs. Frances King Effective Flower spike with a tinually opening. Flower $41 / 2$ inches, a brilliant vernilion scarlet. Each, 5c: dez., 50c; per 100, \$3.00.

Panama A new seedling of America, which is a flowers much deeper pink. Spike very long with $8 \mathrm{r}$ : 2 for 15e; doz.. 75e; per 1.00, $\$ 6.00$.

Mrs. Frank Pendleton In addition, the size of any other. One of the most exquisitely colored. The color is a delicately flushed salmon pink, first size bulb. Earh. 10c; doz., \$1.00; per $100 \$ \% .00$.

Princeps The flowers are 5 to 6 inches broad. The Princeps color is brilliant scarlet crimson, carrying mostly three broad, white blotches on the lower petals. first size bulb. Each, 10c; per doz. $\$ 1.00$.

Niagara In color the flowers are a delightful cream ments blending to a canary yellow. The throat is splashed with carmine, first size bulb. Wach, 8c; doz. $\$ 1.00$; $\$ 6.50$ ner 100 .

Le Marechal Foch A Holland introduction. Very " delicate pink. A seedling of parent. A heavy propagator and an early forcer. First size bulbs 10c each; $\$ 1.00$ dozen.

Herada New and elegant. The blooms, which are ing and clear. Tall, straight spikes. First size bulbs 10 each: $\$ 1.00$ per dozen.

Mrs. Watt Glowing American Beauty shade of winered. Well open flowers on an erect spike. First size bulbs 10e each; $\$ 1.00$ per dozen.

Schwaben (See also "Morning Glory.") Clear canthe throat. A strong grower and a popular Glad. First size bulbs 10c each; 75c per dozen.

IMPORTED BULBS MIXED. First size, first quality bulbs, beautiful blend of colors. Doz. $40 \mathrm{c} ; \$ 2.75$ per 100 .

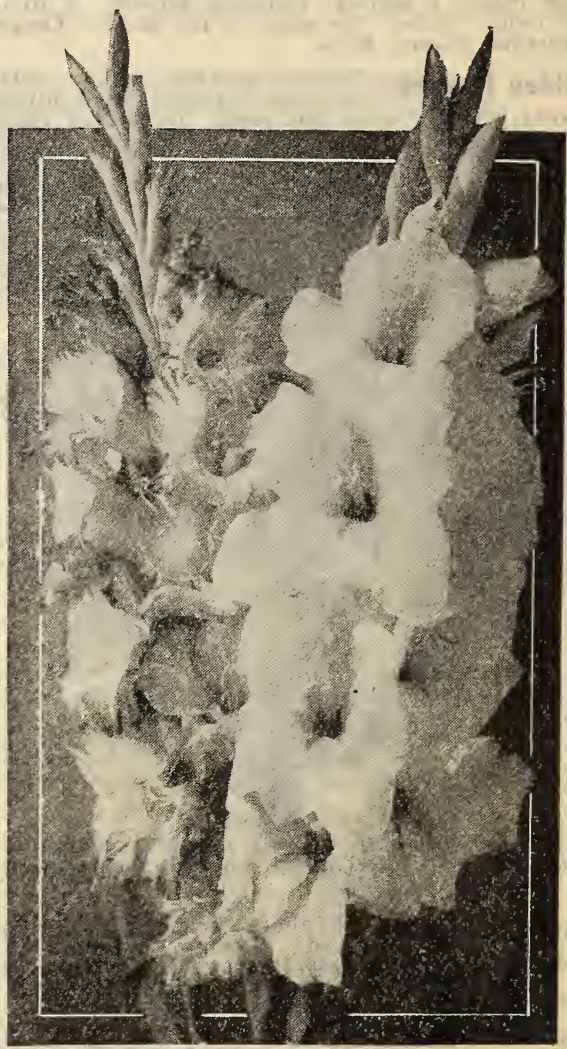

NATIVE MIXTURES. All kinds home-raised bulbs. Doz. 25e; $\$ 2.00$ per 100 . 


\section{HERBACEOUS FLOWERING PLANTS, ROOTS AND BULBS}

\section{Lilies}

Auratum Lilium (Gold Banded. Lily). The grandest of all hardy Lilies: flowers white, spotted with maroon, having a bright yellow band through each petal. Each, 25c: doz., \$2.50.

Auratum Rubrum (Lily). Enormous flowers, inches across: pure white, beautifully spotted and with a deep crinson stripe. Each 25c; doz., $\$ 2.50$.

Lily Album One of the most popular of all each, 25c: per doz., \$2.50.

Lily Tigrinum (Tiger Lily). Single and hardy Lily Tigrinum native Lily, orange spotted with purple. Price each. 15c; per doz. \$1.50.

Lily Tigrinum (Double Tiger Lily). Well Lily Tigrinum known variety of rich orange blossom. Price each, 25c: per doz., \$2.50. Lilium Candidum (Madonna or Annunciation Lilium Candidum Lily). This is one of the oldest, loveliest and best known Lilies. The flowers are snow white, with the most delightful fragrance. Each, 25c; doz., \$2.50.

Lily Funkia Sieboldiana A bell-shaped lilac Lily Funkia Sieboldiana colored flower that blowms in great profusion. Price each 15c; six for $75 \mathrm{c}$; per doz. $\$ 1.25$.

Lily of the Valley The most charming of the each, 5c; doz., 50c; large clumps, each, 25c.

\section{Hardy}

Bleeding Heart (DICENTRA Eximia) Evord'ep rose, heart-shaped, tapering to a neck, which is longer and narrower than in Formosa, the tips of the outer petals much longer. Fern leaved, Price per clump, each, 75c.

Bleeding Heart An old-fashioned favorite, forcing as for planting the open border. Price: Clumps. each, 50c.

Campanula (Bell Flower). Bell-shaped flowCampanula ers, well known and most ersily grown. Price: Field Clumps, each, 25c; doz., \$2.75. Columbine (Rocky Mountain). (The Colorado lavender and white; each. root forms a large clump. Each 250; doz., \$2.50; Potted Plants, doz., \$2.00.

Coreopsis Grandiflora A showy border plant with large, handthrough the season. Each. Delphinium (Hardy Larkspur). Few plants are so handsome in doz., \$2.75.

\section{Chrysanthemums}

HARDY OLTUOOR VARIETY. These are gaining in popularity in recent vears for the reason that they establish themselves to withstand the severity of winter.

PINK (Old Pink) Hardy, large flowering, September and October bloomers. Each 25c; \$2.75 per dozen.

WHITE (Snow Clad) Hardy. large flowering, September and October bloomers. Each 25c: \$2.75 per, dozen.

YELLOW (Canariense) Hardy, large flowering, September and October bloomers. Each 25c: \$2.75 per dozen.

CRIMSON (Autumn Glow) Harly, large flowering, September and October bloomers. Each 25c; \$2.75 per dozen.

Half dozen, either variety, \$1.40.

Golden Glow (Chrysanthemum). A large, very showy plant, attaining a height of six feet, producing bundreds of flowers reselnbling yellow Chrysanthemums. Each, 15c; doz., \$1.50.
Dianthus (Hardy Garden Pinks). Charming nore or less fragrant. Two-year clumps, each,

Digitalis (Foxglore). 3 to 5 feet. Stately old Gaillardia A showy flower, beginning to bloom easoll. tive flowers in summer decorarange from bright red to deep last for many years. Mixed colors, 10c each

lio dozen.

Richard Wallace. White, with red eye. Price, each. 25c; per doz., \$2.50. each, 25c: per doz., \$2.75.

to our sentimental affecis still dear to us. A colors, pink, white, crimson or jellow. Shasta Daisies (Alaska). Immense snow white The best daisy in the list. Each 25c;

\section{Not Hardy}

Tuberous-Rooted). For brilliancy of color, duration and profusion of bloom few nlants can compare with the tuberFlar (Caladium Esculentium). Grand tropic-looking plant. In rich soil, if freely watered, they will produce enormous leaves, frequently four feet long, three giant bulbs, 50c each.

of the bulbs all should have. Syn列 Montbretias One of the brightest and most flowers we know of. rom July to October they are one mass of $121 / 2$; 3 for $30 \mathrm{c} ; \$ 1.25$ per dozen.

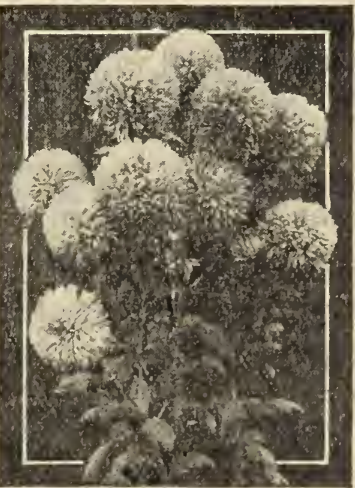

Hardy Chrysanthemums 


\section{Hardy Irises}

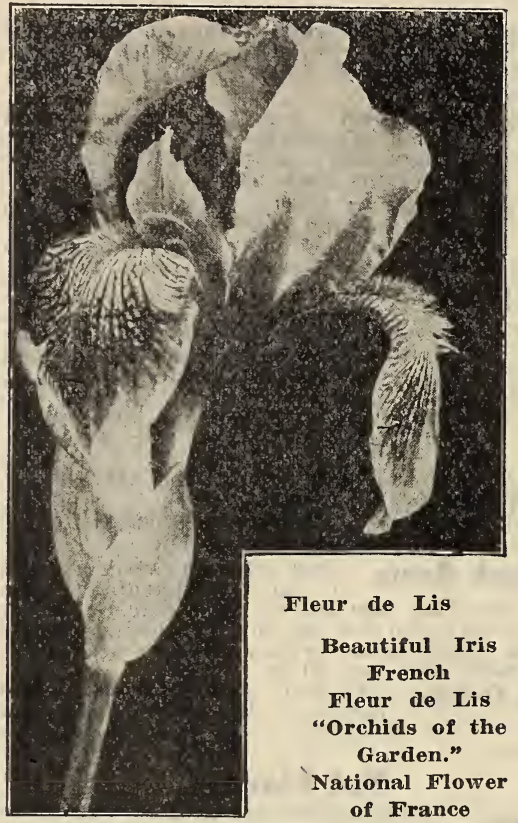

There is a peculiar charm about the Iris that appeals to all lovers of the beautiful in flowers. The blossoms are of rich and varied colors, quaint forms and some varieties are very fragrant.

Culture. A very sunny location suits them best. They can be planted in the spring, but the most favorable time is after blooming, late summer or early autumn.

Mother of Pearl This is reputed to be one of has a strong, vigorous the world's best Irises antful pearl colored flower with a slight tint of lavender in it, which will appeal to all lovers of flowers and is remarkable for its increase of root habit. Price each $\$ 1.50 ; 3$ for $\$ 4.00$.

Black Prince Richest of all the clear dark mense bloom of the Black Prince type. Each, $25 \mathrm{c} ; \mathrm{doz}$. \$2.50.

Juniata Standard petals and falling petals ; Jallat clear blue; large, fragrant flower. The long, drooping foliage. Noted for its fragrance. Each, 35e; 3 for $\$ 1.00$; per idoz., $\$ 3.75$.

Pallida Dalmatica One of the most beautiful Exquisite shade of lavender. Each, 10e; doz., $\$ 1.00$.

Florentine Alba Very large flower, pure white and rare. Each, 10c; doz., 75c; per 100, $\$ 5.00$.

Dwarf Iris (Chamari). Very dwarf. Earliest April bloomer of all, blooming early in work. Each, 5c; doz., 75c; 100, $\$ 4.00$.

Mixed Iris These are made up from choice in brilliant named varieties, fine flowered sorts $\$ 1.75$.

\section{Aquatic Plants \\ HARDY WATER LILIES}

Water Lily (American Lotus) (Nelumbo lutea) Rare and beautiful plant, creamy yellow flowers 10 inches across. Adapted to lakes, ponds, sloughs along rivers; grows in tubs. Price per tubers, 50c each; $\$ 5.00$ per dozen. Seed per oz. $25 \mathrm{c} ; \$ 1.50$ per $1 \mathrm{~b}$.

Water Lily, White (Castalia odorata). A sweet scented white flowering water lily. Price per tubers, 25c each; per dozen, \$2.50.

Water Lily, Yellow, Spatterdock, (Nupliar advena). Tubers or plants, 35e each; $\$ 3.00$ per doz.

Wapato Lily (Sagittaria latifolia) attractive for water fowl, ornamental, arrow shaped leaves, white and yellow flowers, grows rapidly. Price per tuber, 25c each; per dozen \$1.50.

Water Hyacinths (Pondeteria). Very interesting and beautiful, floats on the surface of the water and produces fine spikes of rosy lilac orchid-like flowers.

Wild Rice Giant, attractive clumps and back ground for water gardens, sure growing, large grain variety seed. Per oz. 20c; $1 / 2$ lb. $\$ 1.00 ; \$ 1.50$ per pound.

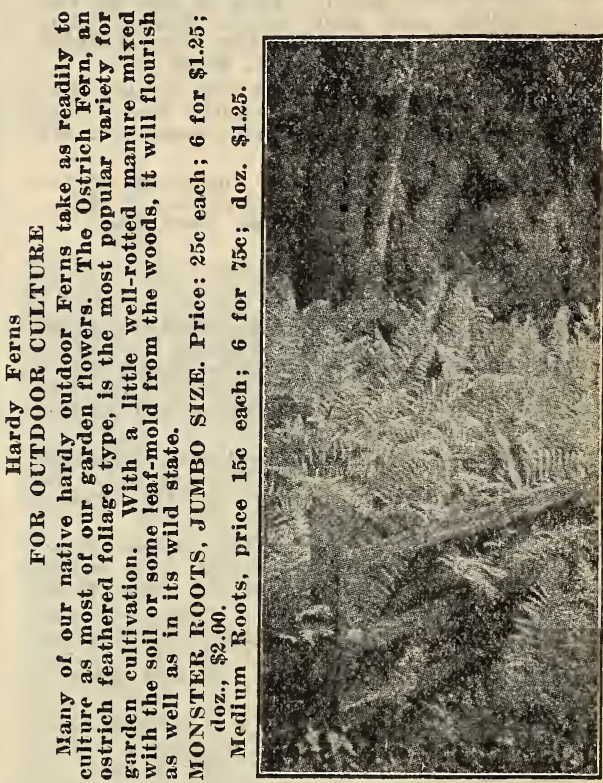

HARDY FERNS in their native heath

\section{Autumn Planting Bulbs}

FOR EARLY SPRING FLOWERS.

SEASON TO PLANT, OCTOBER AND NOVEMBER.

Hyacinth, Tulips, Narcissus, Jonquils, Crocus, and snowdrops, which bloom so early in the spring are for autumn planting only.

Many persons. seeing these beautiful flowers all abloom in early springtime, think they can get some, too, right away, but alas, their surprise and chagrin when informed that to have them in Springtime all abloom the bulbs must be planted the autumn before. We have a catalog of all these Bulbs and Herbaceous Perennial Roots for autumn planting, prices, descriptions, etc., free for the asking.

Remember-We have a complete line of these bulbs in season. September until December. 


\section{Plant Department}

\section{Flowering Plants - Hanging Baskets}

We grow large quantities of all these popular varieties of flowering plants.

Hanging Baskets All flled with beautiful the ceiling on porch or veranda, are charming and attractive to the home. Each, \$2.50 and $\$ 3.00$, according to size and plants used.

Wire Baskets These baskets are first made Wire Baskets of wire for holding plants as a hanging basket proposition, being lined with sheet moss to hold the earth. Price per 12-inch size, 40c; 14-inch size, 50c each. Green Sheet Moss For lining hanging baskets.

FOR BEDDING, WINDOWBOXES AND VASES Aster Plants American type. American purGiant Branching. Potted plants, doz., 50c; mixed in baskets of 1 doz. $40 \mathrm{c}$; in bulk 50 for $\$ 1.25$; per $100 \$ 2.00$.

Coleus Plants For border work. Either Coleus Plants golden, green, red, black and variegated foliage. Price: $21 / 2$ inch pots, doz., 85c. Dusty Miller Plants For foliage only; border Price $21 / 2$ inch pots, doz. 85c; baskets, 12, 50c. Lobelia Plants Easy culture, used in vases Price, 21/2 inch pots, doz., $\$ 1.00$.

Pansy Plants Mixed colors. Michael's Deluxe flowering sort Strain, including large fluted each, 8c; doz. 75c. In baskets, earth, basket of doz. $50 \mathrm{c}$; in bulk 50 for $\$ 1.75$; per $100, \$ 3.00$.

Petunia Plants Single large fringed flowering Price 21/2-inch pots, each, 15c; flowering sorts, each, 25c: doz. \$2.50, Balcony 21/2-in. pots, 75e per doz., in baskets, 50c; in bulk, 50 for $\$ 2.00$; per $100, \$ 3.50$. Verbena Plants Single plants of this pretty space 8 to 10 inches in diameter with neat foliage and scores of fine flowers. Price: All colors, $21 / 2$-inch pots, doz., $75 \mathrm{c}$; growing in basket of carth, basket of doz., soc.

\section{Vegetable Plants}

Cabbage and tomato plants, field grown, revivified frost-proof stock.

We grow large quantities of Vegetable plants and Roots, and can supply all the rarieties listed below in their proper season. Well grown and packed to carry a long distance, they can bo shipped from the beds on a day's notice. All prices subject to season conditions, stocks on hand and change at time of purchase. Write for spring prices-current quotations.

Cabbage Plants Transplanted plants, carly sorts, ready April 15th; late sorts ready May 10th. Doz., 15c; 100, $\$ 1.00$.

Cauliflower Plants Early Snowball and secPlants. Doz., 25c; 100 ond early. Transplanted Celery Plants Ready May 10th. Seedling stock. Transplanted stock, per 100, \$1.50.

Egg Plants In pots or growing in basket of Potted earth only. Basket earth, 50c Pepper Plants Bull Nose and Chinese Giant in Pulk. Dox, 25e; in basket earth, Erowing, doz., 50c; in bulk, 100 , $\$ 1.50$. Sweet Potato Plants Ready about May 5th. Price: 100 plants, 75c; $600, \$ 3.25 ; 1,000, \$ 6.00$ plants. Horseradish Large roots, each, 10c; doz., 75c; Chives Perennial onion. Per clump 25c.

\section{GERANIUMS}

Prices do not include pots.

Geranium Plants The grandest of all bed. ering dark red, pink and white; potted plants only in full bloom. While grown in pots plants are taken out with ball of dirt and wrapped for shipping.

A. Nutt. Best of the dark crimson-scarlet floomer; blooms all summer.

S. A. Nutt, dark red, double flower, 3 in. pots, er doz. \$2.40.

per doz. $\$ 3.00$.

Rickert, light red double flower, 4 in. pots, per z. \$3.00.

Perkins, ideal pink, double flower, 4 in. pots P3.00. Buchner, white, double flower, 4 in. pots, per doz. $\$ 3.00$.

Apple Blossom, single flower, 4 in. pots, per Ivy Geranium, vining variety, 4 in. pots, each,

Madame Solleioi, variegated foliage, 3 in. pots, each $\$ 1.00$.

Salvia Plants Richest scarlet flower; finest of of dazzling red, lasting all summer until prost. Price: 21/2-inch pots, doz., 75c; 4 in. pots, doz., \$2.50; growing in baskets, earth, basket of doz.,

Sprengeru for porch boxes and hanging baskets Price: 3-inch pots, doz., \$2.50; 4-inch, 250 esch. .00.

Vinca Vines For foliage only; variegated and green; hanging baskets and porch boxes. Price: 21/z-inch pots, doz., \$1.50; 3 -inch pots, doz., \$2.25; 4-inch, 25c ch, \$3.00.

Tomato Plants Dwarf Champion (Tree). Ready Grout May 1st. ...Bonny Best and other leading sorts. Per doz. growing in basket earth, basket, $25 \mathrm{c}$; potted, plants, 2-inch pots. Fancy plants, doz., 50e; Transplanted Plants. Loose in bulk. Doz., 15c; per $100, \$ 1.00 ; 1,000, \$ 9.00$.

Seedling Plants. $100,50 \mathrm{c} ; 1,000, \$ 4.50$.

Asparagus Roots Crowns should be set earls in spring or late in eall. old roots Palmetto. 2-year Proof, per doz. 25c; per 100, $\$ 1.50$.

Rhubarb or Pie Plant (Michael's New Seedless). This new va until the seeding fatured from root division it seldom throws seed stock. It is pink meated, very juicy, brittle, tender and a powerful grower. Root division of 2 to 3 ejes. Each, 150; per dozen, \$1.50.

RHUBARB-Common variety, 2-year No. 1 roots. Each, 10c; per dozen, 75c. 


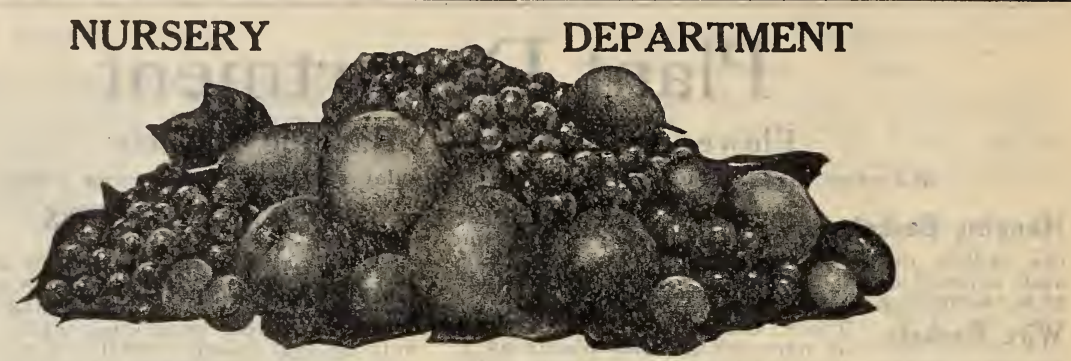

IMPortant to Prospective Customers of Roots, Bulbs, Plants, Nursery Stock, Etc.

We handle only such kinds and varieties of trees, shrubs and plants as grow here and stand this climate. Stock strong, true to name, dug when wanted and roots carefully packed in wet moss for shipping. All prices subject to market change.

OUR NURSERY DEPARTMENT is in the basement of our concrete seed store building at 316 Pearl Street, well lighted with electricity as a salesroom and an ideal place for keeping nursery stock, bulbs and roots just as fresh and nice for two or three weeks as though they were dug out of the ground and where too, there can possibly be no effect from weather changes that are often severe, damaging shrubbery that is not well protected after it is dug in the spring time and before it is planted.

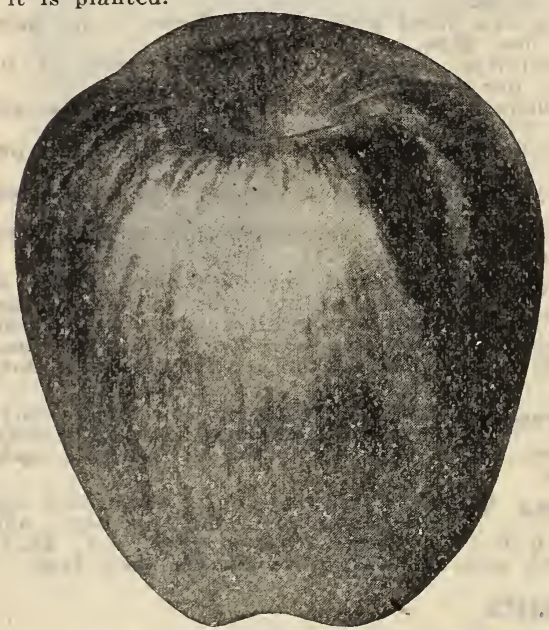

THE “TRUE DELICIOUS" APPLE

The Delicious originated 20 years ago at Peru, Madison Co., Iowa. The original tree still flourishes, bearing an annual crops of beautiful fruit. Fruit is large, with the surface almost covered with a most beautiful brilliant dark red, blending to golden yellow at the blossom end. In quality it is unsurpassed, flavor slightly acid, delightfully fragrant, flesh fine-grained, crisp, juicy, melting and delicious. Good keeper, coming out of storage in March or April in perfect condition. 5 to $6 \mathrm{ft}$. select trees, only specimen stock. 75e each; 2 for $\$ 1.25 ; 5$ for $\$ 3.00$.

Ben Davis A tree highly esteemed in the West. Fruit conically shaped, striped and of fair quality. Very productive. 5 to $6 \mathrm{ft}$. trees, $50 \mathrm{c}$ each; 5 for $\$ 2.00$.

McIntosh Red Canadian (Ontario) origin; exMcintosh Red tremely hardy and does well eren in the exposed cold regions of Montana and Wyoming and very popular in the Northeastern states. It bears a big red apple above medium; a beautiful crimson; flesh snow white; slightly acid and a wonderful keeper. It is growing more popular wherever it is known. 5 to 6 ft. trees, 75e each; 4 for $\$ 2.50$.

\section{Summer Apples} Red June (Wilson)-A glorious deep red early sumng. Tree is hardy and has stood 40 degrees below zero without injury. 5 to $6 \mathrm{ft}$. size, $75 \mathrm{c}$ each. Yellow Transparent One of the earliest apples. Tree year old trees frequently produce fruit. Medium large, mooth transparent. Skin is pale yellow when ripe. Flesh white, and splendid quality. Does well most anywhere. Is perfectly hardy. 5 to $6 \mathrm{ft}$. $60 \mathrm{c}$ each.

Duchess of Oldenburg From Russia, extremely hardy, tripes. Somewhat medium size, yellow with red these trees should be in every orchard. Will not keep ong when fully ripe. 5 to 6 foot trees, 60e each.

\section{Fall and Winter Apples}

Wealthy A seedling originated in Minnesota; very large, dark crimson; flesh crisp sub-acid, white tinged with red; good quality. Tree a fine, upright grower, oth in the nursery and orchard, Season, October o December. 5 to $6 \mathrm{ft}$. trees, $75 \mathrm{c}$ each; 3 for $\$ 1.75 ; 6$ for \$3.25. Budded stock specimen trees, 5 to $6 \mathrm{ft}$. $75 \mathrm{c}$ ach.

Northwestern Greening Tree of Wisconsin good quality. It is claimed to greenish-yellow June. 5 to 6 ft. trees, $60 \mathrm{c}$ each.

Malinda A very hardy yellow winter apple; good keeper, skin rich yellow with pinkish blush on the cheek of the apple. Rich flavored, juicy, with a mild sub-acid taste. Root grafted stock, 5 to $6 \mathrm{ft}$. trees, 75c each; 4 for $\$ 2.50$. lowa Blush Originated in Iowa. Tree very fruitful, strong grower. Fruit rather conical, surface smooth, yellow, with bright mottled red blush, white flesh, juicy and rather sub-acid. November to January is the season it is good to eat. 5 to 6 ft. trees, 75e each; 2 for $\$ 1.25$

Jonathan A brilliant dark red apple of excellent quality. Tender, spicy, rich and juicy. It is one of the most popular varieties for commercial planting. October to March. 5 to $6 \mathrm{ft}$. trees. Specimen stock. 75c each; 6 for $\$ 3 . \tilde{50}$.

Winesap old favorite, vigorous grower, and er. 5 to $6 \mathrm{ft}$. trees, 60c each; 4 for $\$ 2.00$. 


\section{CHERRIES}

The Cherry is the most valuable of all fruit trees for the Northwest; perfectly hardy, grows and thrires on any of our soil. An annual bearer; ornamental as well as valuable.

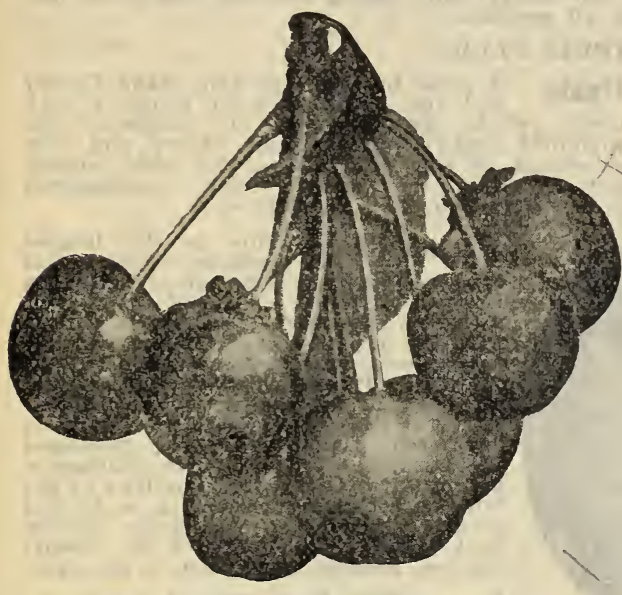

Early Richmond

Early Richmond An early red, acid cberry, Tree a free grower, hardy, healthy and very productive. It is the leading market variety for this section. Ripens in June. See picture in colors outside back cover. ซoc each.

Large Montmorency Large, red, acid cherry; Richmond and about ten dar's later. A superior sort for home use. ize each.

English Morello Trees very hardy and great the late varieties. Fruit large, round; skin lark red, becoming nearly black when fully ripe; pleasant sub-acid flaror when fully ripe. Seasou, July and August. 75e each.
Wragg Originated in Iowa. Large, dark red fruit, dwarfish growth. Very hardy. mercial variety. \%c each.

\section{SWEET CHERRIES}

Terry Cherry A hardy production in sweet r. cherries introduced by the late known Iowa nurseryman. Not wly equal to the California Black in its fruit but a sweet cherry that is hardier and more lasting and a good fruiter. Very productive, rapid grower, earlier in season than the Richmond, bearing a dark red sweet delicious cherry. Every lover of cherries should have at least one of these trees growing on their place. Price: each, $\$ 1.00 ; 2$ for $\$ 1.75$.

Black Tartarian Very large, fruit of purplish black color, flesh is mild and sweet. Tree is vigorous, upright yrower, and immense bearer. A sweet cherry of the Ox-heart type. Each, \$1.00.

Golden Glass A new Sweet Cherry immense size, Oxheart type, yellow color almost transparent. Hardy as the Richmond and ripens a few days later. Each, $\$ 1.00$.

PRICES: Cherry, standard varieties, very select, picked trees, 5 to 6 feet, each $\$ 1.00$.

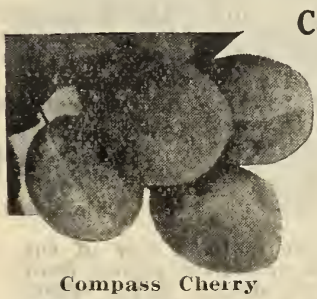

Compass Cherry Plum Absolutely hard $y$ everywhere. Originat ed in Minuesota. A cross between $t \mathrm{~h}$ e Sand Cherry, Morello Cherry, and the Miner Plum. Produces fruit the next year after setting out. Each \%õ.

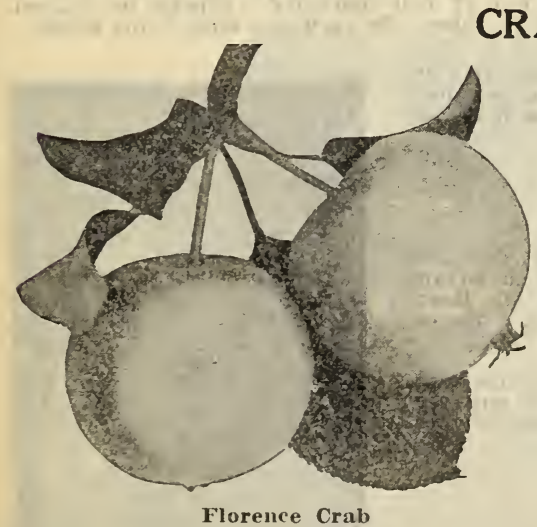

The Florence Crab The most raluable crab erer fruited here. Annnal bearers, usually fruiting the second season after vlanting. Early, large. beautiful, excellent, roungest bearer, most prolific of all. Hardiest and most ornamental fruit tree we grow. Exempt from blight. Each, $75 \mathrm{c} ; 2$ for $\$ 1.25 ; 3$ for $\$ 1,75$
Whitney No. 20 (Hybrid Crab). Fruit very ple striped red with yellow flesh; rather juicy and grained. Healthy and vigorous tree, upright, rather conical in growth and a beautiful tree. 35e each; 2 for $\$ 1.25 ; 3$ for $\$ 1.75$.

Red Siberian About an inch in diameter, grown in clusters; bears young and abundantly. August to September. \%5c each.

\section{Dwarf Apples}

The Dwarfed Apple trees we offer are any of the standard varieties, adaptable to this work, budded on a American Ducine (Paradise) Apple stock, which has the effect to dwarf the growth of the standard varieties when budded on this ancient stock. This habit of growth makes it essentially a city tree for the reason that Dwarf trees bear when very young, beginning to bear the second year they are out. Varieties we offer: Wealthy and Delicious, 3 to $4 \mathrm{ft}$. trees, $\$ 1.00$ each. 


\section{PLUMS}

\section{A LIST OF THOROUGHLY TESTED AMERICAN VARIETIES}

The Plum tree attains its greatest perfection on our heavy soils, being entirely free from diszase. Plums are very hardy and grow vigorously in all sections.

\section{PROF. HANSEN'S HYBRID PLUMS} Hanska This is a cross between a wild north. Opata A cross between the Dak. Sand Cherry The flat shape of this plum and its peculiar red large hybrid by Burbank. It possesses the color with its heavy blue bloom distinguishes sprightly acidity of the. Sand Cherry and rich it from all other hardy plums grown in the sweetness of the Gold Plum, the male parent. Northwest. Tree a very strong grower and very Season extremely early. Dark purplish-red hardy. An early and profuse bearer; quality fruit. Per each, 75c; 3 for $\$ 2.00$.

good. Per each, 75c; 3 for $\$ 2.00$.
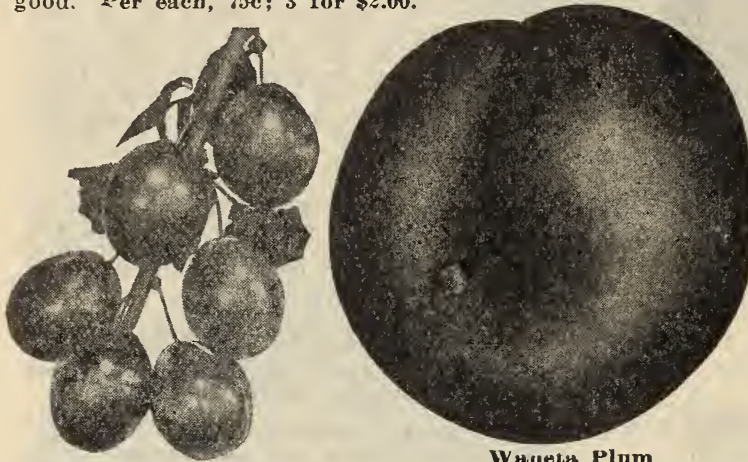

Waneta Plum This is the largest ten thousand ruiting variety out of Hybrid varieties. Size of fruit, two inches in diameter. The tree is a cross with the Japanese Apple Plum and our native Iowa variety (Prunus Americana) the Terry Plum, which bears the largest fruit of all the native or Chickasaw varieties. Color of the fruit is dark red, flavor delicious; possesses the hardiness of the native Chickasaw parent with the fruiting qualities of the famous Japanese variety; an early and profuse bearer. See picture outside back cover. Price: 5 to $6 \mathrm{ft}$, 2-yearold top growth, $\$ 1.00$ each; 3 for $\$ 2.75$.

Sapa This is a cross between the Western Sand Cherry and darl purple-fleshed Japanese variety, dark purple skin and rich dark purple flesh Plum called Sultan. The fruit has the glossy skin and rich dark purpre rea mesz of its Japanese sire. The Sapa attracted great attention as a new departure in stone fruits for the prairies of the Northwest. Begins bearing second year out and yields so abundantly as to cause the whole tree to droop prostrate to the ground with fruit. Each, 75c; 3 for \$2.00.

\section{SPECIAL PRICES ON ANY OTHER VARIETIES IN QUANTITY}

\section{Native Plums}

\section{Chickasaw Varieties}

Terry Plum The largest frult of any of the 2 inches in Chickasaw or Native plums, fruit 2 inches in diameter. Tree strong, large, vigorous grower and perfectly hardy. Fruit bright, attractive color, and very firm. Price: 5 to 6 ft. trees, 50c each; 3 for $\$ 1.40$.
Burwood Tree is extremely hardy. It comes into bearing young and bears so is an a retard the growth of the tree. It an anual bearer. Fruit good size and quality. Color red at full maturity. Ripens in August. 5 to $6 \mathrm{ft}$. select, $75 \mathrm{c}$ each per tree; 3 for $\$ 2.00$.
Wild Goose (Improved). Tree a very strong, vigorous grower. red and of good quality. A valuable variety to raise. 5 to 6 ft. $75 c$ per tree; 3 for $\$ 1.75$.

\section{PEARS}

Flemish Beauty The hardiest of all the rich, juicy, delicious pears; hardy and productive and live to advantage the farthest north of any of the pears we know of. Bearing here in this city. Handsome and surpassing in quality. 75c ea

Keiffer This is the most popular pear grown; fruit of fine size, rich color and good quality; tree very vigorous and seldom blights: should be picked at maturity and ripened indoors. October and November. 5 to $6 \mathrm{ft}$. trees $75 \mathrm{c}$ each.

\section{Mulberry}

Russian Mulberry or Bird Mulberry. Introduced to this country its by Russian Mennonites and on account of The fruit is much inferior to the native, but is greatly prized by birds, keeping them away from other garden fruit.

For hedge size, see page 46, Trees 5 to 6 foet, 50e each; 8 to 10 foet, 75c each,

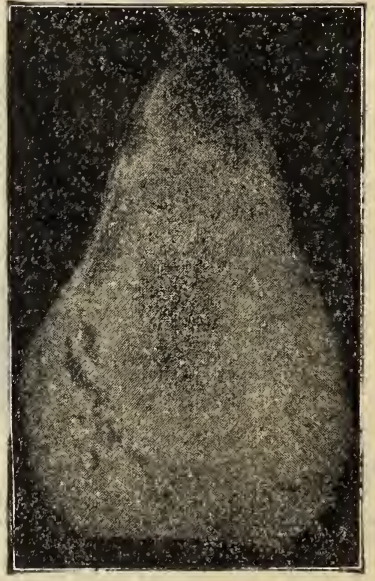

Flemish Beauty 


\section{Currants}

Hardy, easily cultivated, standing neglect well, indispensable for table use, jellies, etc. Set four feet apart in rich ground. If the currant worm appears, dust with hellebore.

Diploma This is the largest known variety of Red Currants in existence. Won the Pan-American Medal at the Buffalo Exhibition on account of its size and excellence. It is a strong, upright grower, prolific bearer, beautiful red berries of finest quality. 35c each; $1 / 2$ dozen, $\$ 1.75 ;$ dozen, $\$ 3.00$.

Perfection A new Currant, more popular now Pay's. A heavy berry and very attractive fruit of an unusual bright red color. Size and bunch uniform. 35c each; 1/2 dozen, $\$ 2.00 ; 1$ dozen, $\$ 3.00$.

Fay's Prolific It has giren general satisfacrecl, tion; fruit very large, bright red, and of excellent flavor, less acid than Cherpicking, and is enormously productive.

White Grape Currant Berries large, very proWhite Grape Currant ductive. Much sweeter and better quality than the red varieties, excellent for table use.

Prices above: For 2-year, No. 1 standard varieties, $25 \mathrm{c}$ each; $1 / 2$ dozen $\$ 1.25$; dozen $\$ 2.25$. Special prices per 100 .

Black Champion The leading well-tested black cellent quality, strong grower. Kinds not priced.

\section{Gooseberries}

Should be planted in good, rich soil and well manured once a year. Even more rugged and easier to grow than Currants. Do not let bushes grow too thick; the fruit will be larger and more plentiful.

Downing Large; light green; soft, tender, good Dlaror; extremely vigorous, hardy and prolific. Per each, 25c; doz. \$2.50.

Houghton Most productive. Best payer of all. Fruit excellent quality. 2-year, each, 20c; $1 / 2$ doz. $\$ 1.00$; per doz., $\$ 1.75$; per $50 \$ 5.00$.

\section{Buffalo Berries}

Buffalo Berry Silver gray foliage quite like the Russian Olive in appearance. A native of the Missouri River country, hardy and most prolific bearer, fruit resembles the currant, a beautiful red color, ripens in July. 2 to 3 feet, $25 \mathrm{c}$ each; 5 to 6 feet. $\%$ ce each.

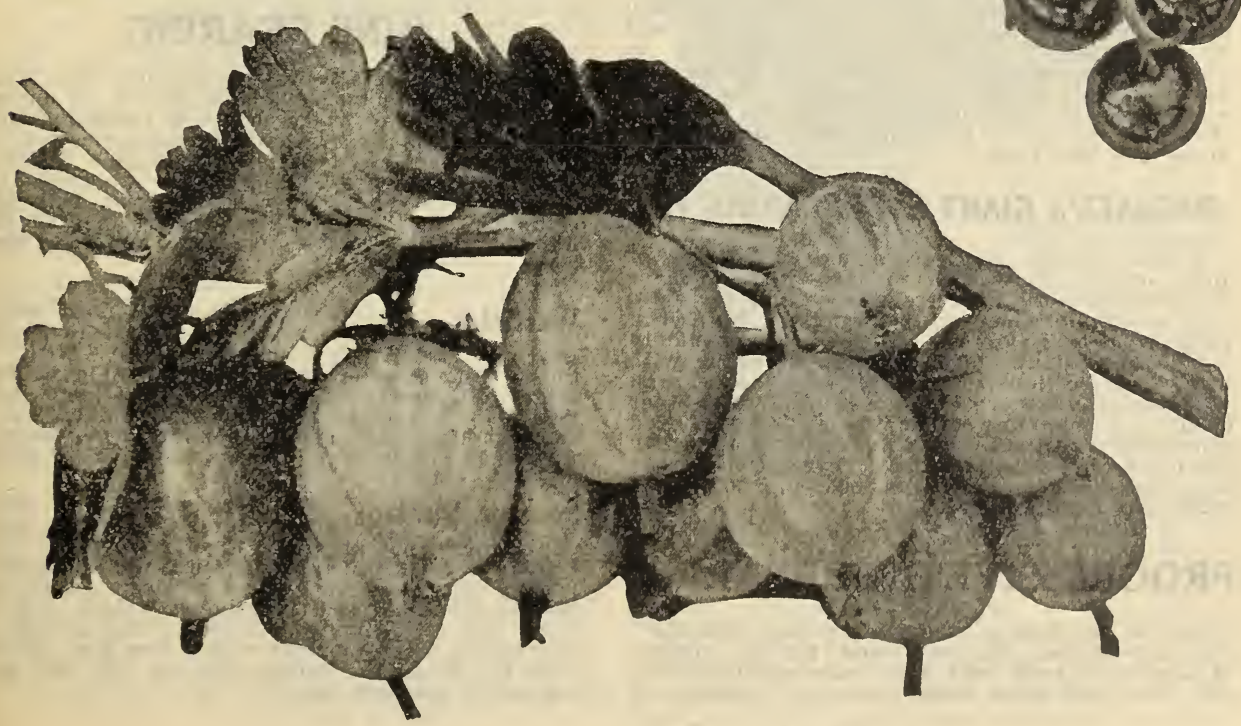




\section{STRAWBERRY PLANTS}

Strawberries will succeed in any soil that is thoronghly prepared to a good depth. For field cultivation set in rows 3 to $3 \frac{1}{2}$ feet apart, 15 to 18 inches each way. To produce fine, large fruit, keep in hills, pinching runners off as soon as they appear. All are put up in bunches, 25 plants to bunclies.

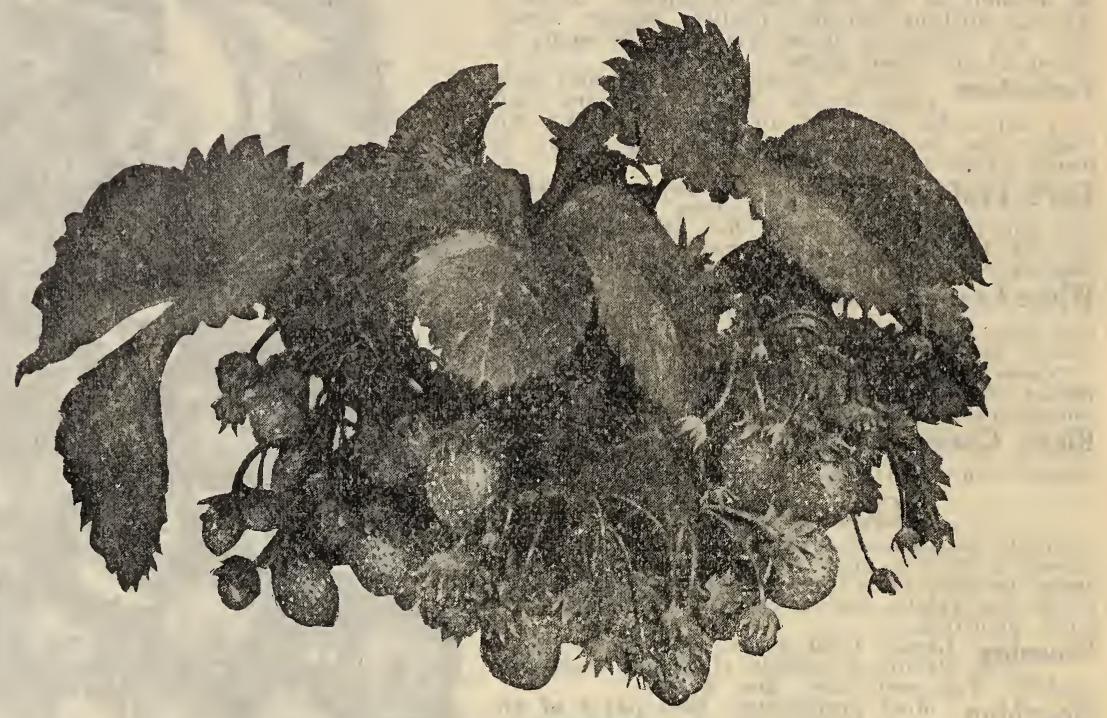

Everbearing in Fruiting

\section{MASTODON EVERBEARING}

This is the largest and greatest achievement in the production of new Everbearing varieties of Strawberries. It is difficult to describe it and do justice. In size it fully out-classes all the other kinds of Everbearing. Three berries will fill an ordinary glass tumbler. Mastodon is sweeter than the other varieties, also firmer. Its unusual size is carried throughout the entire season, the last pickings being fully as large as those of the first. Price per doz. 75 ; per 25, $\$ 1.25$; per 100, \$4.00.

\section{MICHAEL'S GIANT EVERBEARING (B)}

A new variety of Everbearing Strawberry of Iowa origin. Berries very large with a flavor and fragrance different from any other sort; are even palatable when yet partly green but when fully ripe they are very luscious and simply wonderful. Plants are strong growers with heavy root section to the depth of 15 inches and will withstand more drought and dry weather conditions than any other variety known. Ten rods square beds have been known to yield nearly 200 pints to the bed the same year they were set out. Price per dozen plants, 50c; per 50 plants, $\$ 1.50$; per 100 plants, $\$ 2.50$.

\section{PROGRESSIVE EVERBEARING}

One of the first of the Everbearing Strawberries introduced. Vigorous and healthy plants. It begins to bear with the June bearing varieties and will bear with favorable weather off and on all summer winding up with a good crop of berries in the fall. To insure good crop in the fall, cultivate during the summer and keep the runners off. Price in bunches of 25, 50c per bunch; per $100, \$ 1.50$; per $1000, \$ 10.00$.

\section{JUNE BEARING}

Cooper This is a berry of enormous size, beautiful color, delicious, and of an unusually sweet flavor which makes a leading standard variety of June bearing Strawberries that is now growing anywhere. Nine berries make a layer in full quart boxes. Plants are very productive with every berry ripening in full and complete and last pickings are as real as the first. Price per 25, 50c; per 100, $\$ 1.50$; per 1000 , $\$ 8.00$.

Warfield (P). Early. One of the most popular varieties of strawherries grown; large, top shaped berry, with a glossy red exterior that does not fade or become dull after picking; exceedingly juicy, just tart enough to make it delicious. Plant with two rows of Warfields, one of Dunlaps. Per bunch, (25) $\$ 1.00$ per 100 ; per $500, \$ 4.50$; per 1000 , $\$ 7.50$.

Senator Dunlap (B). Perfect blossom. Medvarieties known to the strawberry world. Dunlap is a large, handsome fruit, rich, dark red, with a glossy finish, shaded to deep scarlet on the under side, and prominent, bright yellow seeds that look like gold bronze. The foliage is tall, bright green, upright with a long leaf. Plant with Warfield. Per bunch (25) 75e per 100; per $500, \$ 3.75$; per 1000 , $\$ 6.00$. 


\section{GRAPE VINES}

One of the best, healthiest and longest cultírated fruits we have. Easy to grow in most any kind of soil that is not too wet, even a stony hill brings good results. Yet they are great feeders and pays to manure them well when planting, rich, well-rotted manure mixed in the soil.

INSTRUCTION-Grape vines should be planted so that the first bud next to the stem will come on a level with the surface of the ground. Grape vines have two layers of ruots, from 6 to 8 inches apart, and in planting spread the lower layer of roots in their natiral position; fill in the earth and press down in the soil firmly, then spread the second layer of roots and fill in the balance of the hole- After planting trim the vines back to two buds.

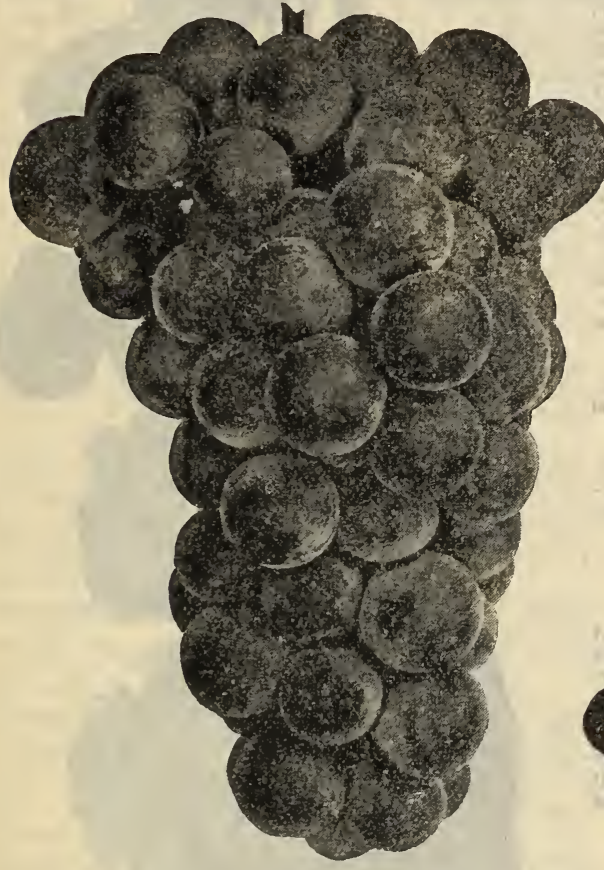

Concord Grape

Concord The most popular grape in America. belries large, covered with shouldered, compact; vo. 1 2-year-roots, with a rich, dark doz., 25 for $\$ 3.50 ; 50$ for $\$ 7.50 ; 100$ for $\$ 12.50$. Special prices in large quantities.

Niagara White. This is the most valuable large and handsome, compactly filled with large berries. When fully ripe, they are a pale yellow with a thin white bloom. Price: 2-year-old roots, $25 \mathrm{c}$ each: \$2.50 per doz.; \$15.00 per 100 .

Campbell's Early Black. A new variety of very hardy, foliage perfectly healthy, very early and abundant bearer. The berries are large, nearly round; dark blue. Price: No. 1 2-yearold star stock, each 30c; doz. \$3.00.

Caco A novelty in grapes. New rariety and come in tonch with. Said to be perfectly hardy and ripens tell diss ahead of the Concord. Good size, compact bunch, large wine red berry, strong rine, healthy and vigorous. Each, 75e; 3 for $\$ 2.00$.

Moore's Early Black with heary blue bloom Bunches of medium size, ra rely quality; desirable for market on account of its earliness. Price: 2-year-old star stock, 25c each; $\$ 2.50$ per doz.; $\$ 18.00$ per 100 .

Agawam Large red grape of rich, sweet, aroAgawam matic flavor. A vigorous, hardy vine. A splendid keeper and very prolific bearer. 25e each; \$2.75 per dozen; $\$ 15.00$ per 100 .

\section{Care and Training of Young Vines}

During the first season after planting, no pruning or training is necessary. The first pruning after planting inay be done at any time dur. ing the winter when the vines are dormant and not frozen The extent of the pruning will de pend on the growth made. If the growth has been small all the canes excent the strongest should be remored, and this one cut back to two eyes. If a strong growth has been made and there is one straight well-ripened cane, all other growth should be removed and this cane cut back to the height at which it is intended to head the rine; this one should be tied securely to the support, as it is to become and remain the trunk or main body of the vine, and should be kept as nearly erect and straight as possible. In summer pruning, the shoots except the main stalk should be removed when young. This con. centrates all the force and growth of the plant into the trunk vine. For more detailed instructions write U. S. Department of Agriculture, Washington, D. C., for Farmers Bulletin 471. "Grape F'ropagation, Pruning and Bearing."
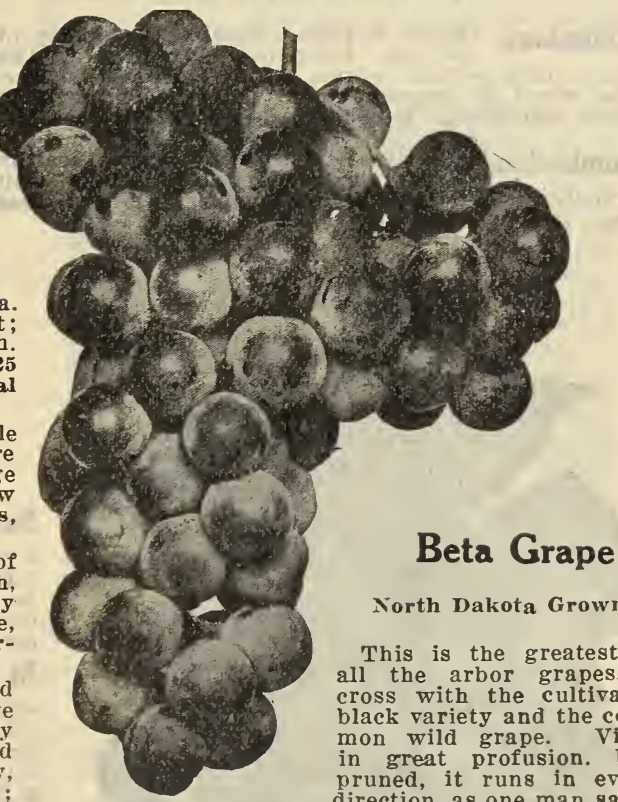

North Dakota Grown

This is the greatest of all the arbor grapes, a cross with the cultivated black variety and the common wild grape. Vines in great profusion. Un. pruned, it runs in every direction, as one man says: the alley fence in its mad flight to cover everything ungightly in sight." Fruit is medium in size; black in color. rather acid in taste, a splendid wine maker. Bears in great abundance, always bearing erery season and is absolutely as hardy as its wild parent. Needs no protection. Price: 2 year-old No. 1, star stock, 35c each; per 6, $\$ 2.00$, per doz. \$3.50. See picture outside back cover. 


\section{BLACKBERRIES}

LaGrange This blackberry is of Russian origin Russia having been brought from arctic fruited by Mr. LaGrange in Vermillion County, Illinois, for the past twelve years and in that time has not received any injury from cold winters. It is the hardiest berry yet produced. The LaGrange is unique in its habit of growth, sending out fruit stems from the ground up, and each fruit stem has ample foliage, each cluster of berries having a leaf. Unlike other varieties, the fruit ripens in the shade and is therefore of superior quality. It begins to ripen early in July and continues for four or five weeks, yielding heavily. In addition to its extreme hardiness of canes, it is a very valuable variety by reason of its large yield, early ripening, long season of fruiting and particularly fine size and superb quality of its fruit. Splendid transplanted plants, strong roots. Price: $25 \mathrm{e}$ each; 6 for $\$ 1.00 ; \$ 1.75$ per dozen.

Snyder One of the best. Berries juicy and sweet. Large and productive. Per doz., 75e; $\$ 4.50$ per 100

Bartel's Dewberry Is hardier than any blackmate-a grand delicious fruit. Each 10c; doz., 75e; per $100, \$ 4.00$.

\section{RASPBERRIES}

Columbian (Royal Purple). Greatest Raspberry of the age. Enormously productive. The color, dark reddish purple fruit. Does not sucker. Has stood 28 degrees below zero without killing; large size berry. Per dozen, \$1.00.

Cumberland Largest of all Black Caps; healthy vigorous grower, stout, stalky, well branched canes that produce immense crops. Per doz., 75̃e; per 100, \$3.50.

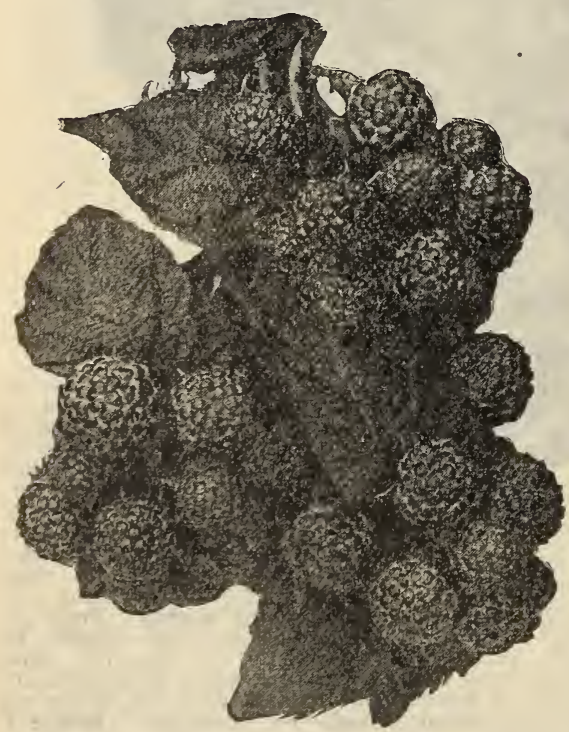

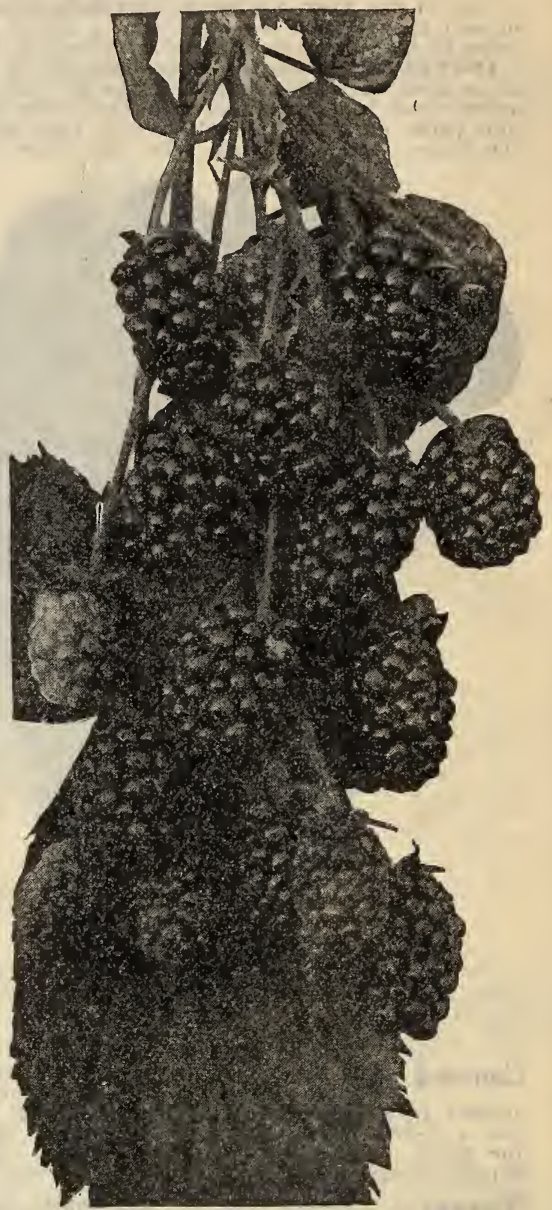

La Grange Blackberry

Sunbeam Originated by Professor Hansen of Brookings Agricultural College. It is ing of Dakota origin it is one of the hardiest red raspberries grown. Quantity of the fruit very fair, medium size and very desirable. Price each, 10c; per doz. 75e: $\$ 5.00$ per 100 .

St. Regis Everbearing Red Raspberries for four what you get when everbearing variety. A brilliant crimson color; the first raspberry to give ripe fruit and bears without intermission until late October. 10e each; 75e per doz. $\$ 3.75$ per 100 .

Herbert In hardiness it easily takes first place, standing a lower temperature than any other kind. The cane is very strong and vigorous slightly prickly, leaves large and healthy. Fruit bright red, somewhat oblong, larger than Cuthbert, flavor very sweet and juicy. Season 5 to 6 days before Cuthbert. Per each, 10c; \$1.00 per doz. $\$ 4.00$ per 100 .

We handle other varieties of both Black Caps and Red Raspberries, standard sorts, which we quote at $75 \mathrm{c}$ per dozen; $\$ 3.50$ per hundred. 


\section{ORNAMENTAL FLOWERING SHRUBS}

Nothing adds more to the beauty of a place than to have the sides and background well filled with groups of shrubbery. Whether you have a lawn of many acres, or an humble dooryard, we recommend this class of plants as indispensable to the real beauty of your home.

\section{Almond Double Flowering Pink. One of the ed down with double pink flowers which attract} attention. 2 to 3 feet, $75 \mathrm{c}$ each.

Almond Double Flowering White.. Like above 3 feet, 75c each.

Crab (Bechtel's Flowering). Makes a medium sized tree; perfectly hardy, succeeds well in all soils. When in bloom appears to be covered with delicate pink, perfectly double small roses of delicious fragrance. Price: 3 to 4 ft., each, $\$ 1.00$.

Butterfly Bush (Veitchiana) This is a very full attractive shrub that matures bush. Blooms beautiful lilac colored flowers. Single plants first year will grow out as many as fifty flowering spikes. Specimen plants, $50 \mathrm{c}$ each; 3 for $\$ 1.00$.

Dogwood (Cornus Siberica). A -very ..hardy, small handsome bush which has a dark red bark, making an effective and showy winter display among other shrubs with handsome white flowers in early summer which are distinctly dainty. Per each, 3 to 4 ft., 50c. Large 5 -yr. old clumps, 4 to $6 \mathrm{ft}$., $\$ 2.50$ each.

Elder, Golden (Sambucus Aurea). A variety Grows to a heith golden yellow foliage. for contrast effect. The berries and is useful Should have full sun to give best effect; can be pruned into a neat, compact little bush. 3 to $4 \mathrm{ft}$., $50 \mathrm{c}$ each.

Forsythia, Suspensa (Golden Bell). These up the lawn with masses of yellow, very early in spring before the leaves appear. 2 to $3 \mathrm{ft}$., $35 \mathrm{c}$ each.

Honeysuckle (Red Tartarian, bush form). upright Grows to a height of 8 feet with green foliage. The flowers are borne freely in May and June, are of a bright pink color. 3 to 4 feet, select, each 35 c $^{2} 3$ for $\$ 1.00$; large clump, 5 year old, $\$ 1.00$.

Hydrangea (Paniculata Grandiflora). Large, fine shrub, growing from 4 to 6 feet high. Flowers white, in large pyramidal panicles, produced in August and September. Each, 2 to feet. $60 \mathrm{c} ; 6$ for $\$ 3.50 ; 3$ to 4 ft. $75 \mathrm{c}$ each; tres form 3 to 4 feet, $\$ 1.50$.

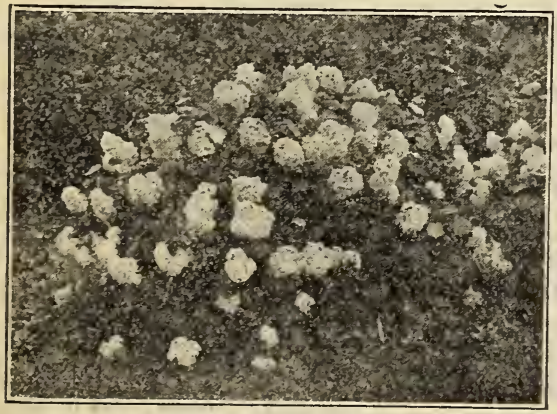

Hydrangea Arborescens

Hydrangea Arborescens Everblooming. Someblooming Snowball. This new American Everbegins blooming in June and continues all serson. Very easy of culture and hardy. Blooms best if flowers are clipped before ripening. 2 to 3 feet, each $60 \mathrm{c} ; 6$ for $\$ 3.50 ; 3$ to 4 ft, 75e each.
High Bush Cranberry This plant has a handsome broad foliage of

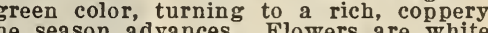
. Flowers are white scarlet and remain on nearly all winter. Per each, 3 to 4 ft., $75 \mathrm{c}$; large clumps, 5 to $6 \mathrm{ft}$, 5 -y ear-old, \$2.50" each.

Prunus Triloba (Double Flowering Plum). A Blooms in May. Flowers double delicate pink which are thickly set on long slender branches. Per each, 3 to $4 \mathrm{ft}$., $\$ 1.50$.

Rhodotyphus (Kerrioides). A distinct decoraare shrub. Foliage very large the followed with black berries that last through the winter. Per each, 2 to 3 feet size 50c. Iarge clumps, 5 to 6 years old, $3 \mathrm{ft}$., $\$ 2.00$ each.

Syringa Philadelphus (Coronarius). (Mock flowers. Price: 3 to $4 \mathrm{ft}$. 50c very fragrant clumps, \$2.50 each.

Syringa Lemoine (Mock Orange). Flowers of double, very fine. The bush is of more dwarfish habit and will not get over four feet high. 2 ft., each, 50c.

Syringa, Golden Leaved A handsome dwarf yellow foliage; keeps its color the entire season; is splendid for grouping with other varieties for pleasing effects. Never over 3 feet high. ft., 750 each.

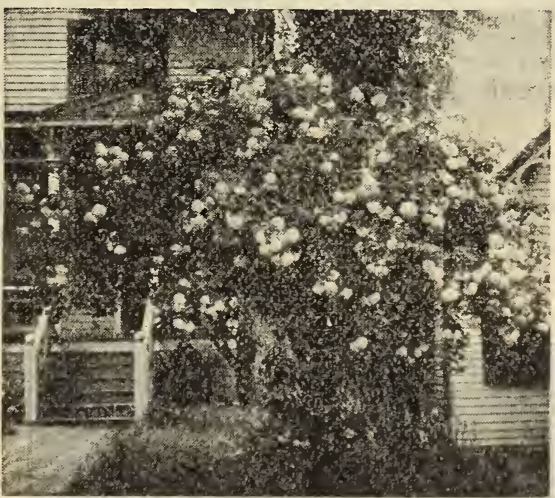

Snowball (Virburnum Opulus Flora Plena). Snowball One of the favorites of old-time gardens. It grows into a magnificent high bush with upright branches and handsome foliage. It forms one of the most impressive sights of early summer, when its pure white four-petaled flowers, borne in showy balls are in bloom. Hawdy overywhere, 3 to 4 feet. 75c each.

Tamarix Africana Has, like all Tamarix, very pretty, feathery leaves of a bright green color, and pink flowers. Generally gets to be 6 to 8 feet high by fall, and makes a fine shrub and with plenty of flowers. Prices: 3 to $4 \mathrm{ft}$., $35 \mathrm{c}$ each.

Weigelia (Eva Rathke). The finest Weigelia ly throughout the summer and autumn; of rich ruby carmine, 2 to 3 foet, $75 \mathrm{c}$ each. 


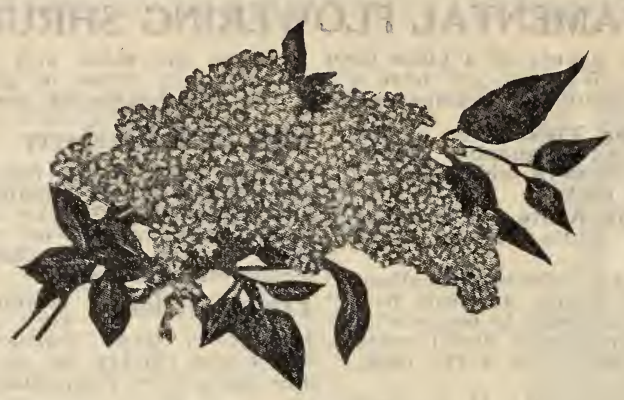

Lilacs

Do you love the lilac? If so we have something rare and bcautiful. Best beloved of the old time flowering shrubs which grows into a high bush with bright green. heart-shaped leaves, whose flowers never fail to charm with their delicate beauty or refresh with their tender fragrance. Can be used to good advantage in making an effective background for smaller shrubs. Hardy ererywhere. New varieties are occasionally produced with a deeper coloring and larger form. Ouı list comprises some of these magnificent sorts.

\section{DOCTOR BROCKENSCHNEIDER LILAC}

This is one of our new creations in new Hybrid Lilacs. The bush grows to a height of 10 fert and has a large. round upright top with a wide spread to it. The leaves are large, broad and oblong and very rich attractive foliage. Flowers grow in clusters and have a rich, dark purplish pink color. Flowers freely each year and being a rather late variety, the flowers do not open up until most of the other varieties have faded. Desirable not only for its fowers but foliage as well. Price per each, $\$ 1.00 ; 3$ for $\$ 2.50$.

Mme. Casmir Perier The finest double white Iime. Casmir Perier lilac yet introduced. The individual flowers as well as the truss are of immense size, deliciously scented; very fragrant. Price: 3 to 4 feet, $\$ 1.00$ each; tree form, 3 to 4 feet, $\$ 1.50$.

Charles 10th A strong, rapid growing variety of budded French Lilac ith large shining leaves. Flowering trusses are large, rather loose with a deep reddish purple flower. Per each, \%5c.

Souvenir de Ludwig Spaeth A choice variety cles of single flowers; dark, purplish blue. Price: 3 to $4 \mathrm{ft}$., each, $\$ 1.00$; treo form, 3 to $4 \mathrm{ft}$., $\$ 1.50$.

Persian Lilac Blooms a good deal more than the common and has smaller roots. Persian white, 3 to 4 ft., $\$ 1.00$; tree form, \$1.25; Persian purple, 3 to 4 ft., 75e.

Lilac Common Purple or White. The oldfashioned lilac, which grows into a very high bush, with bright green, heart shaped leaves. In May covered with light purple flowers. Each, 3 to $4 \mathrm{ft} ., 50 \mathrm{c}$; tree form, $\$ 1.25$.

\section{CUT LEAF LILAC}

This is a Lilac that is entirely different from any of the other varieties on account of the manner of its flowering and its beautiful cut-leaf fern-like foliage. The flowers bloom along the end of the stem in a whirl which is about 14 inches in length. The color is a shade lighter than Persian and blooms in season with that well known variety. Price per each 75c.

\section{Spirea}

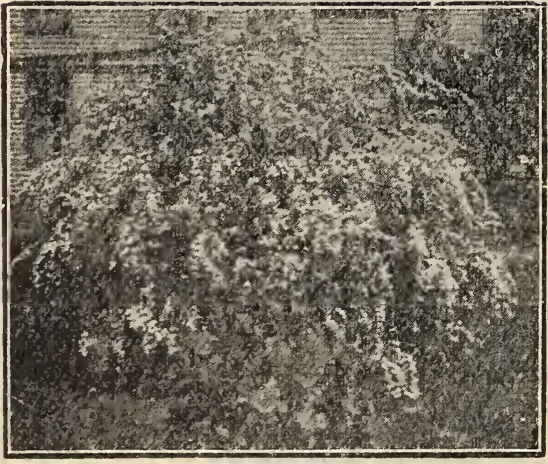

Spirea Van Houttei (Bridal Wreath). We can Spirea Van Houttei say positively this shrub is the most attractive lawn shrub known. Has white flowers, astonishingly profuse in blooming: very fine for cemeteries, 3 to 4 reet, fair clumps, 50c each; 12 for $\$ 4.50$; large clumps, many canes, 4 to 5 feet, each, \$1.00. Pair.\$2.00.' Spirea Aurea A beautiful variety with golden ers in June. Per each, 3 to 4 feet, 40c; large clumps, \$1.50 each.

Spirea (Anthony Waterer. The grand ornamental hedge shrub; grows about $21 / 2$ flowers from June until frost. Price: 18 to 24 inches, each, 50c; 6 for $\$ 2.75$.

Spirea Billardi Rich pink colored flowers in large spikes; blooms nearly al pretty and showy and splendid for cut flowers. Grows 6 feet high. Price: 2 to 3 feet, 35e each; 6 for $\$ 2.00$.

Gloria de Lorraine Splendid large single flowers Gloria large tresses; red in bud lilac when open. Bush dwarf habit not growing over 3 ft. high. Price. \$1.00. each.

Tamarix Africana Has, like all Tamarix, leaves of a bright green color, and pink flowers. Generally gets to be 6 to 8 feet high by fall, and makes a fine shrub and with plenty of flowers. Price: 3 to $4 \mathrm{ft} ., 35 \mathrm{c}$ each. 


\section{HEDGE SHRUBS} Barberry Thunbergi Of dwarf graceful habing to beautiful red early in fall. 15 to 18 inch size, per dozen $\$ 2.00$; per $100, \$ 12.50 ; 21 / 2$ ft. to 3
ft. per each, 35e; dozen $\$ 4.00$; per 100 , $\$ 30.00$; large 5-5ear-old clump, $\$ 1.00$ each.

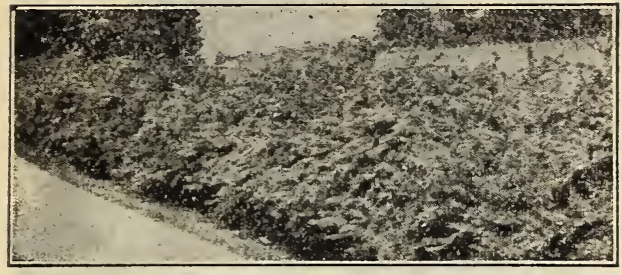

Barberry Hedge, (Thunbergi)

Buckthorn (Rhamnus Catharticus). A dense lieved by masses of attractive white flowers in June and July. Most ornamental of all hedge plants. Makes a good prunable hedge. Price: 18 to 2t-inch size, $\$ 12.50$ per 100.

Caragana (Siberian Pea Tree) Perfectly hardy dwarfish growing tree in this climte and eren in Canada; especially adapted to hedge purposes. Very ornamental, dense foliage, upright limbs and stands shearing well, making a neat and trim hedge. 18 to 24 inch size per $20, \$ \tau .50$; per $100, \$ 13.00$.

Russian Olive Makes a medium sized hedge age growth is silvery white. The most popular hedge plant of the North. Price on application.

Privet, Amoor River Is of vigorous growth, foliage, keeping its color. Price: 18 to 24 inch. 2 to 4 canes, per 100, \$12.50. Ibolium Privet, much like above but richer foliage. 18 to 24 inch, same price.

Spirea Van Houtti (Bridal Wreath). This is nne of the best ornamental know of. Plant same about 15 to 18 inches apart in rows. 18 to 24 inch size, 50 for $\$ 6.00$; per hundred $\$ 10.00$.

\section{CLIMBING VINES}

Moon Flower (Noctiflora): A wonderful Moon Flower climbing vine which grows rapidly to the height of 20 feet in a single season. Flowers open at sundown and bloom all night with a delightful fragrance. Potted plants in full foliage, 4 inch pot size 35 each, 3 for $\$ 1$ See page 19 for seed.

Ampelopsis (Engelmanni). This is one that Ampelopsis clings firmly to the smoothest surface, covering it closely with over-lapping foliage. 2-year, 25e each; 4 for $\$ 1.00$.

Ampelopsis (Veitchii). Boston Iry. It is a object, as it clings perfectly to the smoothest surfaces. Price: 75 each; 3 for $\$ 2.00$.

Dutchman's Pipe Sipho. A plant of climbing wath with magnificent 11ght green foliage, curious, pipe-shaped, yellowish brown flowers. Price:
$\$ 1.00$ each.

\section{Clematis (Now).}

Scented Paniculata. Flowers pure white in large clusters. Bright green foliage and fragrant flowers. Price: 2-year roots, 35 each; 3 for $\$ 100$.

\section{Clematis Jackmani.}

ful, hardy, climbing vine bearing great wreaths and clusters of splendid purple flowers. Price: Potted plants growing condition in foliage, sure to live, each, 75c; 3 for $\$ 2.00$.

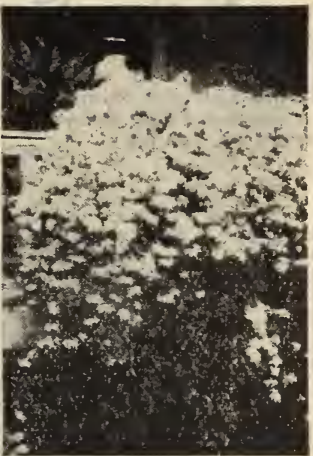

Clematis Paniculata
Cinnamon Vine Well known hardy climber; quick grower, with beautifu] glossy heart-shaped leaves and sweet-scentec flowers. Vines will run 25 to 40 feet in a season Large roots, Jumbo size, each, 15c: dzo. \$1.50. Honeysuckle Scarlet Trumpet. Blossoms freeflowers. $35 \mathrm{c}$ each, 3 for $\$ 1.00$. Honeysuckle Hall's Japan. The finest climbscented; extremely hardy. 50c each.

Madeira Vine One of the best and most popular climbers for foliage effect. Large. bulbs, Jumbo size, each 15c; per doz. $\$ 1.25$. Matrimony Vine (Lycium Vulgare) A very with a half climbing plant ially useful for covering terrace walls when planted on the terrace at the top of the wall It bears small light pink flowers in summer with berries which turn to be a beautiful scarlet in the autumn, producing a very ornamental effect. Price per each, 25e; per doz. \$2.50.

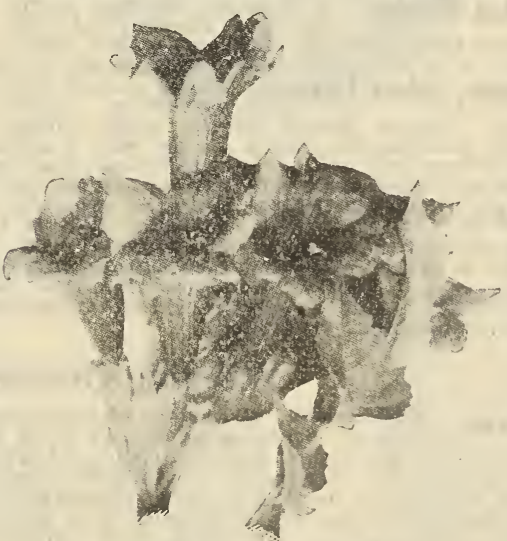

Trumpet Vine Flower

Trumpet Vine Bignonia Radicans. Dark red Very hardy and orange throat, free blooming. ering unsigand rapid grower. Useful for covshowy flowering vlne is desired. Each 35c; 3 for $\$ 1$. Wisteria Purple flowering. Rapld grower. Wisteria Flowers pale blue borne in long pendulous clusters, blooming in May and June. Price: 40c each: 2 for $75 \mathrm{c}$.

Wild Grape Vine Besides being Pruit-rearing hardy. Cultivated vines. Prico: $35 \mathrm{c}$ cach. 


\section{Native Shade Trees}

Below we give a list of shade trees that are bardy and can endure the dry weather of the ivest and the frigid winters of the Northwest.

Special Price on any and all varieties of shade trees in quantity.

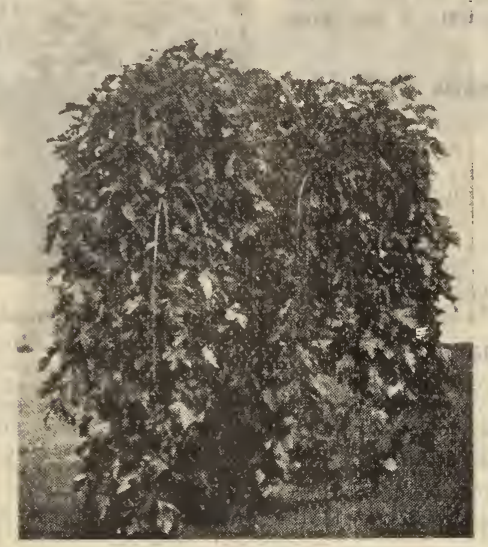

Weeping Mulberry

Poplar, Carolina A very rapid-growing tree but resembling the Cottonwood, but has a larger leaf, thicker and more spreading to $p, 8$ to 10 foot, $75 \mathrm{c}$ each; 3 for $\$ 2.00$; 10 2or $\$ 5.00$. Special price per 100 .

Poplar Bolleana A tall columnar tree of picaspect. A very rapid growing and hardy tree, long lived, leaf bicolored, surface light green under side silvery gray with pleasing most stately tree. 8 to 10 feet, $\$ 2.00$ each; 5 for $\$ 7.50$.

Volga Poplar A Russian variety, hardy and umnar type, like the Lombardy, but more durable. 8 to $10 \mathrm{ft}$. $\$ 1.25$ each; 3 for $\$ 3.00 ; 10$ for $\$ 9$. Poplar, Silver-Leaved Rapid growth and wide form. Leaves glossy silvery green above and white underneath. Very hardy and a splendid. shade tree that will grow anywhere. 8 to $10 \mathrm{ft}$, $\$ 1.25$ ea.; 5 for $\$ 6.00 ; 4$ to $5 \mathrm{ft}$. whips, $\$ 25$ per 100 . Maple, Soft or White A native tree A very med to keep down suckers and avoid forks. 8 to $10 \mathrm{tt}$. $\$ 1.00$ each: $11 / 2$ to 2 inch caliper, $\$ 2.00$ each. Sycamore A lofty, wide-spreading tree, heartshaped leaves. Makes a fine street tree. 8 to $10 \mathrm{ft}$., $\$ 1.25$ each.

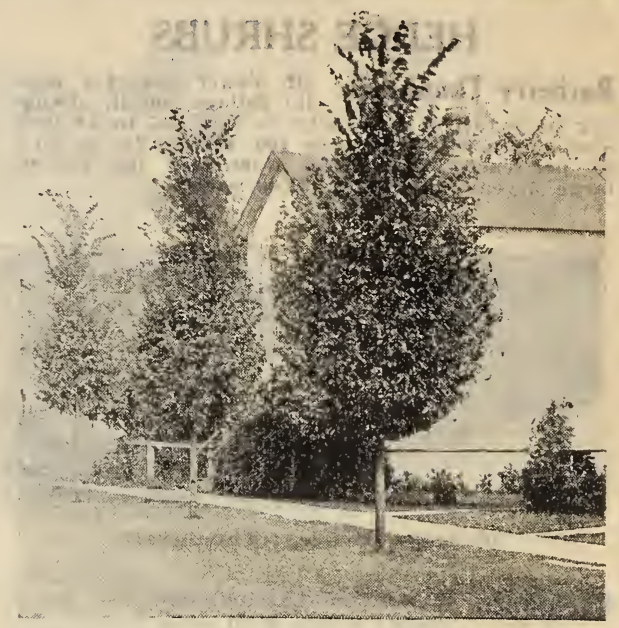

Moline Elm

Elm Moline. A columnar type of our native Elm developed at Moline, Illinois. Tree grows compact with upright limbs like unto Lombardy Poplar. This is a new thing in Elms; hardy and enduring and as rapid a grower as our native variety. 8 to $10 \mathrm{ft}$. size per each $\$ 2.50$. Elm (Vase shaped) Native White American. A native of South Dakota and the entire Northwest. One of the best trees for street use. 8 to 10 feet $\$ 1.50 ; 10$ for $\$ 12.50 ; 11 / 2$ to 2 inch caliper, \$3.00 each; 8 to $10 \mathrm{ft}$. f.o.b. Iowa growing stations, $\$ 1.00$.

Hackberry A very desirable street tree of age. 8 to 10 ft., $\$ 1.50$ each.

Mountain Ash (European). A fine hardy tree; $8 \mathrm{ft} . \$ 1.00$ each. head dense and regular. 6 to

Horse Chestnut (Castenea). White flowering. outline, dense dark A fine large tree of compact ered with white flowers. 5 to 8 ft., $\$ 1.75$ each.

Sugar Maple (Acer Saccharum). A popular American tree of pyramidal form. The foliage is large and handsome and of rich, pleasing green. 8 to $10 \mathrm{ft}$., $\$ 2.00$ each.

Black Walnut This is a common and stateand spreading form and of rapid growth. 6 to 8 ft., $\$ 1.25$ each.

Linden A handsome lawn or shade tree. The blossom is very fragrant and sweet. Price: 8 to $10 \mathrm{ft}$., $\$ 2.00$ each.

\section{Weeping Ornamental Deciduous Trees}

Acasia Moss Acasia. A variety of locust which is most ornamental, grows 5 to $6 \mathrm{ft}$. tall, light green locust leaves, drooping branches. Bears graceful clusters of pea shaped rose colored flowers in June and often throughout the summer. Branches are covered with a moss-like growth similar to the moss rose. Absolutely hardy in this climate and a free bloomer. The tree form is grafted on the stem of the Honey Locust. We offer tree form $5 \mathrm{ft}$. size grafted two-year-old head at $\$ 3.00$ each.

Birch Cut-Lear Weoping. The most erect and Birch graceful tree. It has silvery bark and finely cut foliage. Price: 6 to $8 \mathrm{ft}$., $\$ 3.00$ each. Catalpa Bungeii Top grafted on a tall stem shaped which forms an umbrella for gardens, driveways and parking. Price: $4 \mathbf{f t}$ size, 2 year head, \$1.25 each; $6 \mathrm{ft}$. size 2 year old head, $\mathbf{m e h}, \$ 2.00$.
Mulberry Tea's Weeping. The most graceistence. Price: $2-$ year heads, $\$ 3.00$ each.

Wisconsin (Weeping Willow). A tree with ing a fine lawn tree for a back-ground. It grows very rapidly. Similar to Babylonica but much hardier. Price: 6 to 8 ft. 50c each; 3 for $\$ 1.25$.

NIOBE (Weeping Willow). A very pretty golden bark tree with long drooping slender branches growing in a short time to the ground. Vig: orous grower and perfectly hardy. Price: 6 to $8 \mathrm{ft}$. size $50 \mathrm{c}$; 3 for $\$ 1.25$.

SALIX (Weeping Willow Elegantissima) A vig. orous fast grower, very hardy and a most graceful weeper. Its nature is weeping. Branches very slender. Bright green foliage. Price, per each, 6 to $8 \mathrm{ft}$. $50 \mathrm{c}$. 


\section{ROSES}

\section{Our Rose Department Is a Dream}

We handle nothing but the very hardiest varieties and the very finest bloomers. Many rarieties are too tender for the Northwest. Hothouse roses a re worthless for outdoor planting-ours are field grown, are more easily transplanted, and hardier. Before planting roses cut them back severely. Our stocks of roses are all 2-year No. 1 powerful roots.

Mildew. Use Bordeaux Mixture as long as the disease continues. For Slugs, use Hellebore or Arsenic till destrojed. Lice. Use Kerosene Emulsion, apply until destroyed.

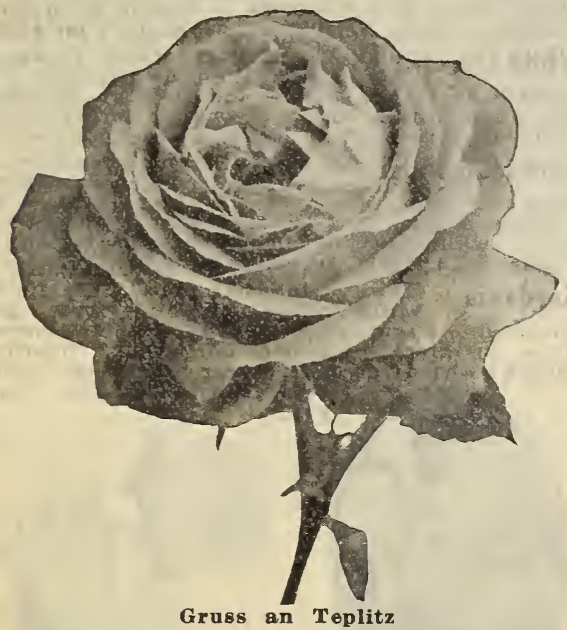

Gruss an Teplitz One of the brightest colored opened, it is a dark, rich crimson, changing to a bright scarlet. Blooms continually; flowers good size and delightfully fragrant. 2-year No. 1 stock, \%5c each; 5 for $\$ 3.50$.

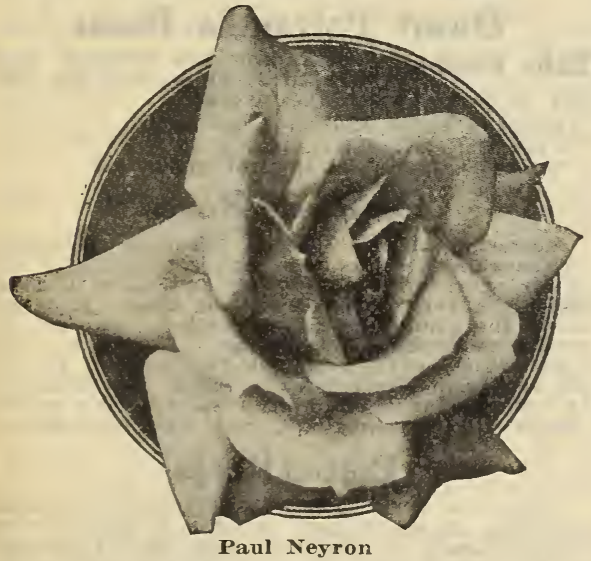

(World's Most Glorious Pink)

Paul Neyron The largest rose in cultivation, Rose. Color bright, tresh, cerise pink. Flowers are very double and full, delightfully fragrant. The plant makes a strong, healthy growth and has clear, glossy follage. Blooms almost without intermission from June until late October. Per each, 2-sear No. 1 stock, 60c; 3 for $\$ 2.00$.

American Beauty The world famous rose. American Beauty Rich, rosy-crimson, exquisitely shaded. A untversal favorite. Not hardy. Price: 2-year No. 1 stock, 75c each.

\section{Hardy Perpetual Roses}

These are hybrids or crosses between June and Monthly roses, partaking of the hardiness of one parent and the perpetual blooming habit of the other.

General Jacqueminot This might be callec lion, for it is still a universal favorite. Bright crimson scarlet, exceedingly rich and velvety Price: 2 year No. 1 h. 3 for $\$ 1.60$.

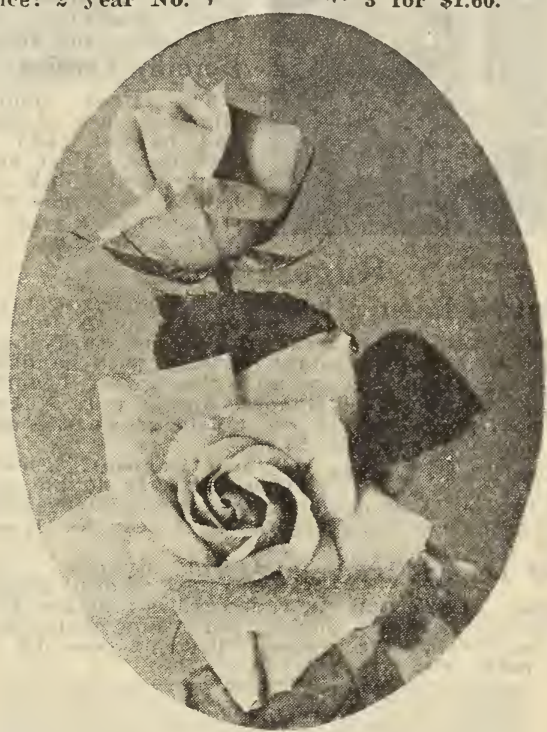

Los Angeles

Los Angeles This is one of the grandest allever put on the market. The stems are as long as American Beauty; the flowers are large as Paul Neyron; its freedom and continuance of bloom are remarkable; its color a "flame pink, toned with coral and shaded with translucent gold at the base of the petals." $\$ 1.00 \mathrm{each}$.

\section{Frau Karl Druschki}

White American Beanty. (Lambert, 1900). This grand rose has become renowned as the very highest type of its class and the best snow-white rose ever introduced. It is an extraordinary grower, and has the vigor and hardiness of an oak. 2-year No. 1 stock, 60c each.

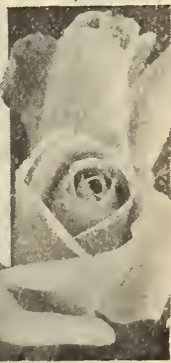

Druschki, White American Beauty Ulrich Brunner A superb rose. Extra large lar; petals large and of good substance. Color rich, glowing cherry scarlet, very fragrant, blooms freely. One of the finest hardy roses. Price: each, 2-year No. 1 stock, 60c; 3 for $\$ 2.00$. 


\section{Ramblers and Climbing Roses}

Climbing American Beauty This variety repink to crimson color and the same delightful fragrance of the bush American Beauty. 2-year. $60 \mathrm{c}$ each.

Rambler Roses

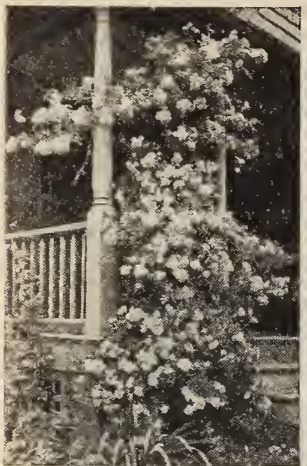

(C. P). This grand old climber hardly needs description. The magnificent trusses of bright crimson flowers are freely produced and admired by everyone. Very hardy and a strong grower. 2-yearold, No. 1 stock, each variety.

Crimson Rambler, 50c White Rambler, 40c. Yellow Rambler, 50c Blue Rambler, 50c. 3 of either for $\$ 1.25$. Dorothy Perkins

The most popular climbing rose of today and hardier than the Ramblers. Most beautiful shell pink and holds a long time without fading. 2-year, $35 \mathrm{c}$ each, 3 for $\$ 1.00$.

\section{Rugosa Roses}

Rugosa Roses (Ramanas). The hardiest rose Northwest. These lovely roses form sturdy bushes 3 to 5 feet in height, covered with handsome glossy, green foliage and clusters of beautiful rragrant flowers. Rugosa, single red; Rugosa, single white. 2-year No. 1 field grown, 35e each, 3 for \$1.00: per doz. \$3.00.

Conrad F. Meyer (Hybrid Rugosa). Flowers large, perfectly double, cupdeep, bright, vivid, intense pink, with a penetrating fragrance. 2-year No. 1, each $75 \mathrm{c}$.

Sir Thomas Lipton (Hybrid Rugosa). The Rose. Strong and vigorous; grows four feet high. Flowers perfectly double, pure snow white, with a penetrating fragrance. Price, 2-year-old No. 1. คคกh. TKr.

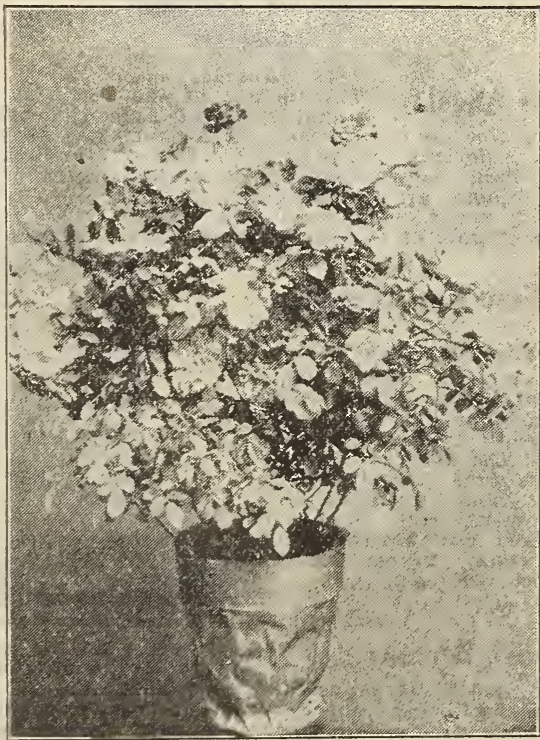

Potted Rose blooming in full foliage
Groostendorst (A new Hybrid Rugosa). Rosa Rugosa Rubra, a cross on Crim. son Baby Rambler; regular Rugosa foliage, bloom. ing character that of the Baby Rambler. Blooms bright crimson flowers in clusters, beginning in May and continuing to bloom all summer until a utumn frosts. An all summer rose. Price 75c ea. Excelsa (Now). (Red Dorothy). The color is axcelsa an intense clear crimson, with tips of the petals tinged with scarlet. Grows 10 feet in a season. Flowers are large and double and almost every eye produces a cluster of bright blossoms. 2-year No. 1 stock, 50c each; 3 for $\$ 1.25$. White Dorothy A beautiful white flowered White Dorothy cluster Rose, as free and ex. pressive as its pink rival, the Dorothy Perkins. The vines are a sheet of white during their blooming season. 2-year No. 1 stock, 35c each. American Pillar A single-flowering variety of Areat beauty which appeals to re of large size, 3 to 4 inches across, of a lovely shade of pink, with a clear white eye and cluster of yellow stamens. 2 year No. 1 stock, 50 e each; 2 for $90 c$.

Gardenia (Hardy Marechal Neil). The finest hardy yellow climbing rose jet produced. Deep, rich golden yellow; flowers borne in great profusion on strong, vigorous bushes as hardy as oaks. 3-year Star stock, hardy tield grown, each, 50c; 3 for $\$ 1.25$.

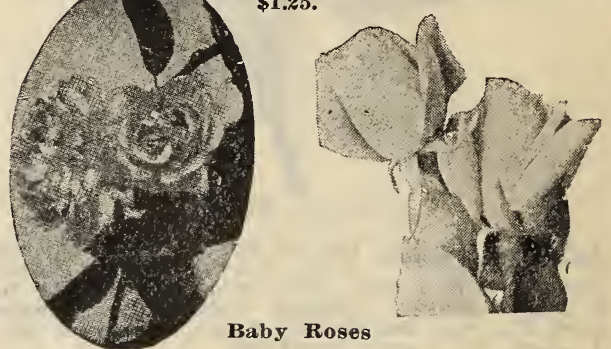

Dwarf Polyantha Roses

Baby Rambler The flowers are borne in clusters to 30 or 40 , and the foliage is dark, glossy and profuse.

Crimson Baby Rambler, 60c each.

Pink Baby Rambler, 3 for $\$ 1.50$.

White Baby Rambler, 3 for $\$ 1.50$.

\section{Cemetery Roses}

Memorial White Rose, Mandy's Triumph. (Wichuraina). This rose makes a beautiful and enduring covering for graves and plots in cemeteries. A very hardy Memorial Rose. It creeps along the ground as closely as Ivy. Flowers are produced in lavish profusion. They are single pure white, with a golden-yellow disc, five to six inches in circumference. It is also immensely valuable as a climbing rose, covering arches, fences, etc. 2-year No. 1 , each 50c; 3 for $\$ 1.25$.

\section{Potted Roses}

These are such varieties as Hybrid Perpetuals and Tea Roses 2 year old No. 1 Field Grown Stock, potted in February and started growing in the greenhouse. They are in full follage and ready to plant out in the Spring when weather conditions are such that they can be planted outdoors from about the 1st to 10 th of May at earliest. They will then continue to bloom all through the Summer and Fall.

Would also include in these Potted Roses in foliage the well known Crimson Rambler, one of the best and most popular climbers, and among the others is the well known American Beauty, Paul Neyron, Gruss an Teplitz, Ophelia, Los Anreles and others. Price: grown in 5 inch pots, $\$ 1.50$ each; 6 inch potted size, $\$ 2.00$ each. Special price in dozen lots. 


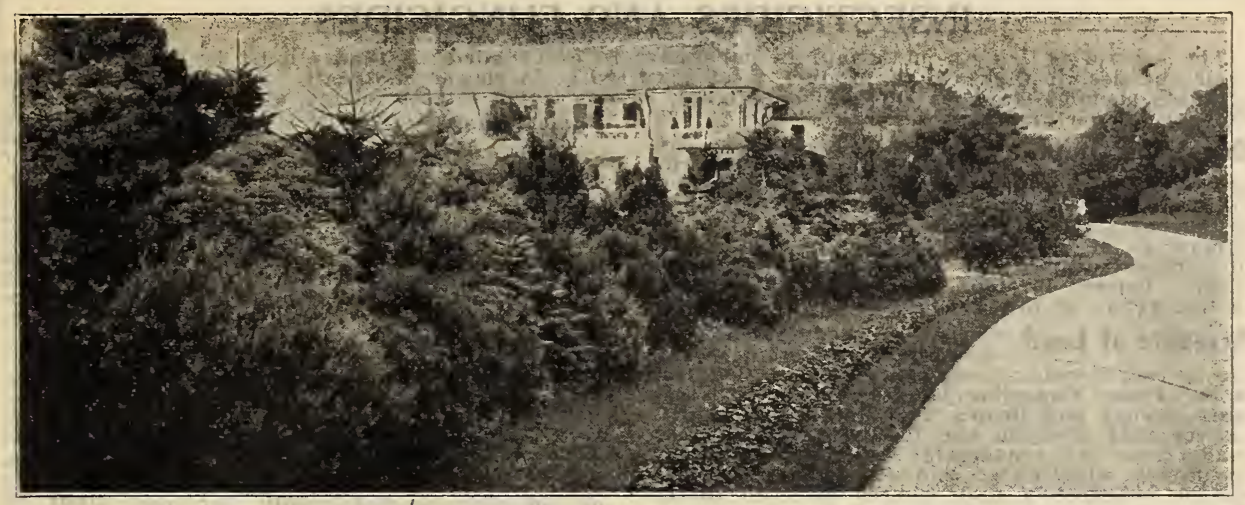

An Evergreen Planting Which Appeals to Our Love of the Home Beautiful

\section{HARDY EVERGREENS}

Evergreens give a cheerful appearance to a home. If properly handled, taken up with ball of earth are as sure to live and grow as deciduous trees. We list only such varieties as are found to do the best here in this soil and climate. See special prices in large quantities seedlings and transplanted stock given below.

The term "B \& B" used in these descriptions means dug up with "ball of dirt" and "burlapped."

ORNAMENTAL STOCK

Specimen Trees

Black Hills Spruce (Picea Alba). This has for many generations. It is admirably equipped for the Western prairies, easily transplanted and altogether it is very desirable for the general planter. Specimen trees dug with ball dirt burlapped, 2 to $21 / 2$ ft. $\$ 2.25$; pair for $\$ 1.00 ; 21 / 2$ to 3 ft., \$2.75; per pair, $\$ 5.00$.

Colorado Blue Spruce (Picea Pungens). It and endures well the sun and drying winds. The needle is very sharp pointed and varies in color from a delightful green to a deep blue. Specimen trees, select blue, $B \&$ B, 2 to $3 \mathrm{ft}$., each, \$6.00; per pair, matched, $\$ 10.00$; select green 2 to $3 \mathrm{ft.}$ \$ $\$ 1.00$ each.

Blue Spruce (Koster Grafted). Other trees Blue there are of almost every imaginable color and form, but here is truly the cul- mination of Nature's bighest effort to proảuce the beautiful. Specimen trees, B. $\&$ B. 3 to $4 \mathrm{ft}$. $\$ 15.00$ each.

Mugho Pine (Dwarf). Very distinct, leaves thickly distributed over the branches; does not grow tall but has a dense spreading form. Per each, diameter measure $1 \frac{1}{2}$ feet, $B$ \& $B, \$ 2.00$ each: 2 to $3 \mathrm{ft}$., $\$ 3.50$.

Arbor Vitae Pyramidalis. This exceedingly and erect of the entire species. Foliage a deep green. Specimen trees, 2 to $3 \mathrm{ft}$., B. \& B., $\$ 3.50$ exch; 3 to $31 / 2$ ft., $\$ 5.00$.

Red Cedar (Juniper Virginiana). The well Cedar known American Red Cedar, varying some in habit and color of foliage, well sheared conical. Specimen trees. 2 to $3 \mathrm{ft}$. B \& B. \$2.50 each; 3 to 4 feet, each \$4.00.

\section{Evergreen Seedlings}

Transplanted Nursery grown stock and Forest Grown Stock.

BIACK HILLS SPRUCE-This variety of (Picea Alba), has come to stay as a great wind-break Evergreen for the North and all exposed locations. Easiest and safest to transplant of all Evergreens. Most certain to live. Native Forest grown from the Black Hills, 12 to 18 inch size (shipping weight about 25 lbs.) $\$ 5.00$ per 100 . 18 to 24 inch (shipping weiglit about 401 bs.) $\$ 7.50$ per 100 . f. o. b. Black Hills points in South Dakota. Sold only in 100 lots. Nursery grown stock seedlings, 6 to 8 inch, $\$ 7.50$ per 100 . Nursery grown transplanted stock 12 to 18 inch, $\$ 70.00$ per 100 . 18 to 24 inch. \$109.(6) per 100

COLORAdo BLCE SPRUCE (Picea Pungens) The glory of the Colorado Blue Spruce surpasses all other evergreens. Its bewitching, fairy- like, intense beautiful blue commands the admiration of all who behold it. In winter as well as summer its halo of azure is ever the same. Other evergreens sometimes fade and bronze in the winter and then freshen again in the spring but this is not true of the Colorado Blue. It is as constant in color as the hearens above it. What we offer in all seedlings of this Spruce are native Colorado forest grown stock from the sections in the mountains of their nativity. They are well packed in moist mountain mass for express shipment. One hundred of these seedlings will soon make a nice block of evergreens and with fair treatment you will get at least 80 to $90 \%$ of them to grow and possibly all of them. Price F. O. B. Colorado growing station. 6 to 12 inch size, 25 for $\$ 6.00 ; 50$ for $\$ 10.00$ and $\$ 18.00$ per 100 . 12 to 18 inch size, 25 for $\$ 10.00 ; 50$ for $\$ 18.00$ and $\$ 30.00$ per 100 .

JACK PINE (Pinus Diviaricata). The most northern of all American Pines. Extremely hardy and vigorous, withstanding long droughts and hot, dry winds. Of rather irregular growth. Fol iage bright green needles short and stiff. For a windbreak it should be planted closer than the Scotch Pine. Nursery grown seedlings, 8 to 10 inch, $\$ 7.00$ per 100 . Nursery grown transplanterl stock 18 to 24 inch $\$ 17.50$ per 100. 


\section{INSECTICIDES AND FUNGICIDES}

The control of insects and fungi is imperative in every garden. Plants must be protected from their enemies, if they are to produce most luxuriantly in flower and fruit. There are three kinds of these enemies-fungous diseases or blights, insects which eat the foliage, and insects which suck the sap of the plants.

Dry Lime Sulphur Best remedy for San Jose use early in the season before the foliage puts out on fruit trees and berry bushes; mix one part to ten parts water. Also one of the best summer sprays as an excellent fungicide. When used in summer dilute with twenty to thirty parts water. Prices: 1b. pkg., 25e each; 5 lbs. \$1.00; 10 lbs. \$1.75; 20 lbs. \$3.00.

Arsenate of Lead Dried powder Arsenate of ing or leaf chewing insects such as the Coddling Moth, Plum Curculio, Canker Worm, Tussock Moth, Gypsy and Brown Tail Moths, and similar insects that feed on the foliage of fruit trees, shade trees and ornamental shrubbery. It readily mixes with water and stays in suspension almost indefinitely and insures an even distribution of the poison. Price: 1 lb. pkg., 50c each. Hammond Slugshot Guaranteed to destroy potatoes, tomatoes, egg-plant, also currant worms, cabbage lice, and cabbage worms. I lb. package, 25c; 5 lbs., $\$ 1.00$.

Tobacco Dust One of the best remedies for Tobacco Dust green and black aphis. fleas, beetles, etc., also for insects in the ground. $\mathbf{L b}$. 15e; 5 lbs. 35c; 10 lbs. 60c; 100 lbs. $\$ 5.00$.

Bordeaux Mixture The best fungicide for currot, mildew and blight. Price: lb., 40e; 3 lbs $\$ 1$. Nicotine Sulphate "Black Lear" $40 "$ is a contine sulphate, guaranteed to contain 40 per cent nicotine by weight. It is a contact insecticide. Mix 1-oz. bottle with 8 gallons of water. Price: Per oz. bottle 35c: $1 / 2$ lb. can, $\$ 1.25$.

Paris Green Our Paris Green is absolutely pure State and National laws. Put up in sift-proof packages. $1 / 4$ lb., $1 / 2$ lb.. 1 lb., 2 lb., and $5 \mathrm{lb}$. cartons. Prices on application.

Tree Tanglefoot A perfect safeguard for trees Gypsy, Brown Tail against the Caterpillar of the Canker Worms, Cut Worms, Ants and other creeping insects. Will remain sticky about three months when fully exposed to the weather. Price: 1 lb. rans 50c each.

Bug Death A nou poisonous c h e mic a l composition for use oll currants. truck, generally prevents blight. Price, 1b. 25c.

Tree Treatment Tree Surgery. There is a preIree Ireatment pared compound now in use for tree surgery called " 43 for the tree," that is of plastic material, ready for use, light in weight, contains those acids that destroy fungii and insects and medicinal oils that will penetrate, absolutely waterproof and sets quickly. Price, one pound cans, 65c.

Garden Guard "Guards Your Garden". Garden Guard is effective against many of the chewing insects that prey upon house and garden plants, shrubs, vines, melons, tomatoes, cabbages, currants, vegetables and flowers.

A convenient and economical garden insecticide and fungicide ready for use as it comes in the package. Price per can, 25c.

Two-Way Spray "Insecticide and Fungicide." nation spray for combating chewing insects and fungus diseases in one application. Can be applied as a dust without fuss or mixing as well as in a liquid spray if desired. Price per can, 25c.

\section{CARBOLA}

CARBOLA is a white paint and powerful dislufectant combined in powder form. It paints and disinfects in one operation and it can be applied with a brush or spray pump to wood, brick, stone. cement, plaster board, etc., and over whitewash.

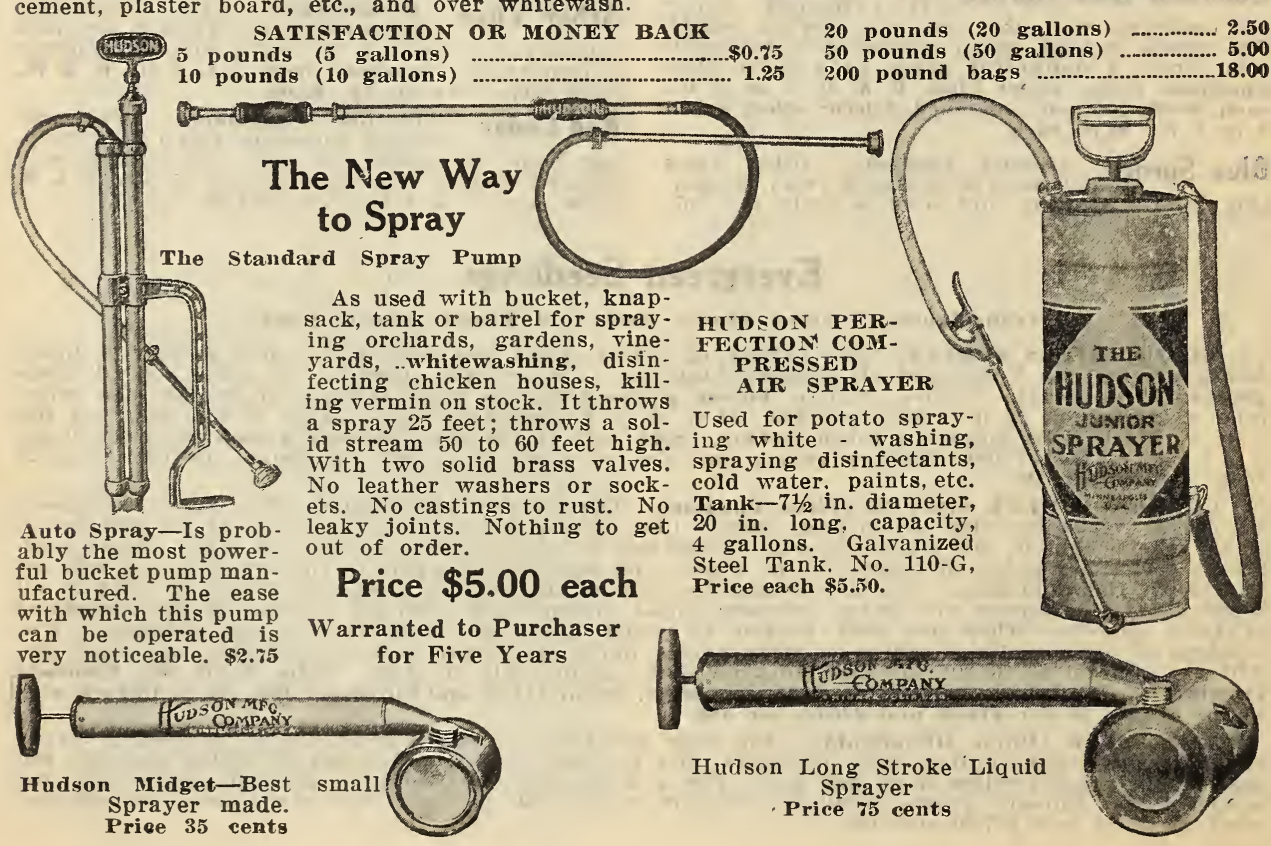




\section{FERTILIZERS}

For the intensive cultivation of plants in the home garden or grounds, fertilizers play a very important part. The following fertilizers represent the best for the home garden and the lawn. All prices subject to market changes.

Prices quoted are F. O. B. depot or delivered in city within delivery distance.

Sheep Manure A pure, natural manure that ed directly in the hills or drills with the seed. it promotes a rapid and steady growth until maturity. On lawns well raked in either springtime or fall adds wonderfully to the growth of the grass, 100 lbs. to about $2500 \mathrm{sq}$. ft. It makes the richest, safest and best liquid manure. For use in liquid förm, $1 \mathrm{lb}$. of the material to 5 gallons of water will make a liquid that can be used daily with safety. 5 lbs., 25c; 25 lbs.. \$1.00; 100 lbs., \$2.50; 500 lbs., \$12.00; ton, $\$ 35.00$.

Bone (Fine Ground). For use by the vegetable the market. It has been steamed to soften same and is quick to act. For trees or vines use 2 to 4 lbs. About 5 ibs. for 100 square feet for starting a new lawn. Per lb., 10c; 3 lbs., 25c; 100 lbs. \$4.50; 500 lbs. \$17.50.

Stim-U-Plant Comes in tablet form and contains highly concentrated plant food in immediately available form, stimulating the growth of flowers, vegetables, fruit and the ornamental plants. Full description with each package. Trial size, 10 tablets, 15c; medium size, 30 tablets, 25c; 100 tablets, 75c; 1,000 tablets, $\$ 3.50$.

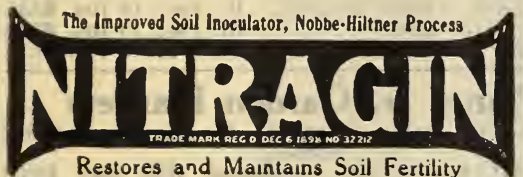

Restores and Maıntaıns Soil Fertility

Alfalfa, clovers, soy beans, vetches, always be inoculated with Nitragin. The of a poor legume crop-a weak start-or a total failure.

Nitragin is an old, reliable inoculator. At the low price of 20 to 33 cents per acre you cannot afford to sow legumes without it. Nitragin is put up in the modern ventilated package; in a rich, soil-like packing medium. The contents are always fresh, living bacteria to feed your plants. Easy to use.

\section{USPULUN-Seed Disinfectant}

LSPLLUN is a seed and soil disinfectant that prevents soil decay. blight on plants, smut and other diseases that come from the soil and are transmitted in the seed by disinfecting first the seed and then also applying it to the soil, but mainly for disinfecting the seed. bulbs and plants. Seed so treated permit earlier planting and stronger germination and more vigorous plants of greater yield and better quality. Poisonous to animal life but harmless to plant life.

A pamphlet with full description and how to apply it and quantity to be used furnished with each can. Prices Uspulun as follows: 5 lb. tins, per lb. $\$ 2.60 ; 25$ and 50 lbs. (in bulk) $\$ 2.50$ per 1 b. or more. $\$ 2.35$ per $1 b . ; 2$ oz. tins 50 ; 8 oz. tins $\$ 1.60 ; 1$ lb. tins $\$ 2.75$ per $1 b$.

DIPDUST-4 ounces 50c; 1 pound, \$1.75; 5 BAYER DUST-(Dust Treatment)-4 ounces pounds, $\$ 8.00$. 50e; 1 pound, $\$ 1.75 ; 5$ pounds, $\$ 8.00$.

\section{SEMESAN - The Modern Disinfectant for Seeds, Bulbs, Plants and Soils} SIMILAR TO USPULUN.

Applier in either its original dust form or as a liquid, Semesan effectively destroys all disease germs and parasitic fungous spores. Moreover, it aids in preventing contamination from disease infested soils and actually accelerates germination. While extremely toxic to disease and fungoid growth, it is harmless to plant life. Prices: Semesan is sold in a complete variety of package sizes at the following prices: 2 ozs. 50c; 8 ozs. $\$ 1.60 ; 1$ lb. $\$ 2.75 ; 5$ lbs. $\$ 13.00 ; 25$ lbs. $\$ 62.50 ; 501$ bs. $\$ 122.50$. The prices for both Semesan Bel and Semesan Jr. are: 1 1b. $\$ 1.75 ; 51 b 8$. \$8.00; 251 lbs. $\$ 37.50$.

\section{SOILTEX}

SOILTEX-This is a chemical preparation put up for the purpose of testing the soil to find out condition of same and to know definitely what may be expected in the way of a crop from the test directly from the field. Every portion of the field should be tested once ill a while, including even the sub-soil. Alfalfa and other crops often fail because of a lack of some needed chemical in the soil. Soiltex is the thing to do it with and the test is very siniple. No technical knowledge or apparatus required. Pocket size outfit makes 75 to 100 test. Price per out fit, \$1.00. 


\section{POULTRY SUPPLIES}

\section{ALL PRICES ON POULTRY AND ANIMAL FOODS SUBJECT TO CHANGE}

\section{Our Poultry Foods Are All Foods-No Waste, Always the Same}

Starter (For the Little Fellows.) ... Is a comsmall chicks two days to two weeks old, adapted to their delicate digestive organs 6 lbs., 25c; 50 lbs. $\$ 1.75 ; 100$ lbs. $\$ 3.25$.

Eureka This is a food intermediate between the Cureka Starter and the Acme Scratching Food. (For chicks from two weeks to two months old). 6 lbs. 25e; 50 lbs. $\$ 1.25 ; 100$ lbs. \$3.25.

Acme (Scratch Food). Combination of Wheat, Acme Kaffir, Cracked Corn and various other rich cereals. All food and no waste. 6 lbs. 25c; 100 lbs. $\$ 3.00$.

\section{PRATTS PRODUCTS}

PRATTS BUTTERMILK BABY CHICK FOOD

Made of sweet, wholesome, purest ingredients in the most modern poultry feed mill in America and mechanically predigested, it is life insurance for chicks. Every ounce is full of bone, muscle, feather and health builders. You'll pay for the food in the chicks you'll save.

Equally good for young turkeys, guineas, ducks, pheasants and game birds. A perfect "baby food" for young fowls.

50c packages and 14, 25, 50 and 100-1b. bags. lb. bags.

\section{BLATCHFORD'S PRODUCTS}

FALFA MEAL furnishes the green food that 作 , 25c; 100-1b. bags, \$2.75.

most commonly used articles in poultry of the Price: 15 lbs. 25e; 100 lbs. $\$ 1.35$.

CHARCOAL. Most sucressful poultry raisers teed this soft with food. 3 lbs. 25c; 10 lbs. 60c.

MICA GRIT. Fowls have no teeth, so it is essential that they should have grit. 100 lbs., $\$ 1.35$.

Pratts Poultry Regulator 25e, 50c, \$1.10 packages; 12 1b. pail, Pratts Powdered Lice Killer In sifter top cans Pratts Condition Tablets Keep them on hand 50c boxes

Pratts Roup Tablets 25e and 50c packages.

Pratts Poultry Disinfectant Qt. 55c; half gal., 90c; gallon, \$1.50.
Calf Meal Price: $25 \mathrm{lb}$ bag, $\$ 1.50 ; 50 \mathrm{lbs}$. \$2.75; Egg Mash This is a genuine Egg Food for layfor \$5.00.

Pig Meal Milk substitute. 25 1b. bag, \$1.35; Blatchford's Chick Mash The ideal food for excellent for growing chickens. 25 lb. sacks, $\$ 1.50$; per 100 lbs. $\$ 5.50$.

\section{ANIMAL POULTRY FOODS} 5 lbs. 25c; 100 lbs. \$4.50.

Blood Meal It will make hens lay during 25c; 10 lbs. 75c.

Beef Scraps (Granulated Protein 60 to 65 per lbs. \$5.50.

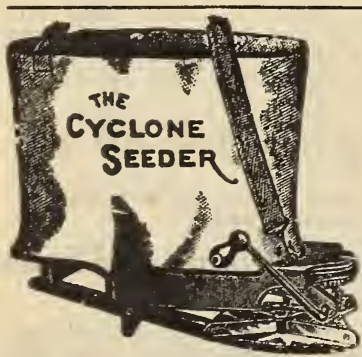

Bone (Coarse ground for poultry). Lb. 10c;

\section{BIRD SEED}

Canary seed, extra, recleaned, lb. 15c; 10 1bs. $\$ 1.25$ Hemp seed, extra, recleaned, lb. $15 \mathrm{c} ; 10$ lbs. $\$ 1.00$ Rape seed, (Bird Rape).........lb. 15c; 10 lbs. \$1.25 Mixed Bird Seed …................... 1b. 15c; 10 lbs. $\$ 1.25$ Sunflower Seed, large, fresh....lb. 15c; 10 lbs. $\$ 1.25$

\section{Planet Jr. Garden Planters}

Special Cut Price. Subject to change without

No. 4D Planet Jr. Combined Hill and Drill Seeder. As seeder only, $\$ 14.00$, complete $\$ 18.00$ each.

No. 25 Planet Jr. Combined Hill and Drill Seeder, Double Wheel Hoe. Cultivator and Plow. $\$ 21.00$ each. Weight, packed, 61 pounds.

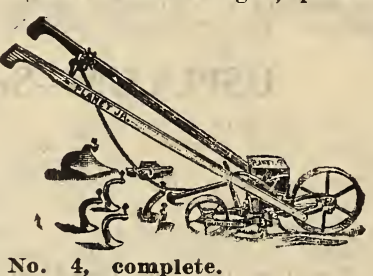

Planet Jr. No. 4, complete.

Magic Hand Weeder

Handiest Tool on Earth. Per each, 30c.

\section{Cyclone Seeders}

It is especially designed for distributing venly all kinds of grain as well as every variety of grass seed. Price: \$2.50.

\section{Forest Tree Seedlings}

All orders for River Forest Grown Tree Seedlings booked subject to unavoidable Providential happenings such as forest fres, floods, strikes and weather conditions over which we have no control.

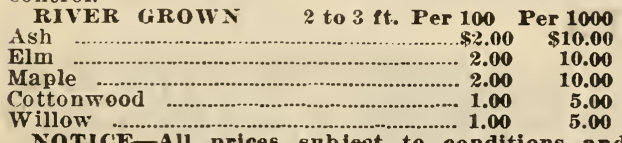

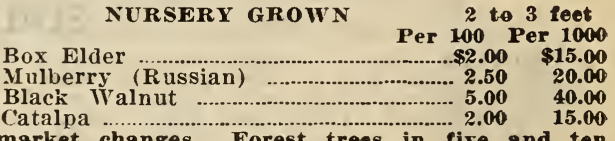

NOTICE-All prices subject to conditions and market changes. Forest trees in five and ten thousand lots, special prices on application. 
